大磨府兵覀時代の隔結兵に就いて

家

の 團

兵 結

に度

入. 磨

り 代

r k

の 發

統 達

轄 し 言

に E

官 兵

兵で

の あ

補分

助但

L L

$\tau$ 鄉

使 村

用 黑

せ 䦓

b 㕸

れ自

を橖

官・の

兵 凨

的

占

兵自

でら

あ 主

る 骾

府应

兵 2

制て

度 結

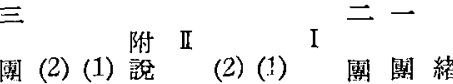

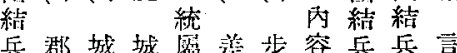

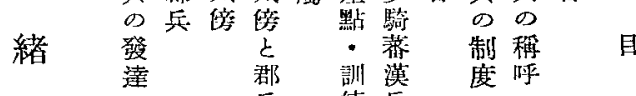

目

K

綀 兵 概

組附晸

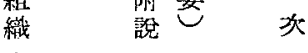

居

府

兵

待城

満倍

筫忘

制

箁兵

時

職

f

任

の

衣

團

䜽

紜

兵

に

憱

狳 I 1 四

四 III II I

橉 (3) (2) (1)

言城国結制兵地

倍結兵图城䔨度貝域

の兵の結倿土の數的

出

現創原的成衙展晢及

年喵出立の段加

代年 現純階概

が 成

份 乙

兵

日

野

行 祀

は純

况民

$\tau$ 兵

みで

をは

時 無

代 ?

已國

開

三

郎 


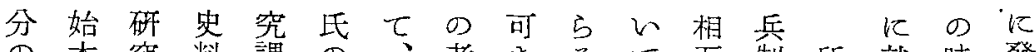
进 の本究料課 D 考 きる

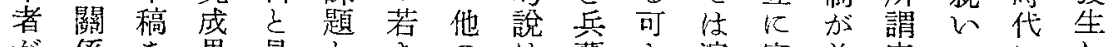
が係を果見とききの募き濱密並府てにし、

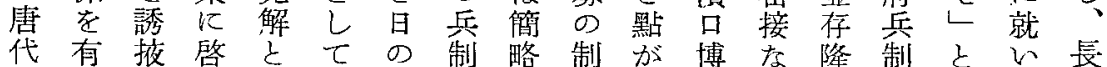

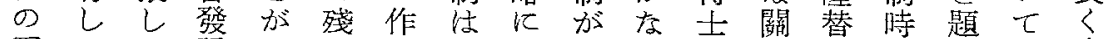
霜てた 誘示さで此失全いの係し 代し考唐

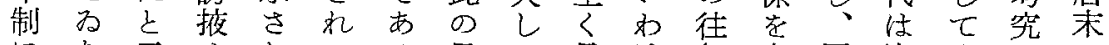

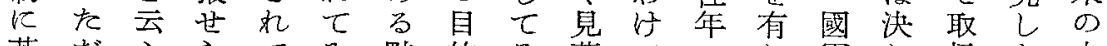
若だふらて わ點的と落でのし軍し极た 大

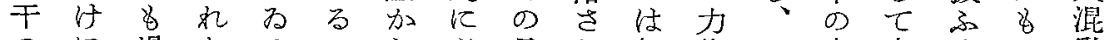

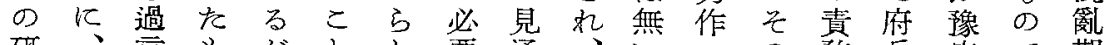

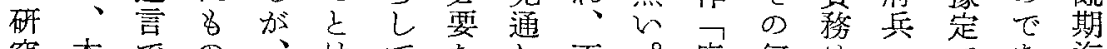

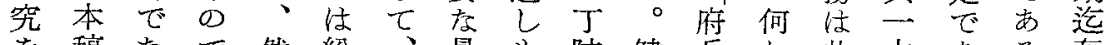
を稿なで然紛、最8 防健兵れ此本古る存

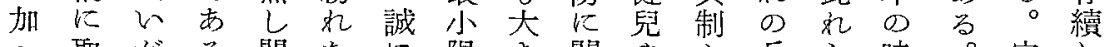

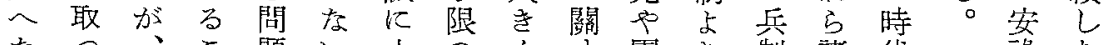
た 己

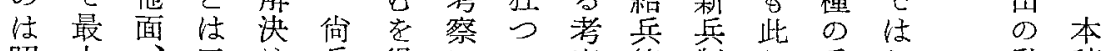

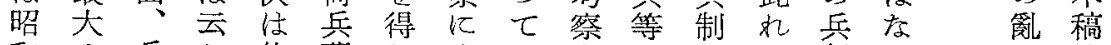

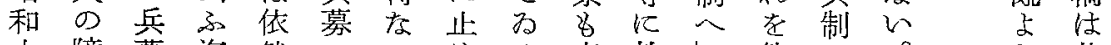

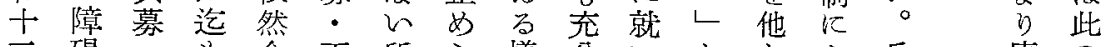

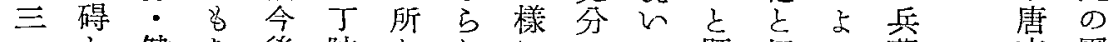

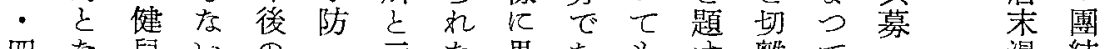

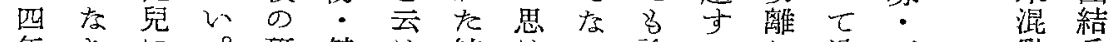
年りに研健は結はW論るるし逐丁 简兵

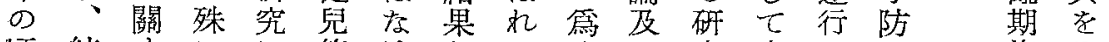

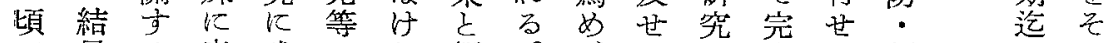

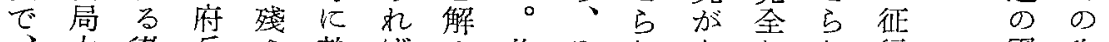

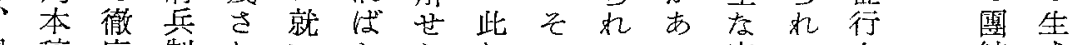

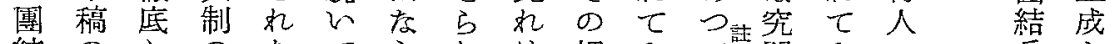

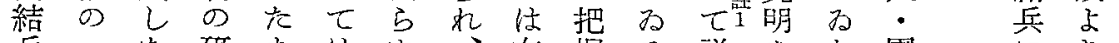
兵一皇研まは炡右握る詳をた 史大研究ま故が又論が肪細成。結就安 料弱究成で王、此文正、にし從兵祿

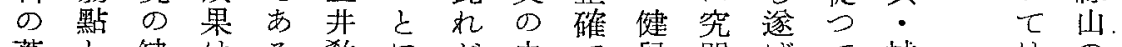

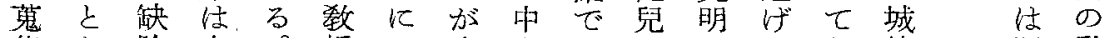
集索除本。授が卒心なに学此傍 别亂 $8 つ$ は稿本のく業目少就方こ れ

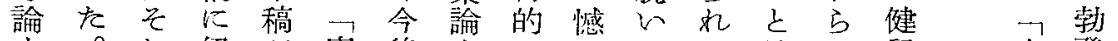

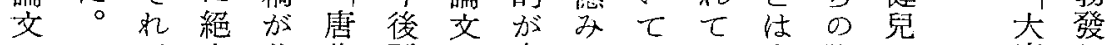
の が大此代更に府がはわ出諸・居し

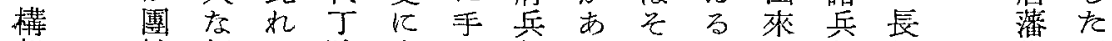

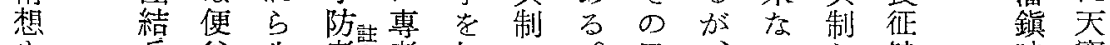
8 兵益先考若加の 。 母 、

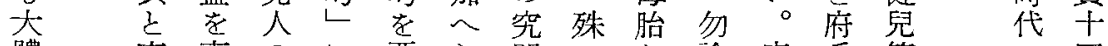
體淁惠 $の に$ 要 $ら$ 明にと諭府兵等

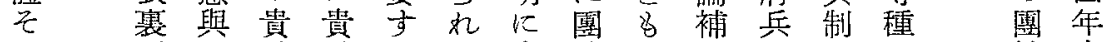
丕し重 重るた在結云正にと令結末

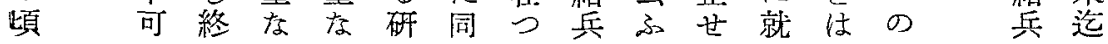




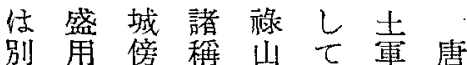

飞 等 呼のの團代

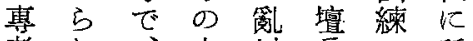

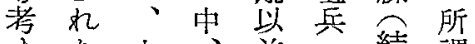

与た士府前

る 稱 電府 兵壇

心呼睩兵交丁士結

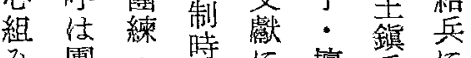

み雪・時に壇兵に

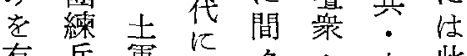

有兵電用\&政

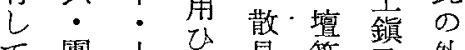

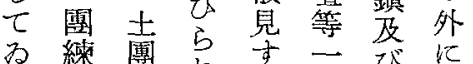

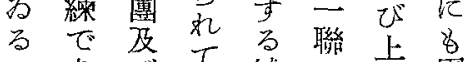

のあでて 城

たる。壇た 傍壇逃䋱

此安含

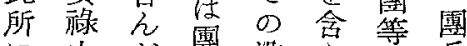

に山だ結沿ん. 一兵

は の一繥革 だ聯・

詳縭聯兵や稱势 團

細以 $匚$ 围性呼士結

略 の 呼結前名字字

高㩐 等 團於り、含 練

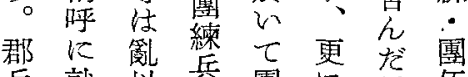

兵就以兵團に䊈伍

城七 後團結都呼

傍は文練市を学.

に裳 獻團類以市士

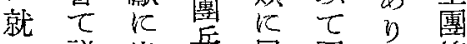

詳出兵屬團、等

七諭現闻方結 又一

はしし荳る兵四聯

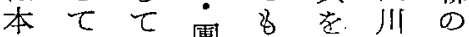

稿居势罚 $の$ 指文團

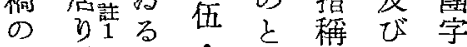

後、。解し之を

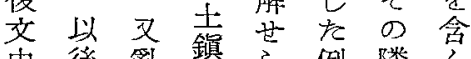

中後敛鎮方例隣台

に 0 の 兵好的接代

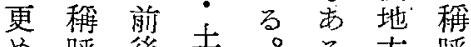

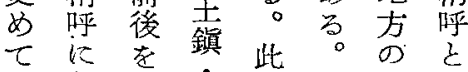

訧就通郡机別方 声
註 $\begin{gathered}\text { 口 } \\ 0\end{gathered}$ 於

$I \longrightarrow$ 然 $D \tau$ 募 $D$ L

史是近艺出來门市殆

雜早出暂方防方九

点く將く限夜 が ど

一次手簡兒再五

篇汃此許略等檢年

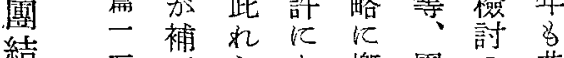

結 - 正 ら市概 團 の昔

兵 $\quad$ - をのり說結氣の

の 二 加諸市し 兵力こ

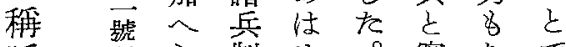

呼所方制毕。泌なで

○收れをた然接くあ

九專劣8 点兄る

こ若數此關 の

を究史概を衣の

切之料 說有に後

望てかたし本ち

乙弱ら る

七 點手やら召

已 $の$ 取、然 組

变補 り 充名九 敗

正早分别坮戰

2 次をく存個蹯・

第早組 象に瀬疎

同忍急み料詳放開

博

士る試蒐せ本の

安。攵集ら稿混

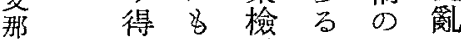

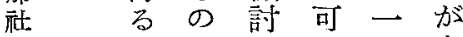

會裕でのき大あ

經り り大弱つ

濟 は筆に笘て

史無者立店で蒐

研至のつ間あ集

究見詳題る象

所引當破は。料

收で程庄本们

あ度研稿当

る。 究に

幸分果要紛

にがを应失

篤少要 範常

學く約圍生

の索しにじ 


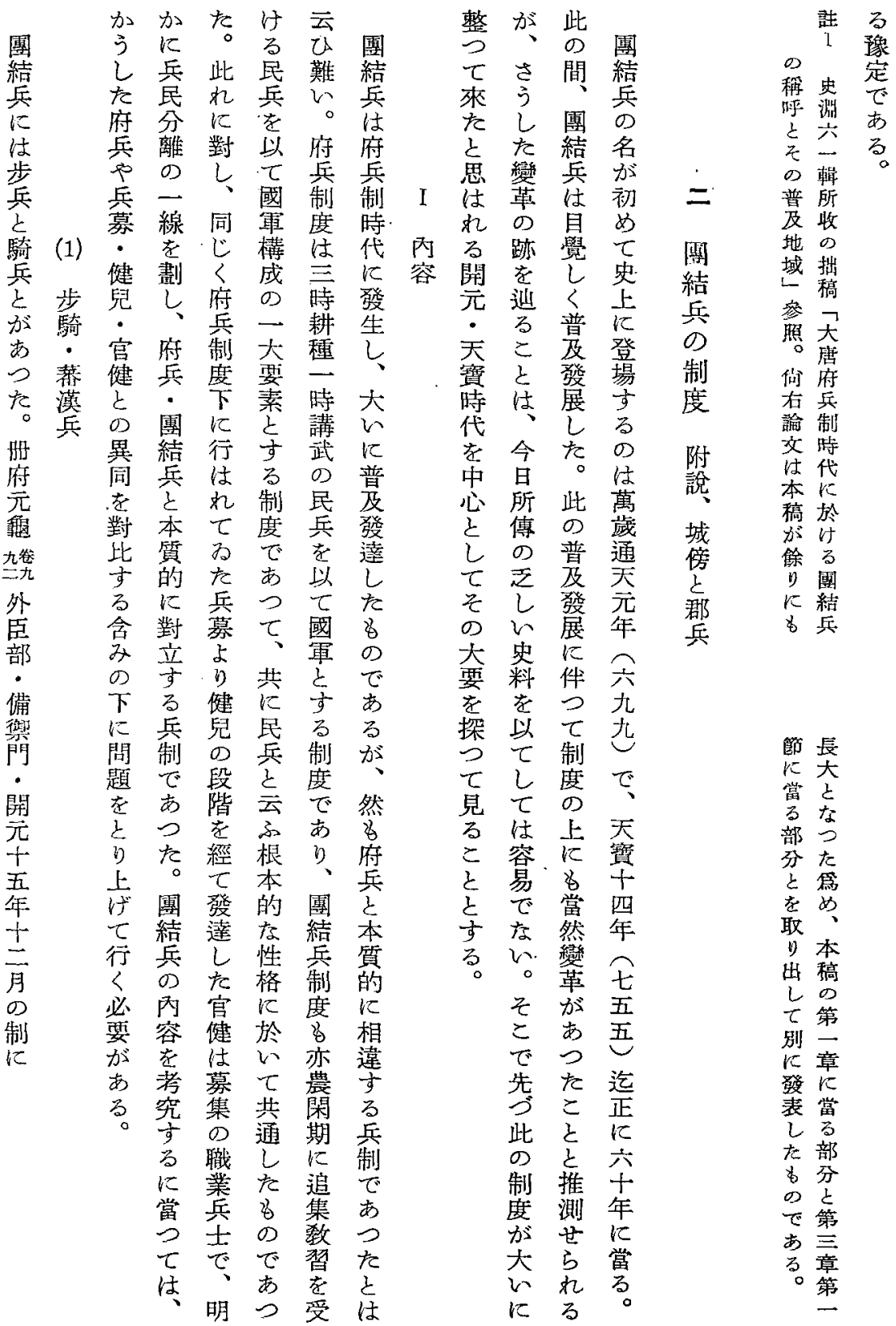


大唐府兵制時代の團結兵に就いて

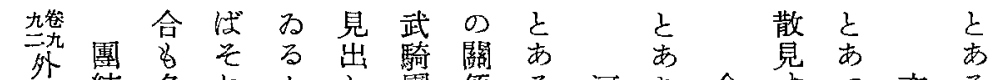

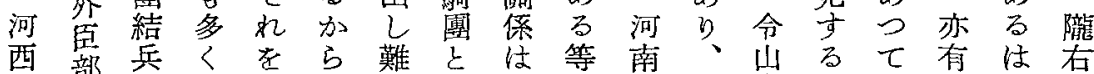
酉道 部 兵々、炎

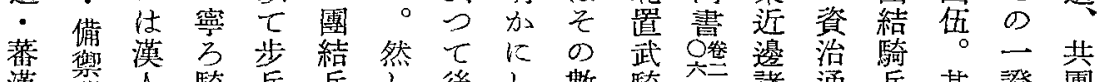
漢 鬥 人 騎兵兵

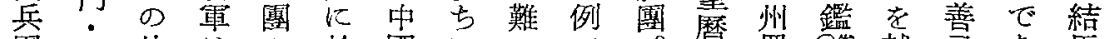

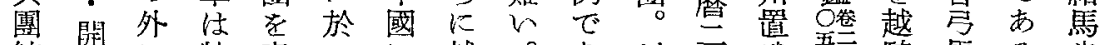

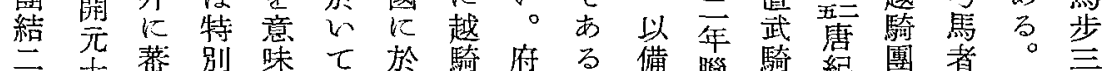
萬 五 人 扱 $L$ 莱

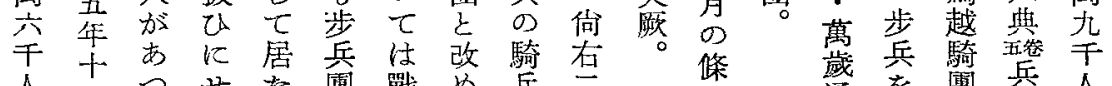

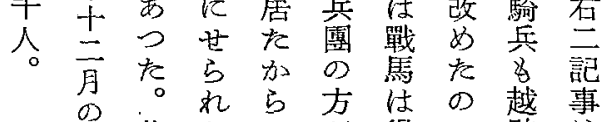
の 此をれ ら

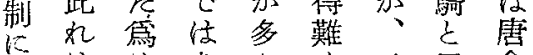
はめ あ かく 二云會 府武るつ、样 つ 要 兵騎また鳻 のて 八管 や量いでめ稱る无 健のか市に㭔る諸 兒用。ら歴を少使

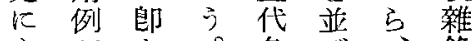
8 が 5 。各び、錄 見却葍步種用越の

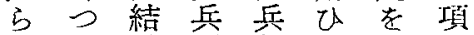
れて 兵嘼制て武に る多とななる なる 所く云る通た覃收 で散へ䊈じ魚め

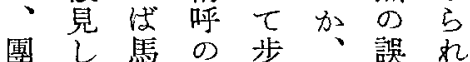

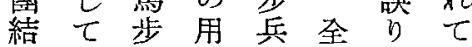
に

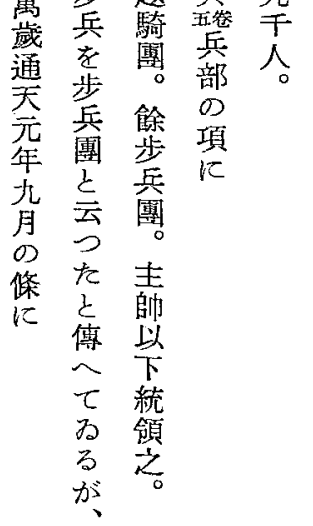

兵わを例がくとる

のる 總㤎騎制はる

み 0 括少兵方云。

のですい吉存へ越

こあるのりいな騎

とらとは多。い灀 で。共、い步㦈文 任。に單 0 兵江武 越 無步にが團思騎 心 兵團通 $\sigma$ は團 。團結 例用れと

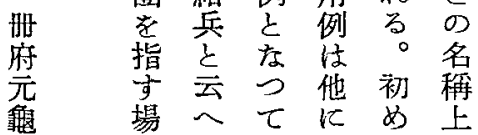

見

無

武
騎
團
の
䊩
呼
が 
ま 㐬

己百 姓 差

差名鶋古

の團 臬

對 練 八等

象春諸 夏

士秋使 農

人䟿 錄

- 终録秋

百夏同冬

姓追年虽

存集同集

与 月 紷

云給十答

ひ一百

、身條嶈

文糧保燥

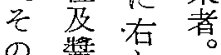

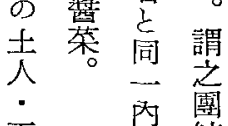

百容 結

姓白

が 殆記

殆碀

え゙学

产隹

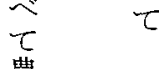

條此水若

に (亿) の た午圄 方所 0 結

差針以厓 兵

點にと異に

8 乙が監

拘て あ步

團 500 .

結ず共た愣

兵、通筈漢

の史的艺の

民料疗市别

兵 08 名

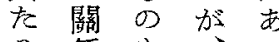

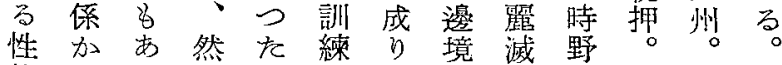

格らつし以. の地它に每有六

は漢を文上組此區の在年高典

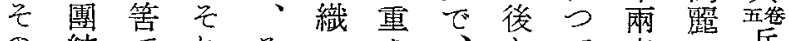

の結でれそ!をを艺て度・兵

差兵あらの待有所此緩呚美部

點 の る 馬差遇し謂の意練兵项

に考。步點・而地に使。項

明說 團蕃 ・負当漠方 應知

確に結 漢訓据古雜に召部

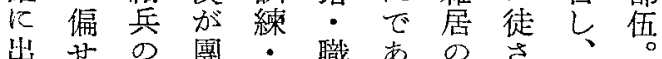

ざ性結 待任ら地れ州如

わる格兵遇と方でてに有

るをとを・戰。市子統警

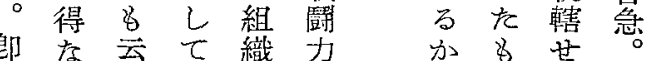

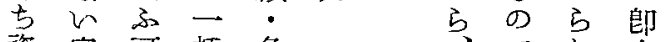

資 實 可括 負

治情きせ擔

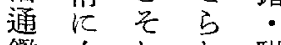

鑑在礼犯職

五篦省府等

唐通兵に

紀的户就

- 兵

大諸 募 乙

曆點 - 安

十齐健

二 考兒机

年 說 等 ぞ

五立文和

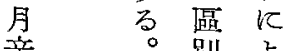

辛別ま

の ᄂ 5 工
蕃あて赴

結るする 援

兵團 $\infty$

8 結 で

河 兵 あ

西のる

- 普方

㒕 及

右し 團

二 $\tau$ 結

道わ 兵

に

限 所 類

ら河屬

₹北 $\frac{\text { के }}{\text { ? }}$ 


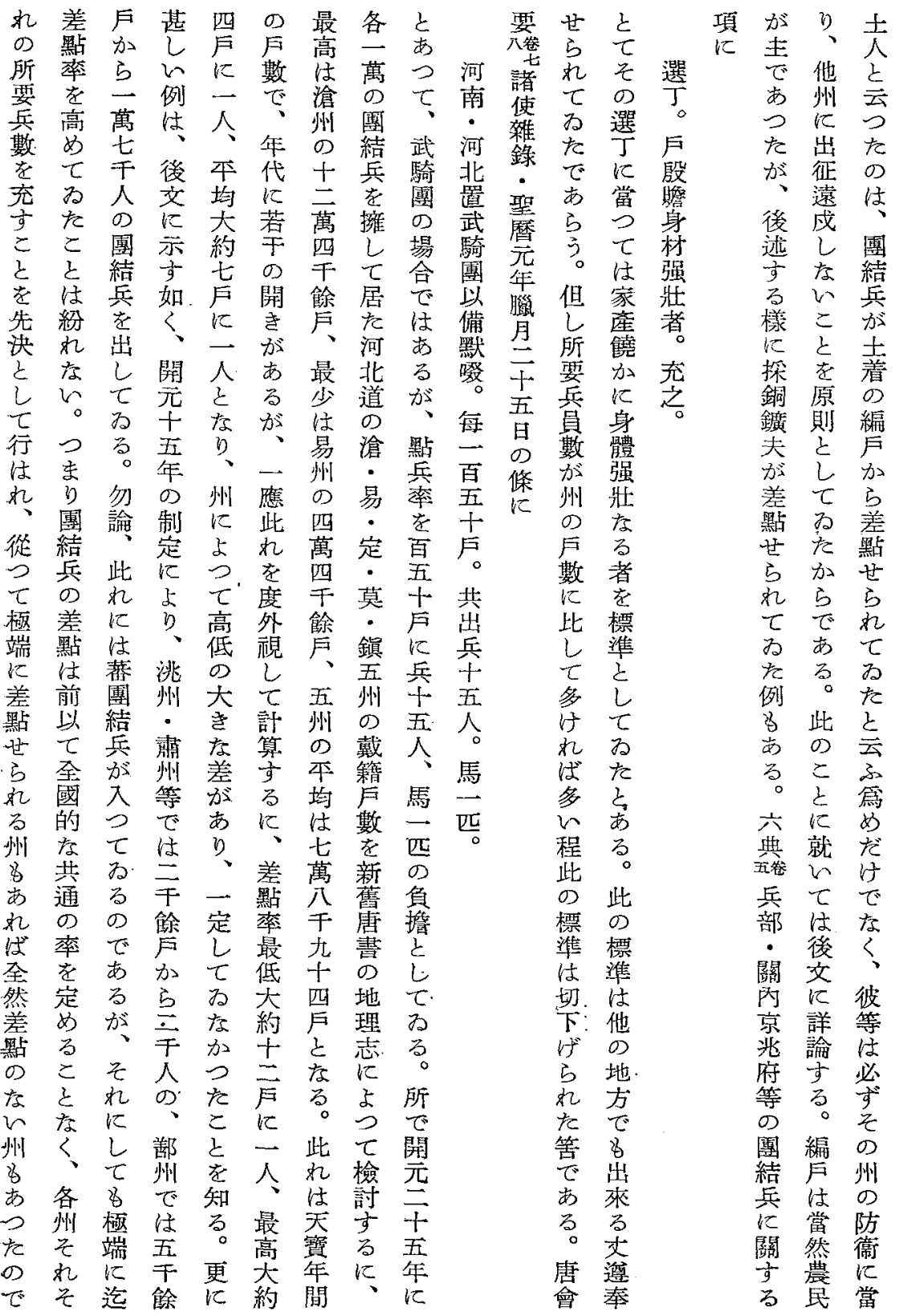


での彼大へて の檢大がに均户十ああ

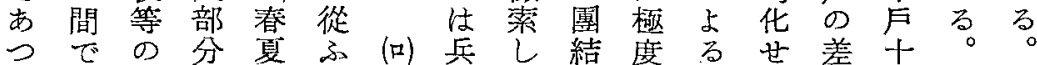

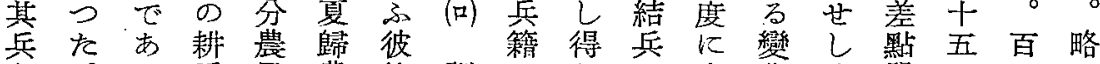
各。る 種 民農、等 訓が㾜沉高化め單了五方

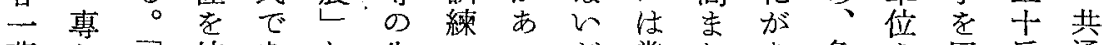

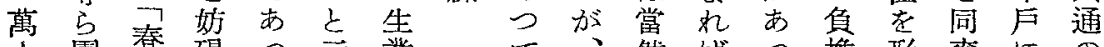
人團春碍つ云業て然ばつ擔形率に市

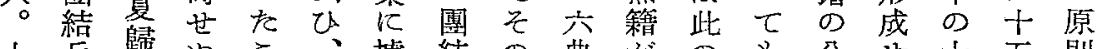

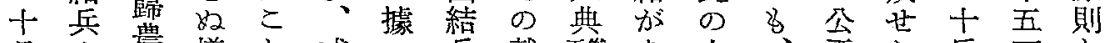

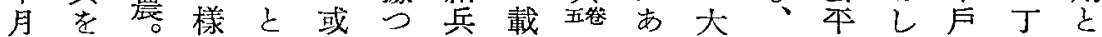

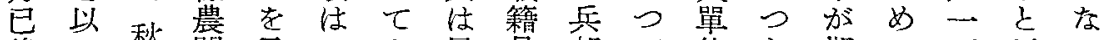

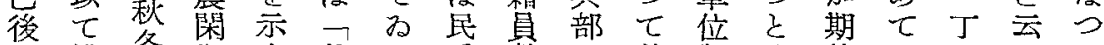

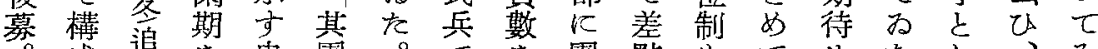

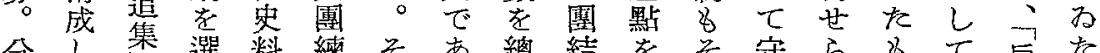

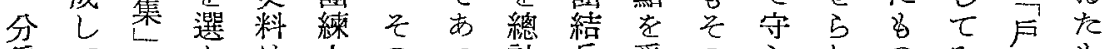

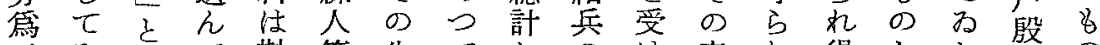

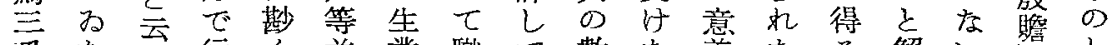

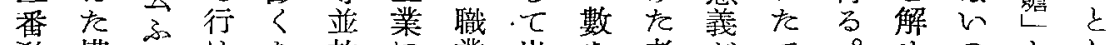

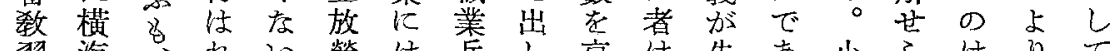
習海、的々營は兵し京は失あ、小らはりて - 實な。農色士た兆此は主單れ取注

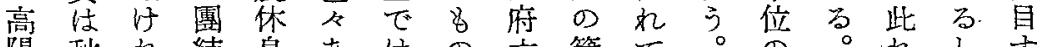

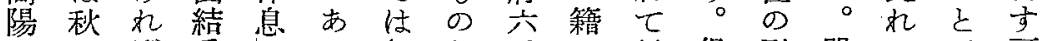
- の壮兵北つ無と千に行但形單が云可

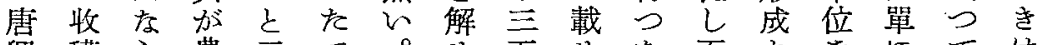

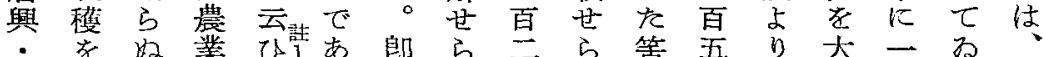

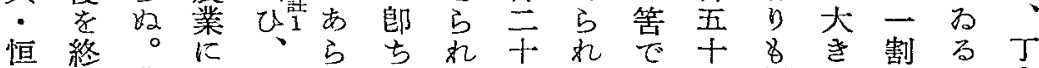

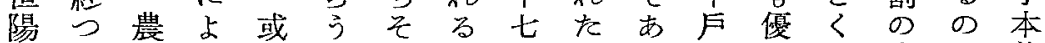

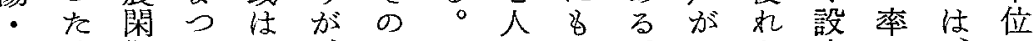

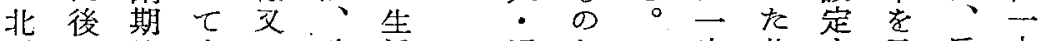

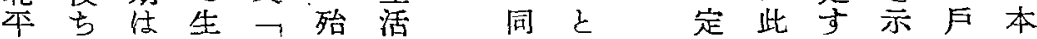
等で秋 活 所九 の 州思不の犳すををで の、の籍を゙資六は變大㕦䍃重な

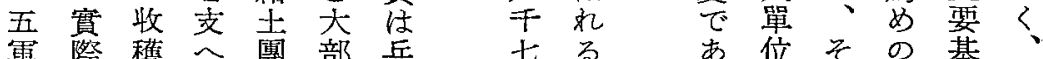

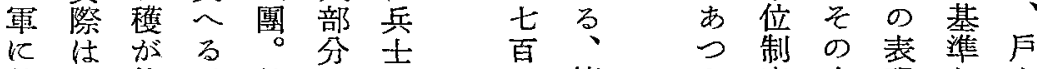

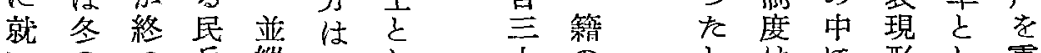

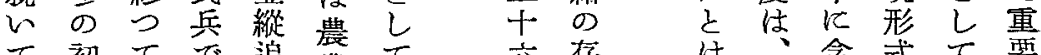
て初てで追業て 六存度含式て 要

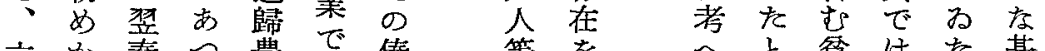
六か春つ農で俸等ををへと筫はをた 基

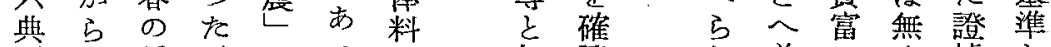

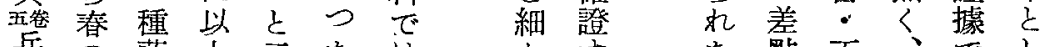

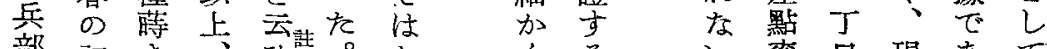

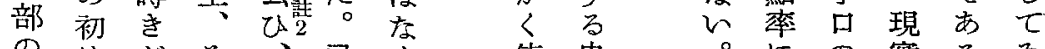

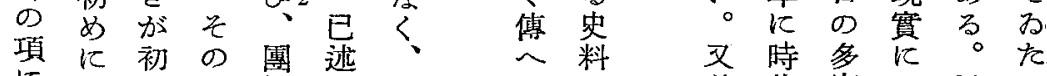

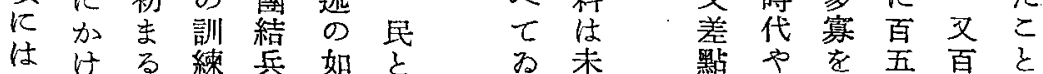

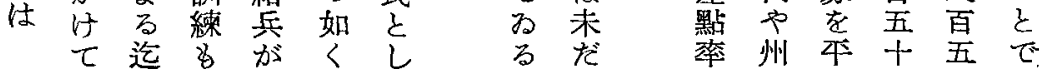




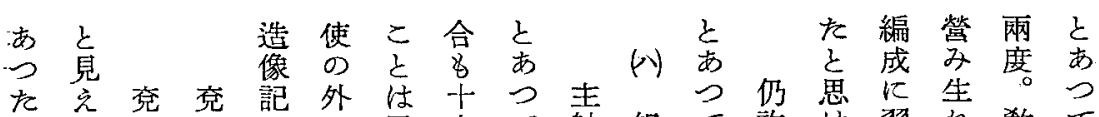

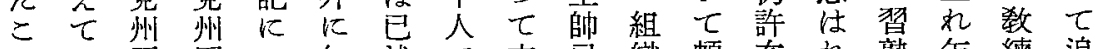

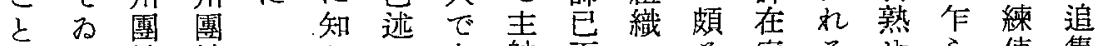
る 練練 ら市帥午当家るせ方使集 右、使使如る以統戰常。しに知は 記團都押るく。領六技習漢め兵部冬 事練虞牙軍で所の芝典訓旱噋て土伍の を使候: 職あで統。五鵕練矢結おたし初 一正忠る團率火兵を。兵くるとめ 見團銀武名結官十部重每にの彼あた

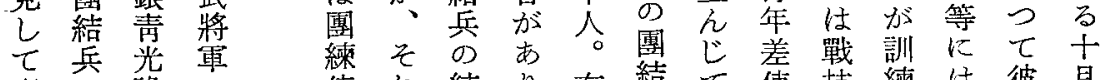
察の旋・使れ結り、有結七使技練は彼月

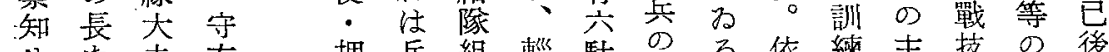

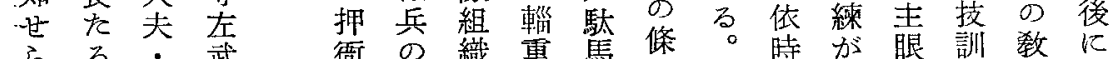

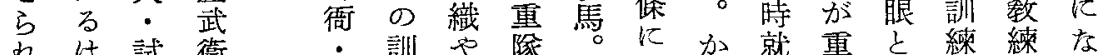
れは試 㒖

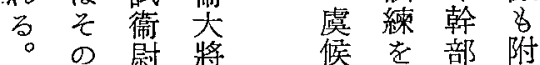

團名卿軍只職 將 設 練 上・・ 三 兵 $引$ 上 團 推、桂 桂 D $L$ 國 國 長 $\tau$ 高趙

薄 明 晃 俊

練 で

.使 あ

充 !

会押

等

䨘 衙

城 都

守 候

捉 が

㨐

守 赫

長 の

老幹

部

軍

ぞ 職

和で

でる就れ

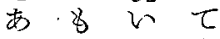

る。

金所乞

石兵傳

粹團はが

編 0 殆見

三登統 ん完

所筑索索。

收織く、火

代本詳部

岳筋 細 榢

觀上を編

碑 $儿$ 知 成

の 在 万人

聖 る 難 最

曆雷、低

元職。單

年で敉 位

臘は練で

月应使

武年尔

時教古兵

○練た場
う試要存のはつ

乙䛌元必只

た市て要一吕

訓つる年る

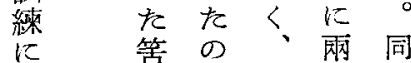

當管で只度卷

る あ古唐のに

のるら電部は

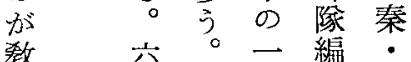

教六。編

練典吕翼成威

使 $の う と$ 等

で關ししは六

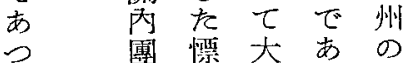

た結，㥍規つ高

わ兵索模を麗

け 手蕃と。

で條團集あ差

あ に結 國る等

る 兵戰 がの

の 法、蕃

差に獵團

點 役 農 結

は立或兵

時たは流

に 獵就

高る牧い

率可のて

でく生 ᄀ

あ部活 每

つ榢を年 
を等規戰て兵名軍め出押のはが使そ幕簐 以。兵時生 8 、銦 $\tau \supset$ 官組れ括・の不

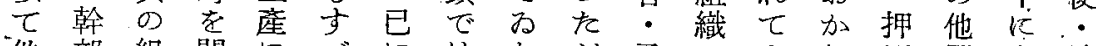

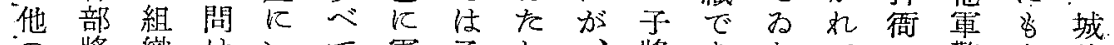

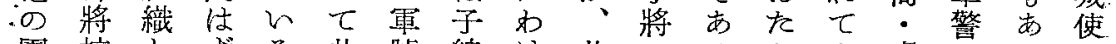

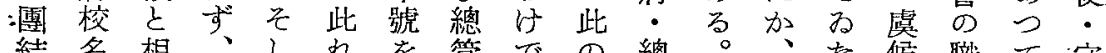
結名相、しれを管での總。市候職て守 營の似そえと有とあ吾管六此で.を最捉 ‘共た ので同しなる。軍に典れ古教掌高使

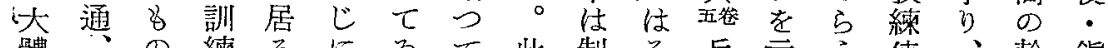

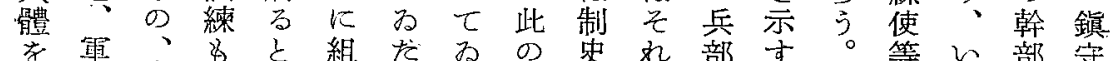
類號少組 推をく織云せ上違織軍杂記料開すば校と

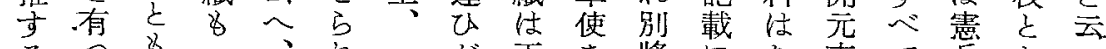

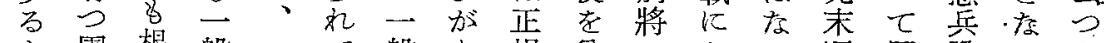

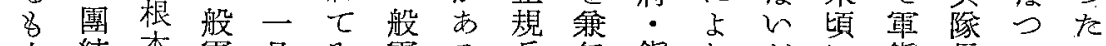

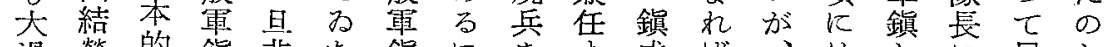

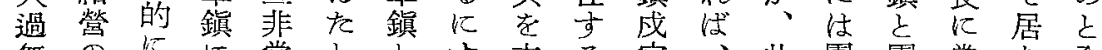

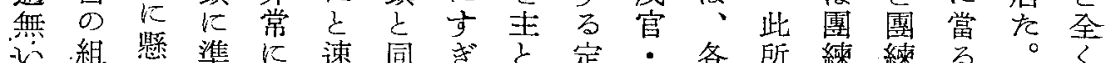

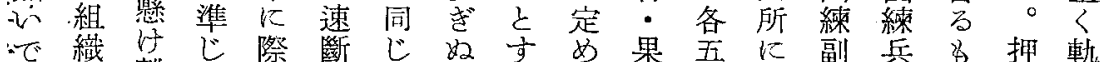

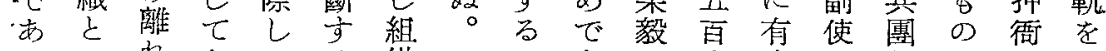

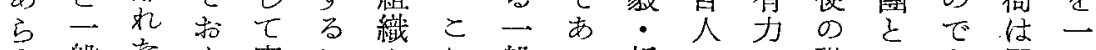

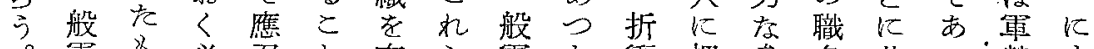

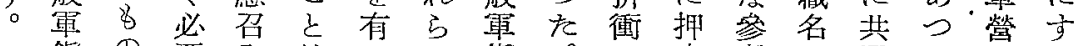

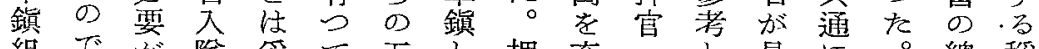

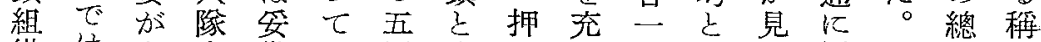

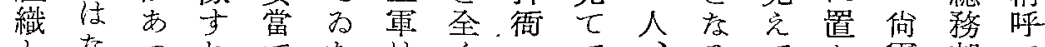

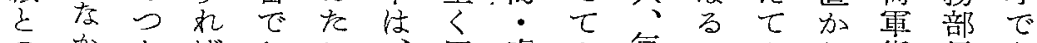

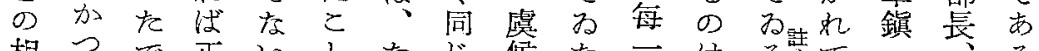

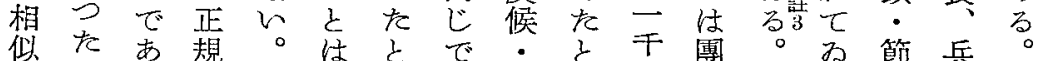

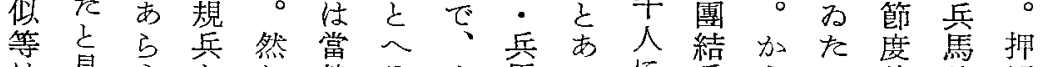

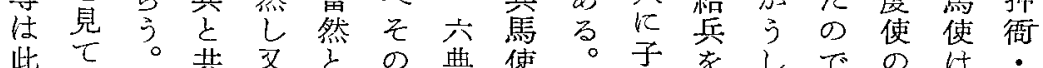

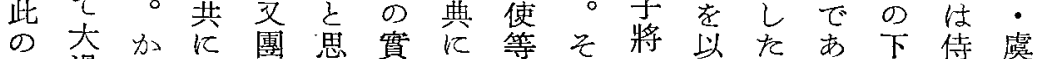

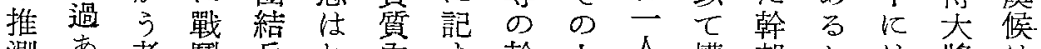

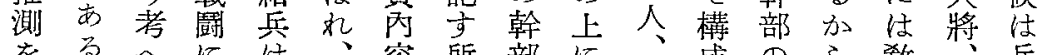

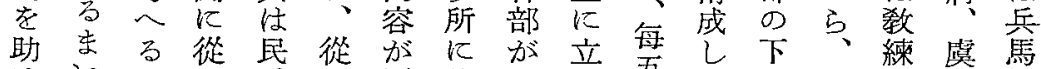

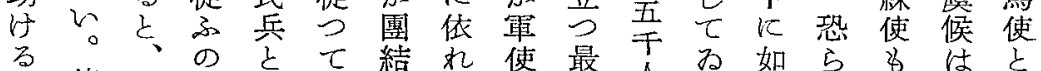

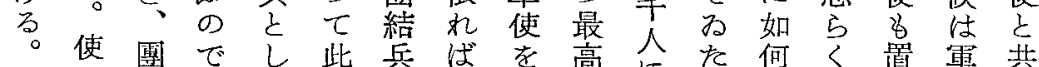

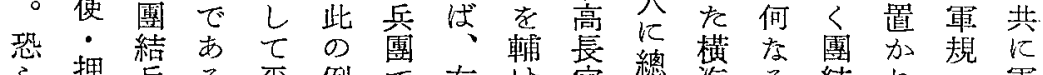
ら押兵る本例で右け官總海る結れり霜

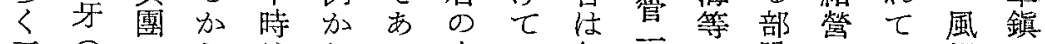

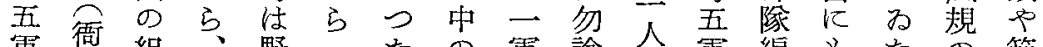

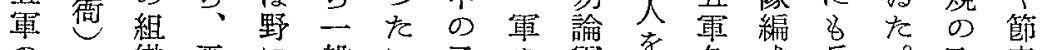
の・織本に般に子学置各成兵。取度

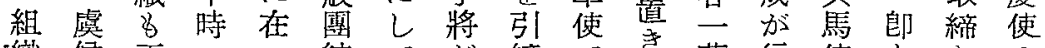
織 候 正・つ結てが締でさ、萬行使ち り 


\section{大唐府兵制時代の團結兵に就いて}

で如と治らや集團及の此官止ま結對

あくて通類はに結し葍の給まで兵すに

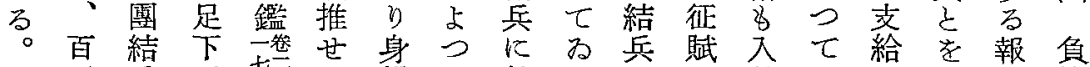

而五兵所唐

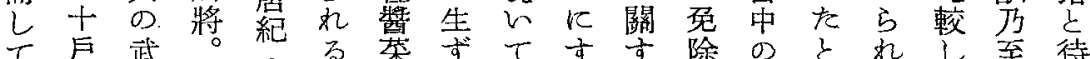

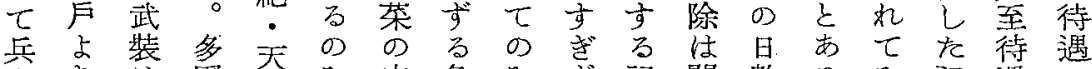

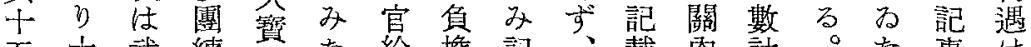

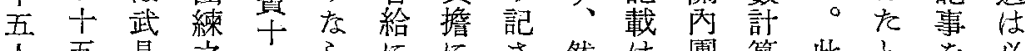

人五具之四らににさ然は團算此をを必團

を丁

出の武。+、卞七團め兵以とるげし兵

于 橉器 無六

百結共堅百典 $\tau$ 報る兵不限行內對之良義

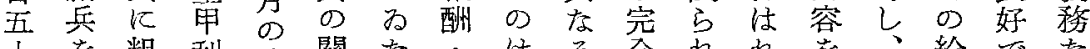

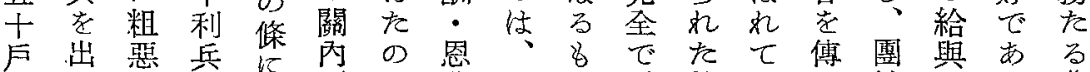

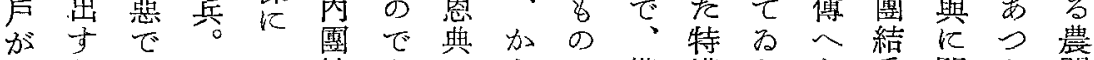

馬をあ結あそうの僅權をた兵關を䦥

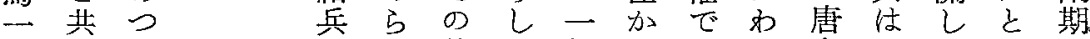

匹

学馬文

擔匹埌

灰出p

事岂は

かしり

め 官

推在給

せとで

壮あ店

当分

武办了

器

$\therefore$ ¿

武馬

具 巳

そへ暗

の是示

他民 ᄂ

の $\sigma \tau$

角负

擔擔る

勇

時口先

應て洒

召示

中たし

の の

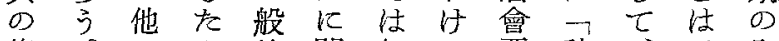

條口穴的. 關無で要秋、云入

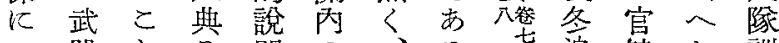

$\neg$ 器々 そ明 の、る。追健な訓

仍: はの記京天。記集は心。練

許武制 8 事兆下具

家等交の殆蒲般典结身蒙治常

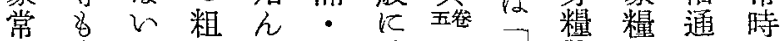

習官肪略

矢で特因ら華计の—衣五軍

店別る盛四ら關身とし唐と

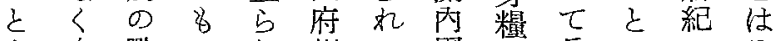

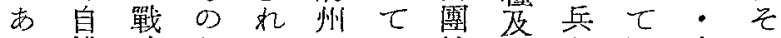

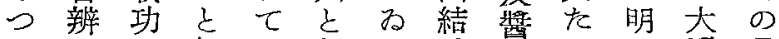

てであ解わ劍た兵暮る加歷最

弓あるせな南为の者に十大

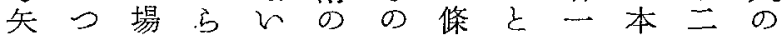

の在合れ。黎と西身人年负

自のはる征・見つるのの五据

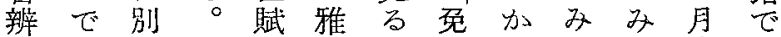

をあ

暗 らし時除五き征、食方永口

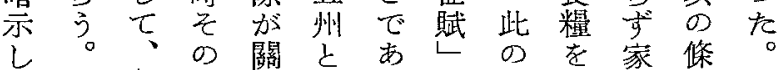

て府之他丙の方々一官族飞此

招兵のの四そ引市身給分官の

りの手非府れ。る

例當常州に公が食る手之擔

資加注否の言典、糧に當團に 
之鄉の障あ等結る防經結 れの民方つの兵、衞嚌兵應 飞防兵れた大此飞的を召 基衞々ば。ん敢所は染し職

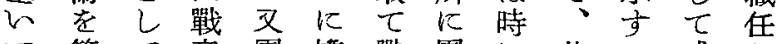
$\tau$ 第 $\tau$ 意團 嫌 戰團に此に我之 決一のを結少功結官所震事戰 め任此变兵所を兵健に令に副 ら務れふはで逐のに團精從力 机了何民的置劣結兵子 た の 險兵强こ加 5 兵?民 職、諸がと制とれ好の土兵團 任出條あし的をた戰お團で結 を征件つてにし第鬪加のあ兵 示遠をた鄉出な素力れ對つは

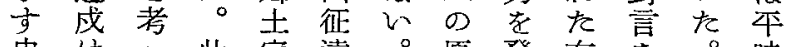
史は 人此家遠。原發有を。時 例出之所族戍寧因揮力以民は は來机のせるがしななて兵そ 藩るに名安し鄉あた二せ店の 鎮丈基亦全め土つ。因方る職 時避々團をらのた巧がれが業 代けて 結國机防。にある故に 飞て決兵家 $\tau$ 衙官郷つ有にい 入正定活 08 兵 $\pm た$ 樣 熾 つ規 女用大決關は愛。で業し $\tau$ 兵 5 上局 $L$ 係戰老又古兵ん 後を机の上ての功鼓團つ士で ち繰て問り力なを舞結をに生 、出わ題\&をい邀し兵。比計 郎したが優盡戰求そは然しを

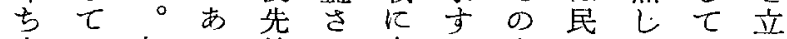

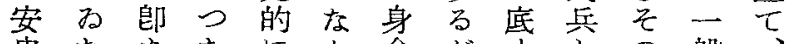
史たちたにか命が力之の般 のの團わ考つを、ををし待に農 亂で結けへた賭生發。て遇戰䦥 以あ兵で、。活揮々汇闑期 後るはあ從此るの世於力住 に。正るつ所老し基々家いに團

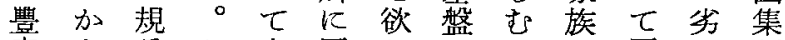

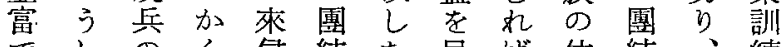
でしのく侵結店民ば佳結、練 た補ての兵かと大む兵時を 以團助團敵活

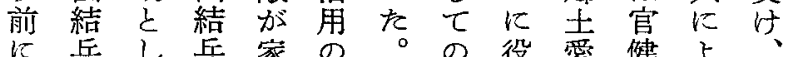
に兵し兵家の 出生立菜健よ綏 殆戰置職の芷業立强比て念 え㕑汃任安を遠にたくし官に ぞ精れは全限戍打の、遥健際 見神、彼を界はくで州か。兄 出や州等保㤎彼團あ鄉に團て

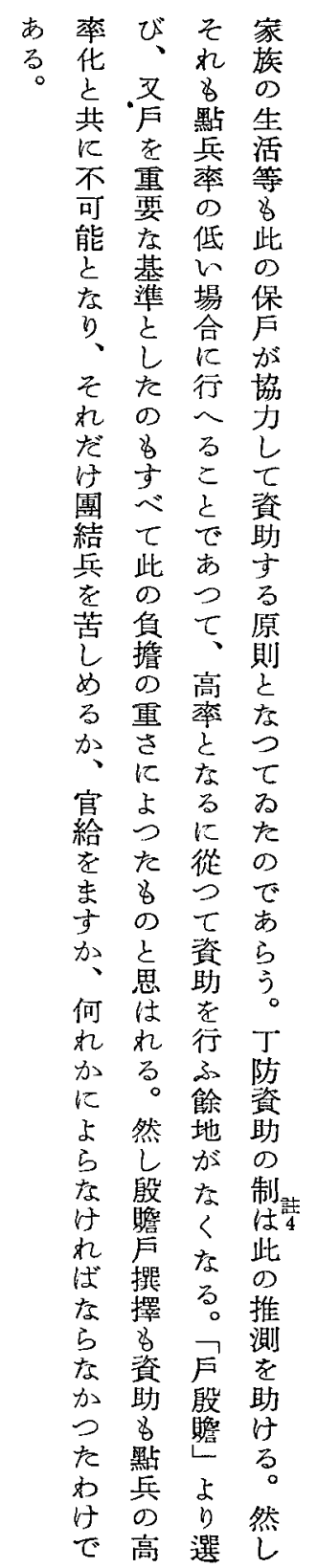


結 結と

營局 あ。却橱合何

を力場はと

を召年に 在 儀

せ

以集十入口資疗

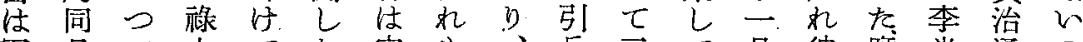

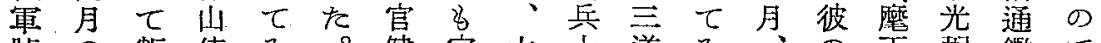

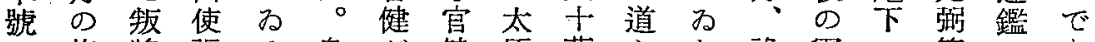

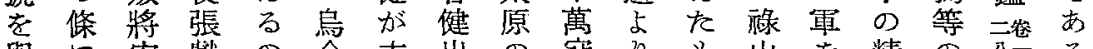

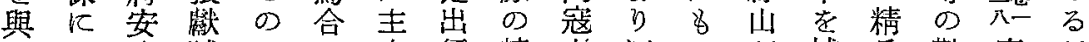

へᄀ丞誠での征精太河の が補兵勤唐が

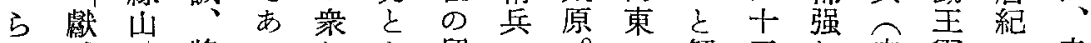

狄誠が將ると店留へ。の解五し官電・幸

た果唐上、云り守官李太せ萬た健茷至ひ

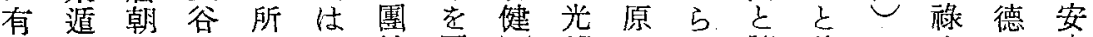

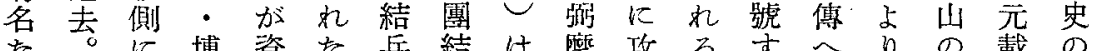

な。に博資た兵結は藦攻るすすへりの載の

精 其立陵 治 一 肪兵皆午め。当て二本五亂

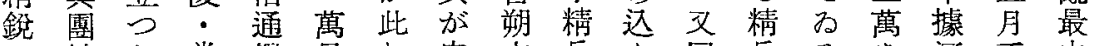

汇練た常鑑足机守方兵ん同兵る老河王中

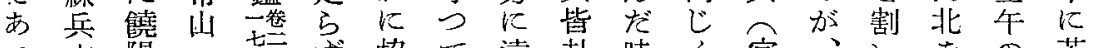

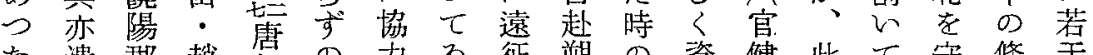

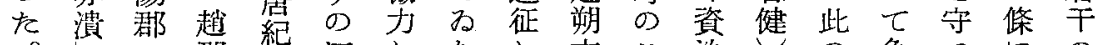

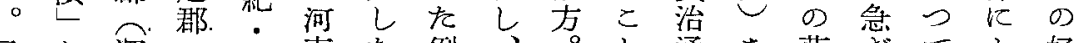

又と梁・文東た例范苍て上好

深あ州交琵のわで留餘を鑑悉陽河るれ 例

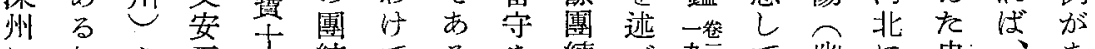

に如を五四結でるを練べ九地幽に史、市

はく吾郡 年兵あ。守鳥て 唐 南州歸思徒つ

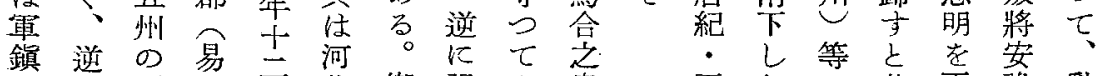

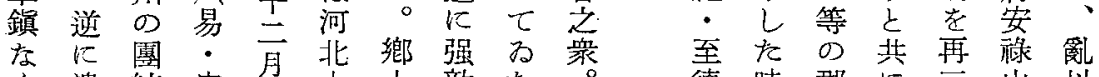

く潰結定

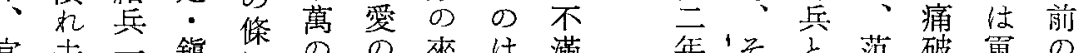

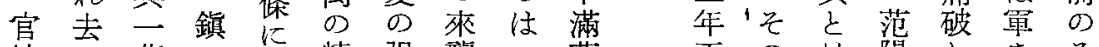

健つ萬

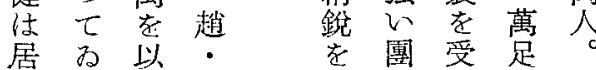

店るて莫逆結付 思

かの攻五 人兵七ず明

つで圍州掏はその 以

たあせせ優の團票

のるし国、秀防結太

で。め結名指衞兵原

あ易を。兵將揮にで指

る 所手李官全あ堂

加定少光力口可

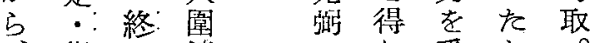

鎮 K 䬶

の水悉

五・拔陽

郡莫く沙

の諸 能

兵州洁

をの ず

下ばさ云云

に防福学

終衞ば

にに存此

此勇 られ

正の住陽しをと

月會、等菜れ

の府 後の形るを

條た文郡勢七立

にるに，兵惡河證

、幽諭萬化南委

河州證餘しにる

北の 劣を在入こ

の留る出のりと

叛等如動で洛が

将をく世淂出

史守團し䘵を來

思 $ら$ 結 山占る

明し兵てに領

がめの史從し

十 hこ思つた

萬がと明てが、

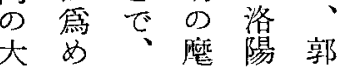

丸 戰 ぬ

軍に昨卡に子 
あ を

り並 り爷勅刺兵

元刺六河史

和史典北 0 ：統

郡自五管諸 統屬

懸 押 兵 州 領 關

志項 部 加。保

四簢 黎 練

內道 雅兵册

會 的馬完は

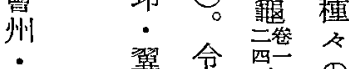

會翼 令 西

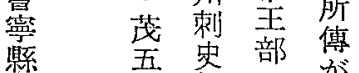

の 州押 落

條

に
征み召向

にた入を以例く結頑防て

怯 9 營有上\&此兵張衛深

惰でしし藩れ㤂り、圊州

であ、て 依鍢を攻、結を:

ある官わ 據時鼓弱翌兵守

る。兵た史代舞守云をり。

の出に II が征協ではは用の、り以 彼遠力、立少し 兵太得た 就統等 成し彼し加得厄゙原高兵 屬 の は、等 $心 ら$ る 特よ或に名良つ李逆當 色くは對、認將を 光に然

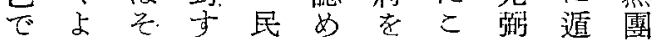
あくのる兵ら得とが走結 $つ の$ 出職た如存來し兵 た事征任るる仔示援た兵

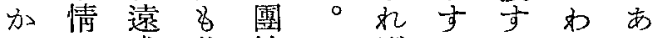
らが戌此結任二るけつ でなのの兵脆適迄でた

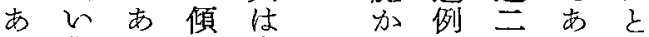
る限之向 鄉它卋る 見 りのに土市元。店 彼防沿愛るる日墚け 等龦つに长間州れ のにて基得但をはぼ 使虽與认基它支翣な

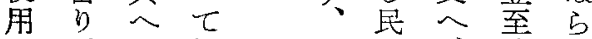
を、它活、强兵、德 官如動 烈々 内 元。 七 0 平、防李呼正州

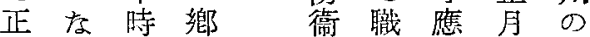
岳いは土意業しに精 を所農 の 識兵て 至銳 派で闌利䓃り團 遣は期害 燃た庆再結 し猲にをるるだ゙兵 て打訓國乍官る史一 わで練家家健史思萬 た州を全多に思明を 。鄉 受局 忽比明 0 選

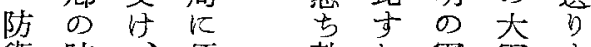
衞防、雾敵丸軍軍与 戰衞有先勢ばをにぐ に保事しに戰却圍つ

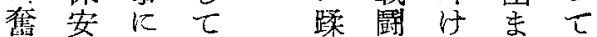

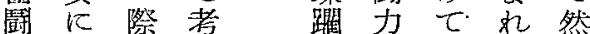
し任し せ劣る。た

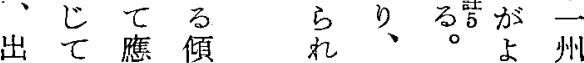




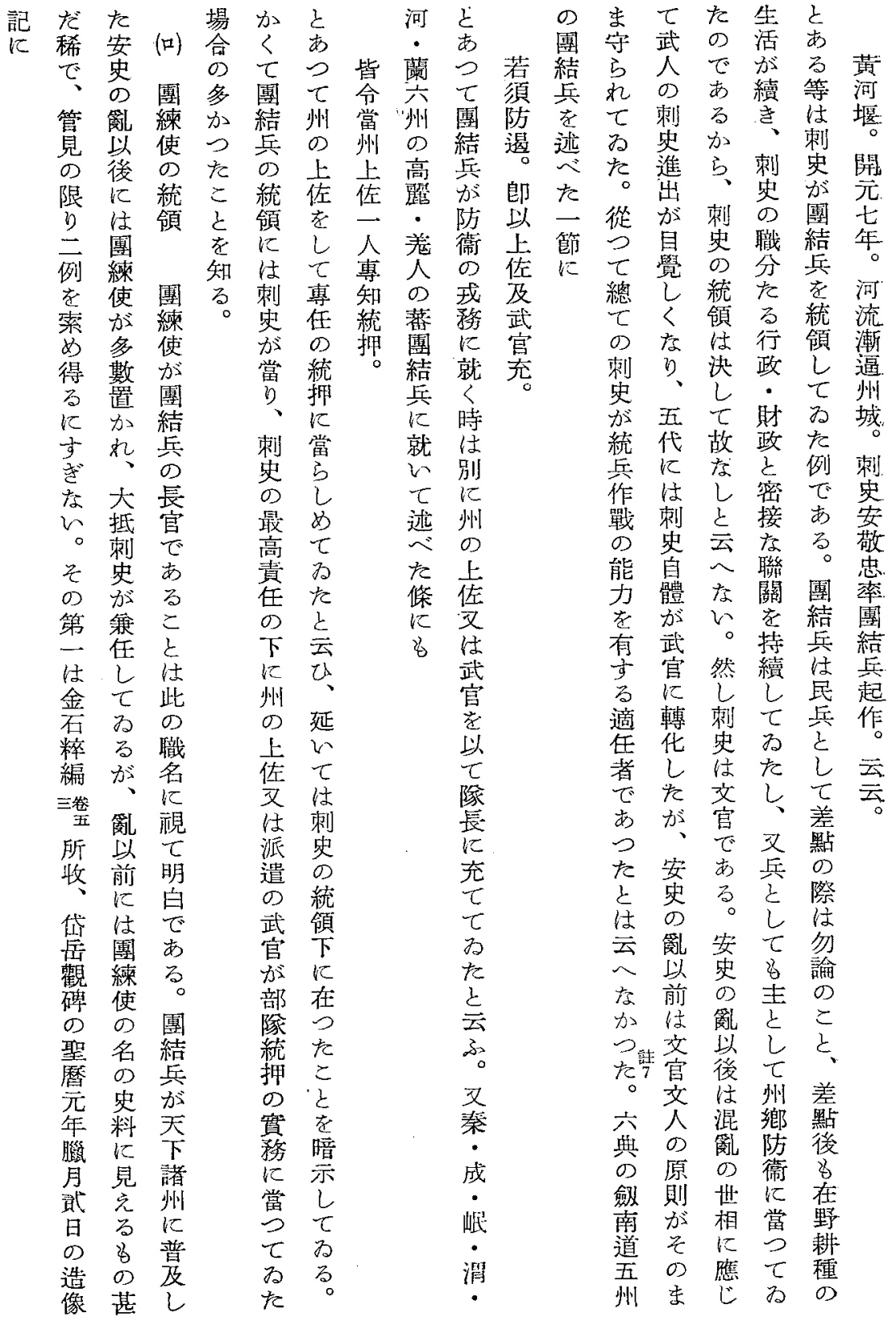


西

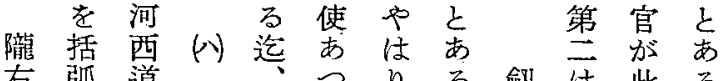

右。弧道

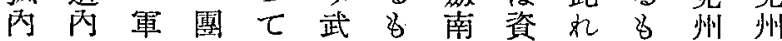

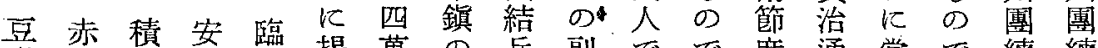
盧水石仁洮揭萬の兵副でで度通當で、練練

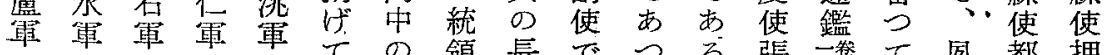

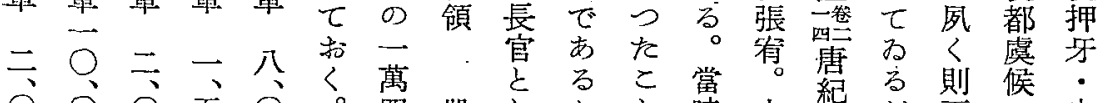

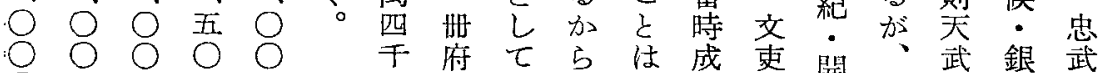

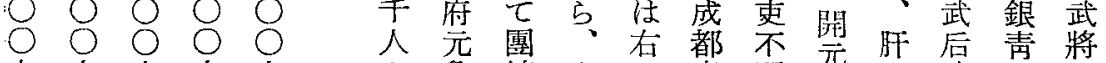
人久人久人を龜練やの府習元心時光軍

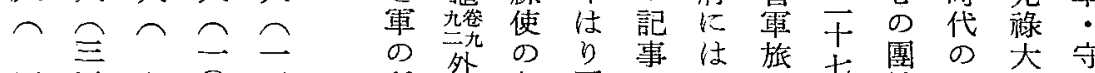
四恶卡

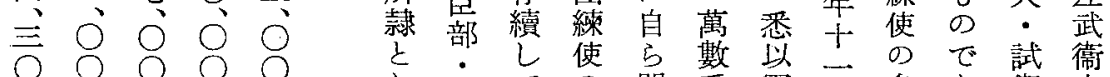

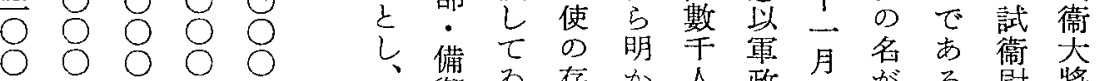

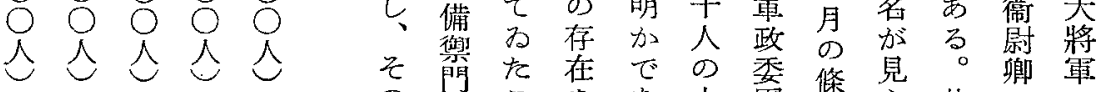

暮白河

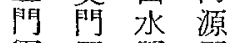
軍電箃霜

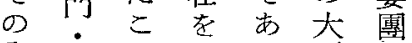

內開を示方團練

摆筧要。結副

條見。卿薄

二一宍

$\begin{array}{llll}0 & 8 & \text { 五 } & 8 \\ 8 & 8 & 0 & 8 \\ 0 & 0 & 0 & 0\end{array}$

$\begin{array}{lllllll}0 & 0 & 0 & 0\end{array}$

人众人

五五四二

三空 0 四

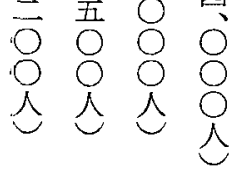

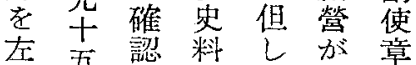

灾所 攴

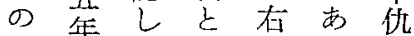

如年得見住口艓

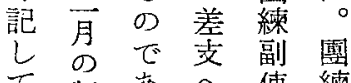

て制市父便練

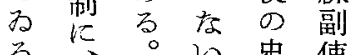

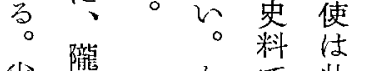

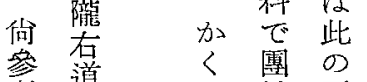

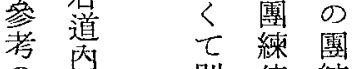

○圈 則使結

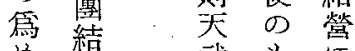

め管武名 6

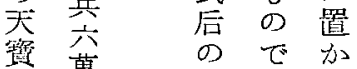

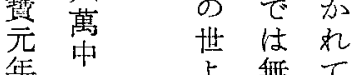

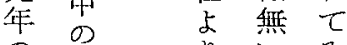

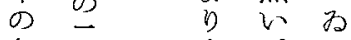

备苩蓄。长

苩萗然名

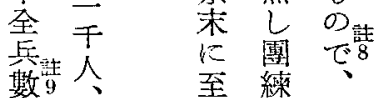

の 現國 國

でれ高趙

展俊

使 わ

の る

存 0

在 保

知 䌮

当使

下下

止

末 幹

勺部

そ職

r

內 る

容 牙

詳

詳 都

細 莫

制候

ら で

な共

數9 至練策战 
隴道と泷るる軍す募五は は

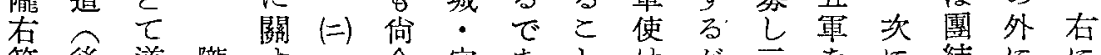
節 後 道隴 す 今守

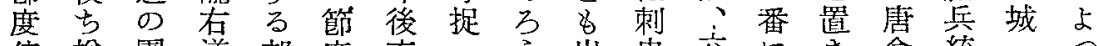
使增團道部度充: 引出史六飞き會統・ - L結共分使分鉏。來萧典分. 要領守

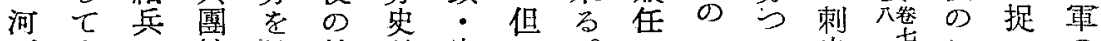

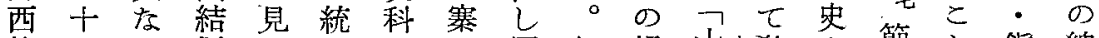

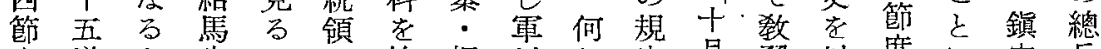
度道\&步に檢柵以れ定茼習以度に守兵

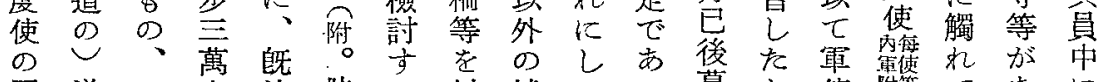

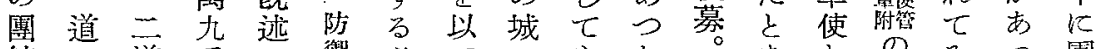

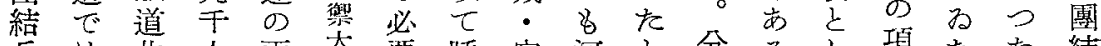

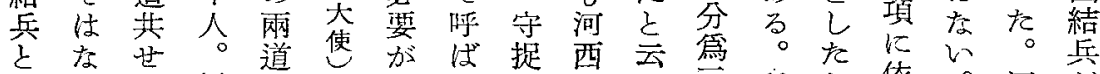

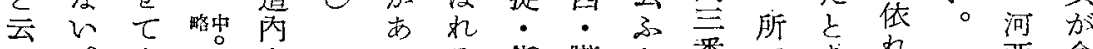

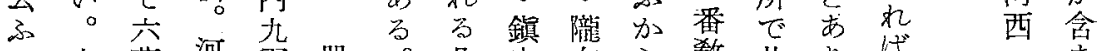
こ十萬河軍册。凡等在引教此り估、生

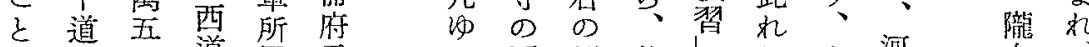

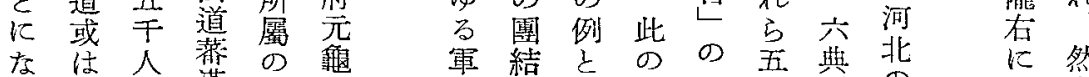

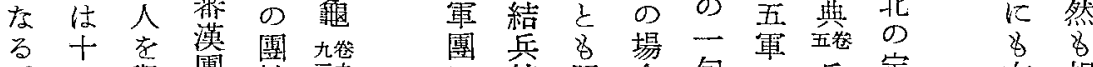

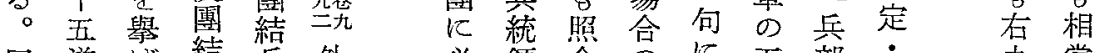
同道げ結兵处必領合の江五部恒古當 し $匚$ 兵合臣ずのし團徵萬に恒軍の

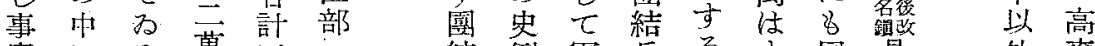
實にる萬至。結例雷兵る专同易外率

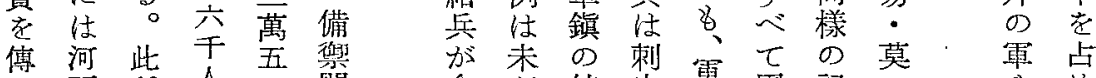

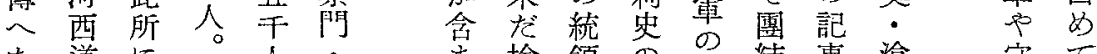
艺道治人。

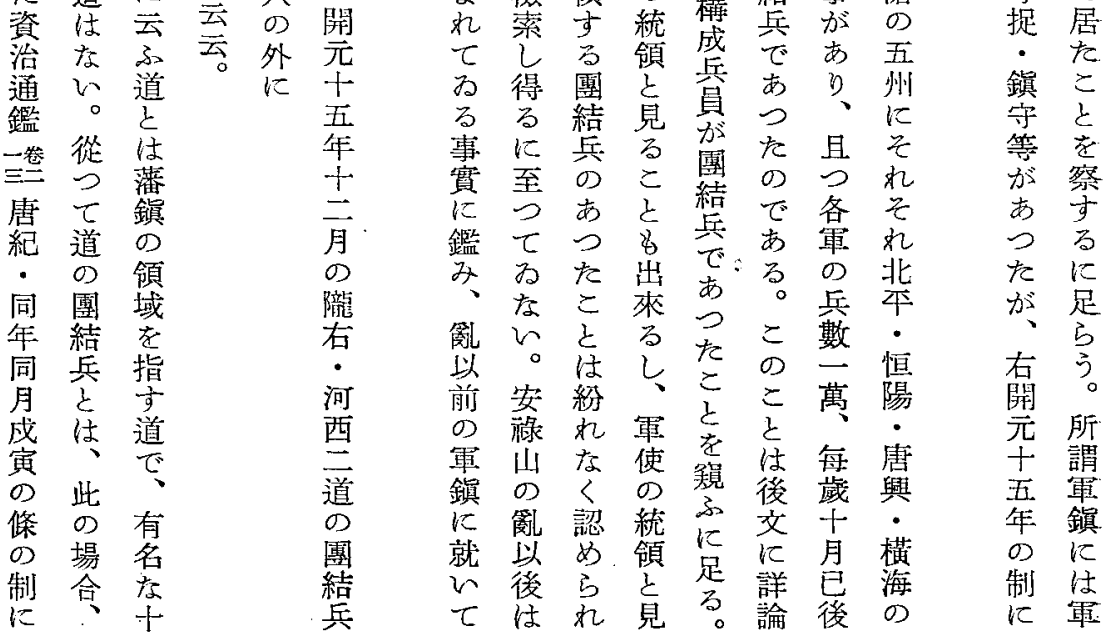




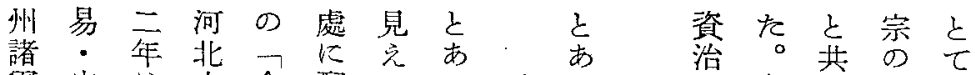

電定は方令配るつ以り以通道に束队令

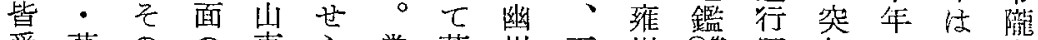
受莫の の 東ら當荒州夏州㔍軍如より 右

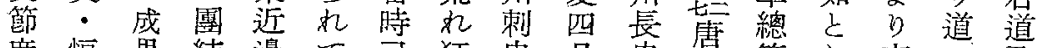

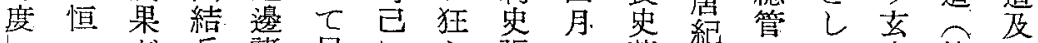

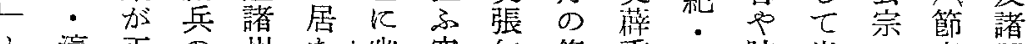
之瀛 正 0 州

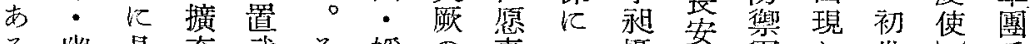

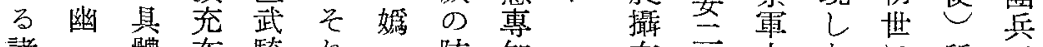
諸・體布騎机防知, 在绎大必所至

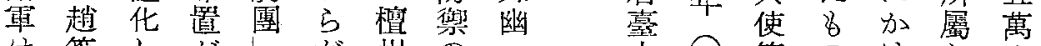

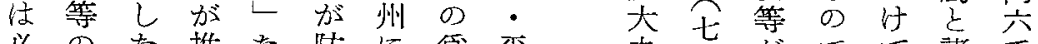
必のた推な防に編本吅

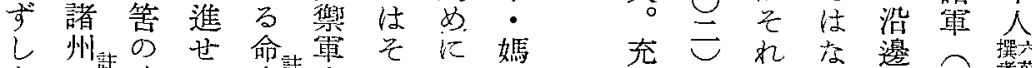

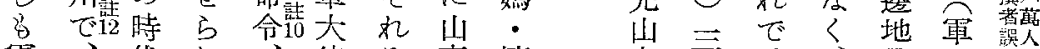

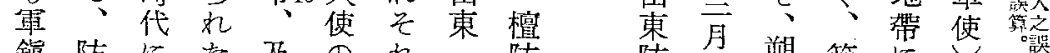
鎭防にた及的防

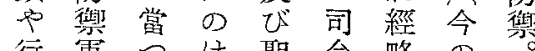
行電つは聖令略の票 軍大七防曆下電河仍 使 㝦元に. 北與 征のた電年和清季

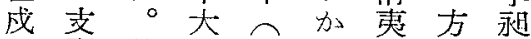
の配 然使六れ電面相

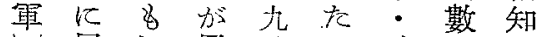
屬河置八こ武州。 の乙北文しを威の以 正た諸机の采軍諸拒 規地州た口云等軍突 兵で ああ中安南迄恒合 みるで光北多久司 で。最年置㐫的令 疗從名武る䨌官

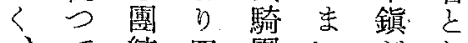

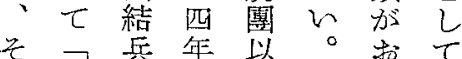
の滄の乃借佮咖防 團: 充至突萬れ倒 結瀛備六厥啙、霜 兵・ $L$ 年 L- 通又大 を幽て 前な゙ 天使 含・为る元時を 九易老乙命年的构 で・所々命11 ない わ恒结で等六电た た、、、を軍こ

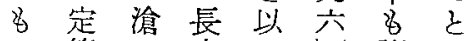
○等・安てし諸方

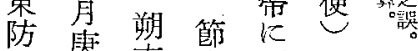
隼蔩方度列所河 軍富節使置屬西 大晔㦄以好道 使货使前ら西 滄前已热圊諸 。者 $飞$ 名兵團

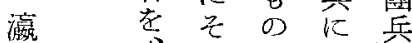
- 险ので分四

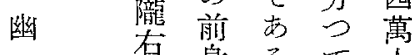
易節身方兄合 恒使罍然。

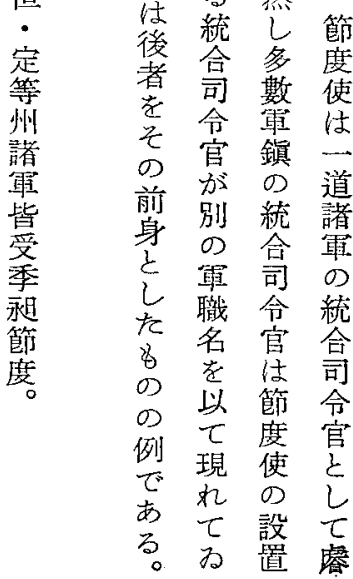


五め洲る る

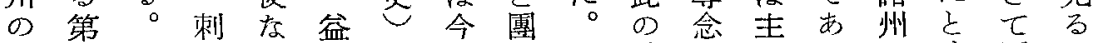

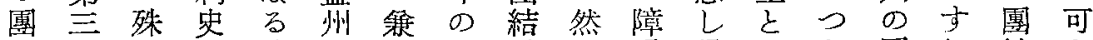
結 $の に \xi$ 武 $の$ 團所兵し 碍得した團れ結 熎根國武職—練出を此をなと結ば兵て に豩 結 職を萬使來 統の 除か 刺云兵、の あ

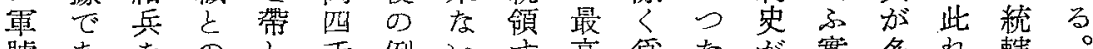

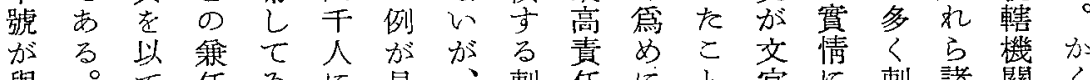

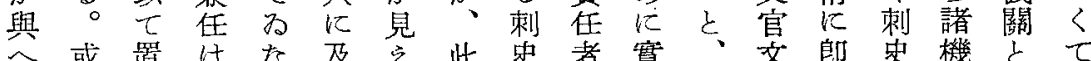

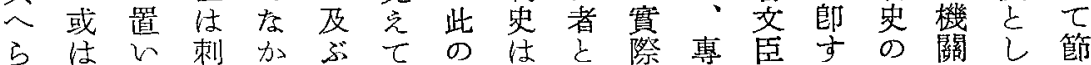

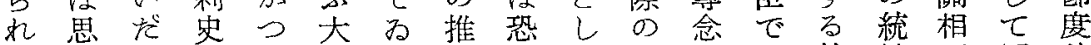

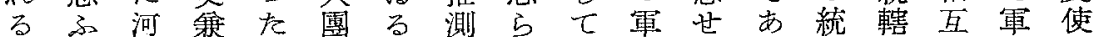

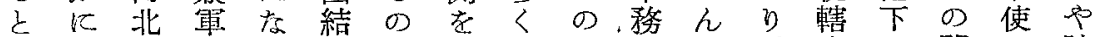
共、の使 5 營は强㕑長はと、方に聯・防

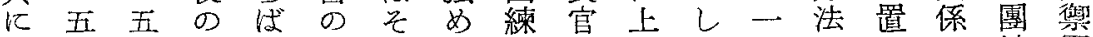

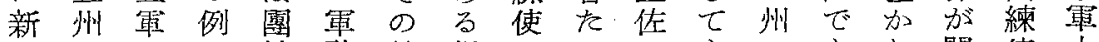
にの の が練 務第根ををる

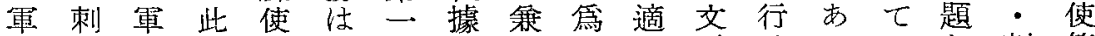
使史使のを武では㸚め任臣政つるると刺等

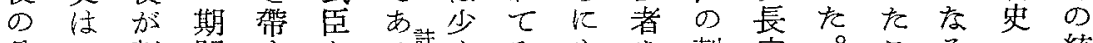

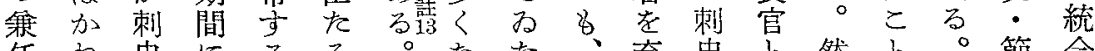

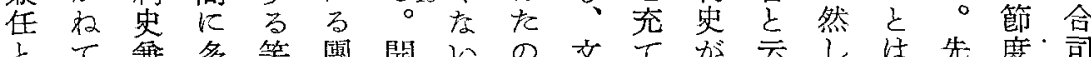
して 䈴 多䉥橉開W

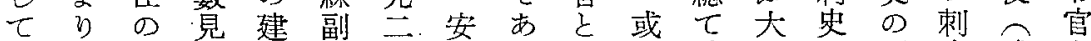
從團定之前使十史 5 武は適任 0 明史或 8 來練め、に章七の方職武任を團證と泪

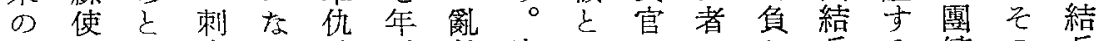
統を索史つ箫、勃安云をでふ兵る練の兵

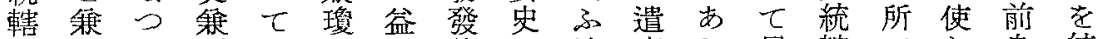

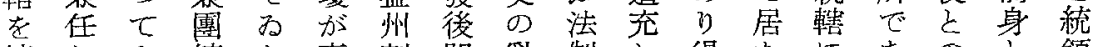

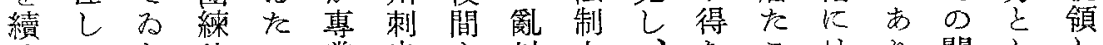

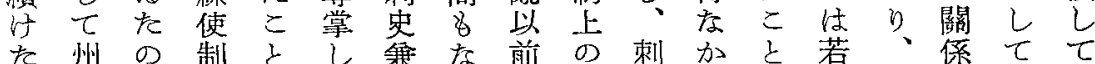

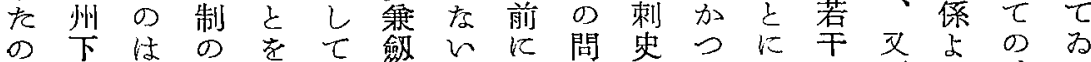

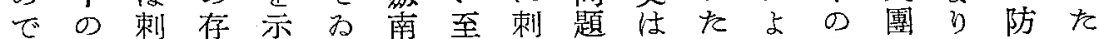
あ團史在した節德史が只こるる支結考嶶こ

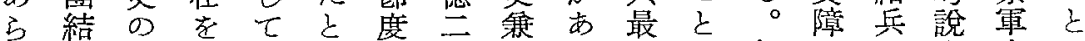
兵國推 る坛云使年國つ高等㓷ががす大が 。を練定る14ひ 張二.練た の の ち存州る。使認

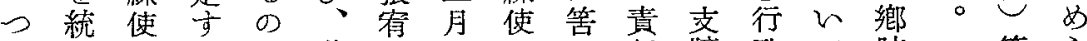

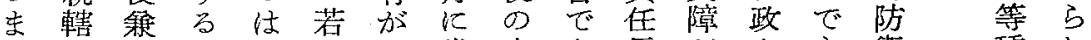

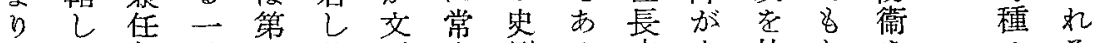
州七 制助三晙臣山例る官あ放存ををる

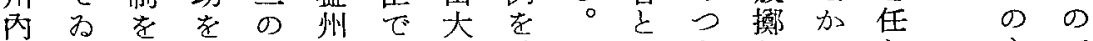

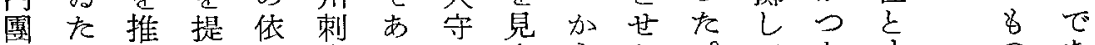

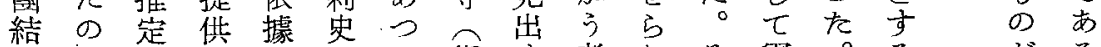

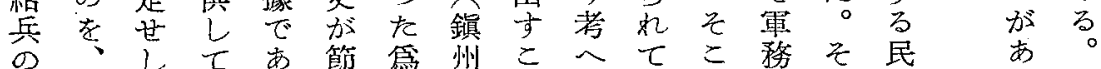


屬をり昧の兵けるるるるす第があ統

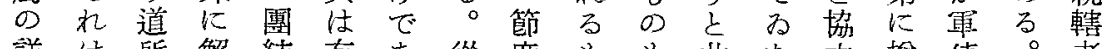
詳は所解結有あ從度子共を方增使。者

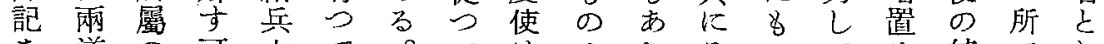

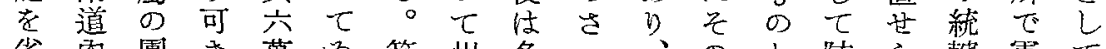
省丙團き萬わ節州多へ、のと防ら辖軍七

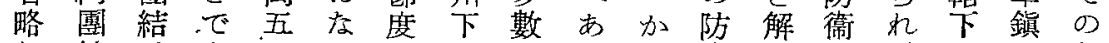

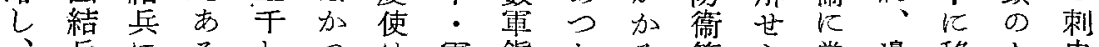

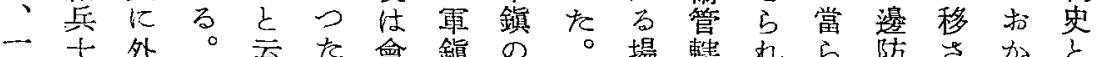

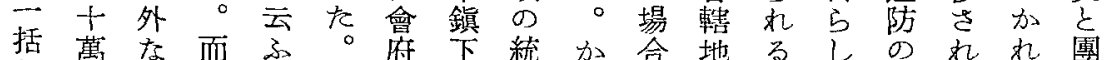

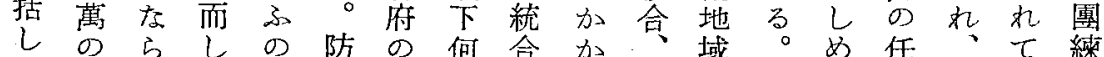

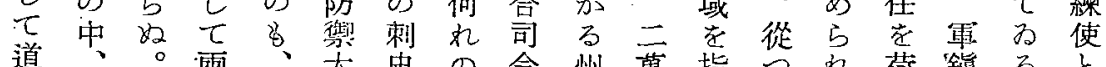

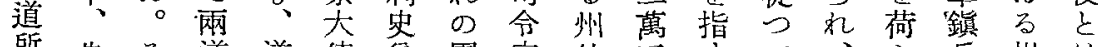

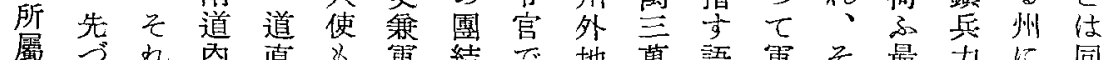

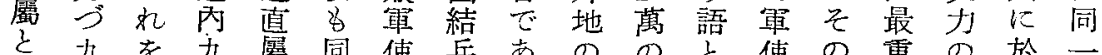

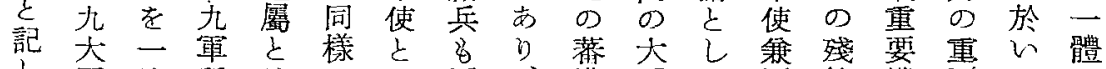
し軍は所はでし團、漠軍て團食機要てで 炎所道屬解あて練併嘈に多練の關なは、

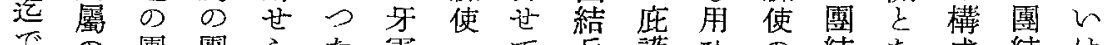

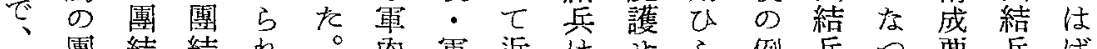
つ團結結れ穴近はせ例兵つ要兵ば

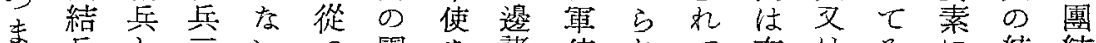
り兵・言、草團を諸使れて有はわに統結

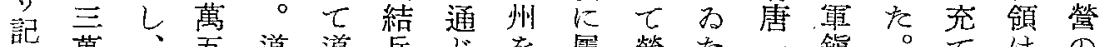

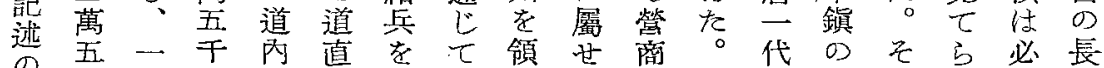

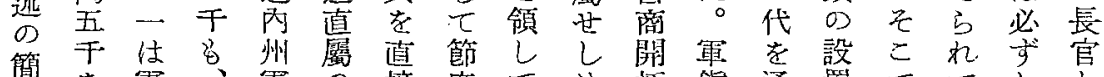
略を軍、電の接度て め拓鎮通置でてしを

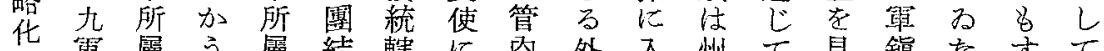

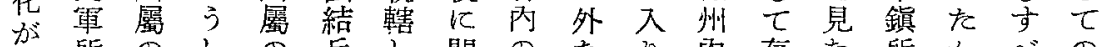

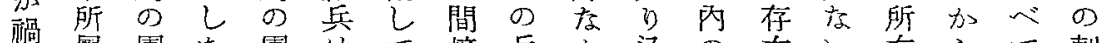

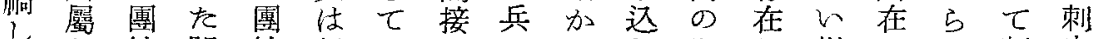

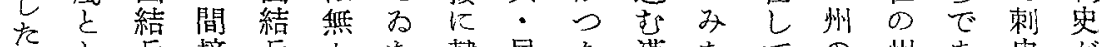

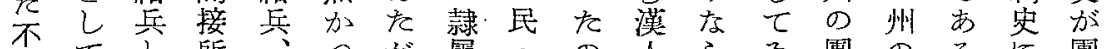

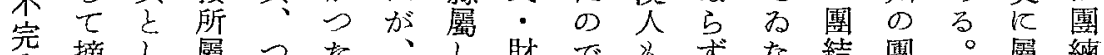

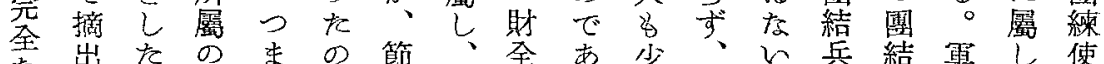

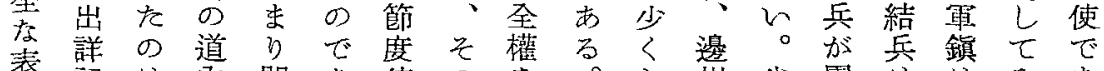
現記は丙間㐫使のを。な州份國はほな にし 何團接ると最總く外電練軍高なつ

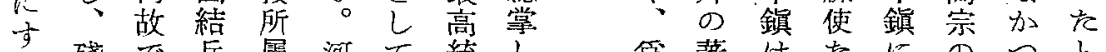

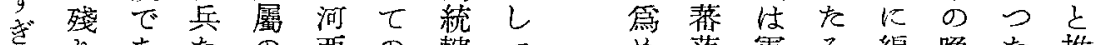
なりあたの西の轄て め落軍る編晩た推

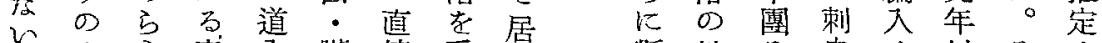

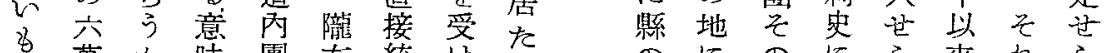

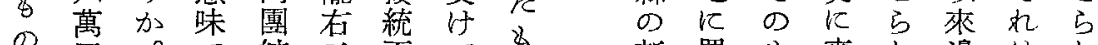

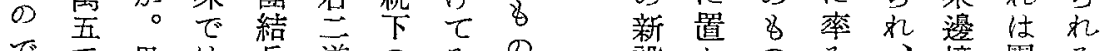
で千思は兵道のわの設かのる、境團る

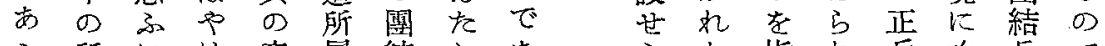
ら所には意屬結わあるた指れ兵次兵で 
大唐府兵制時代の国結兵に就いて

供主募

てを健つ略吉北澳傍

子な兒て。伐防に

た ᄂ 朔金制兵就

兵、專方山心力

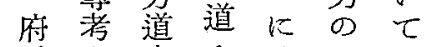

健岳竞方面朔藩重鬼

兒に要面塑著重蒐

中つる城道伐要秉

央七唐.傍行 の素料

正代怔電陣点は

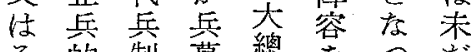

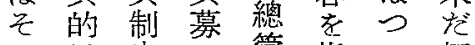

の地史管指 $\tau$ 極

許位上健張令 る

可を索兒侸し、夲

を占重曋等えこ少

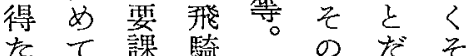

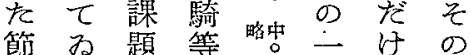

度たでと獎節は詳

使名、共墏に總細

- ○に漢於れを

電での萑兵いな究

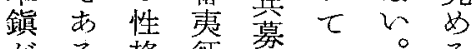

がる格征募し。る

自。は傠健唐に

兵今需兒健足

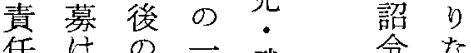

㶵は领な

者中究構留集

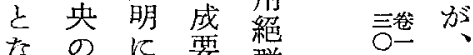

な割俟要群菜軍

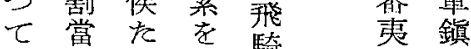

徵に放な騎方

募よばし城景唐

絀つな城鼠の

差て らる等四邊

亡州煌等防

でが方五吾を

算学摬

兵稚要学騎四罍

でをるし 日る

あつに云云

$つ て$ 電わ云。至

た徽鎮る 命呈

8 募兵。呂

の 提 の 兵

璄 時

の 8 ○呼

檢 芝外走 團

討 引 K が 結

の乙、西兵

結 た さ り

果稱引、は

浮呼しそ團

分の老れ練

び 檢 意等 兵

上討昧は。

(1) つはと先團城で代

$\tau$ 橉全に兵傍南の

城來結然團公傍吕團

兵閶結團郡結

城 系係兵伍郡兵

傍制のの・兵保

度店稱土州

郡を菠疄刺

兵究用上兵

之明 語 乙 等

にLをて

就 $\tau$ 以 紹 團

後て介を

七 5 示し含

簡 初さ施む

單めれが豆

に $\tau$ た聯

述 可團か の

べ能 結 う稱

$\tau \varepsilon$ 兵 $L$ 烀

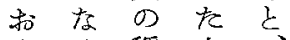

く学㛵老

よの の 國

○存 團 兵

て 否集 •

制に 兵土

度就た電

孛方。

專七意志

考当味 䤾

し $\rightarrow$ 兵

在考用等

本与語の

章るに土

の必盛を

附要 含

說茷込む

とあん一

しるだ聯

史

策

圄

練

使

又

は

軍

使

等

k

統

轄

世

b

z

$\not$

b

齐

ᄂ

節

度

使

k

間

接

的

最

此然呼稱 
結 と が見兒と

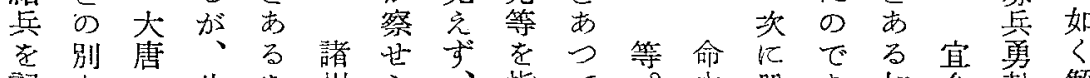

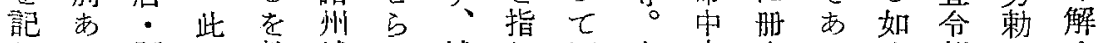
しる開熟城れ城し 河去官府るく朝飞坆

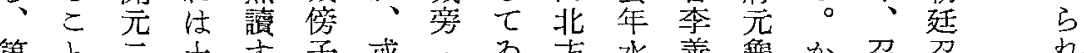

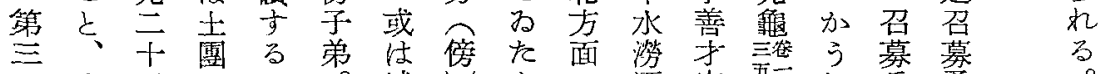

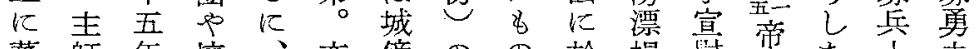

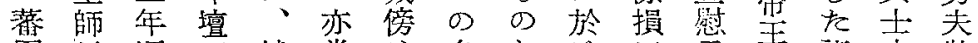

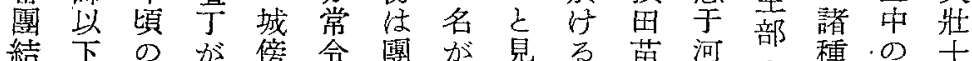

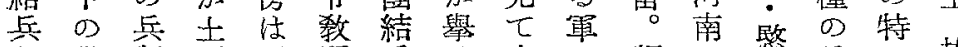

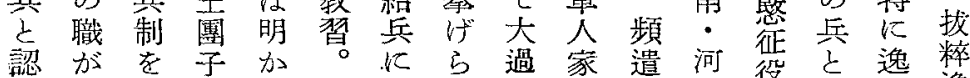

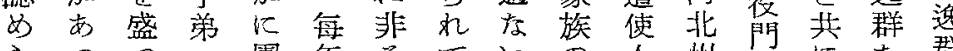

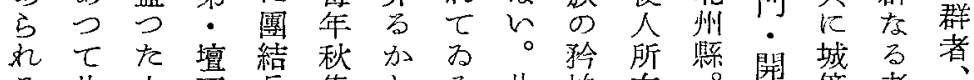
る此六丁兵集上る些恤在制元傍者程

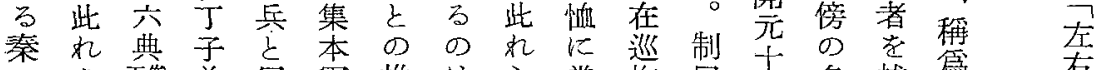

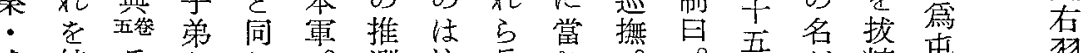

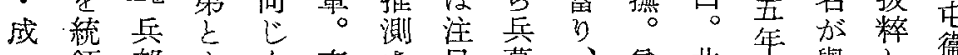
- 領部 b<春点目募、策北

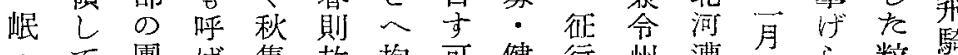
- て 團ば集放抱可健行州遭のら粒騄 渭わ結妃春散加き兒人縣水條杂選 • た 兵 $\tau$ 散 河こに为方

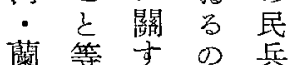
兵を当学 州述記同あ の ベ載—つ 高、を轍を 麗 次通でこ $\therefore$. 觀 $^{2}$ 羌關 宁城 が 兵內 尚傍 知 क $2 k z$ 二京、同れ 占兆先義当。 記同團 稱 ᄂ。伍呼典 、華にでに そ・越あは の蒲騎吕城 次四團。傍 下府 6 子 此州步弟 諸團團市 $\vec{己}$ 等

机あと城加城 るる共落矜要

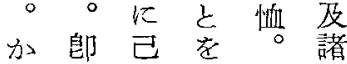

$<5 k$ 第萫

考城河 -

二傍北保

$\tau$ がの扱

六團邊

典結防

五兵浱

兵部重方。

の殊當

項李な時

に閣し衣

係征

を居行

有有人

團之

七 結 は

わ兵兵

た募

乙名寉

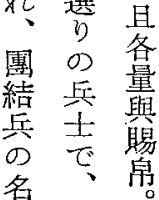

代さ行

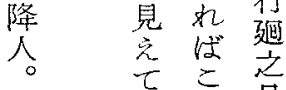

先方是。

鿖学武簡

㯰

及

州

䋣

被

差

征

行

人

家

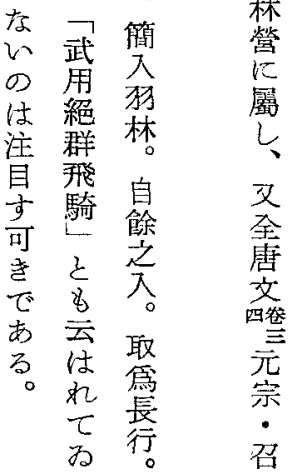




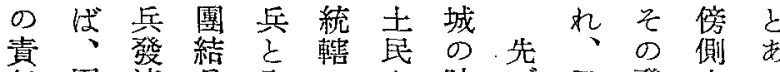

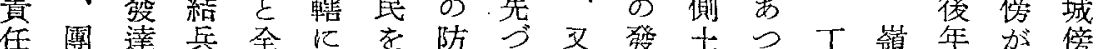

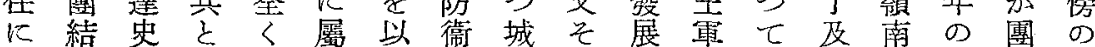
於兵のは同乙て傍のと藤傍西記結記 々度見全びた編在の發共意州側道事兵事 て中地々民筈成つ子展飞昧傍土笁での 編央汃の兵灾した弟後廣を側露度は部載 成の 5 同で、、篇を各地簡の。使あ類 证 統命詳義市六秋め只依域略土以蔡るに: 轄令考語つ带集でて然の化軍攻恋が入最 しにすでたに春な編と子しを登第、る後 七ょる區こ散け成し弟た率州政資民飞

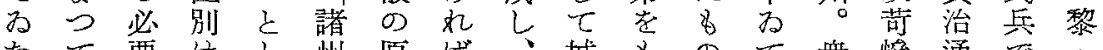

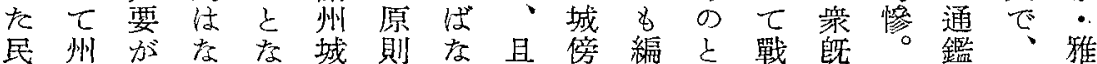

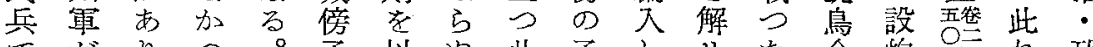

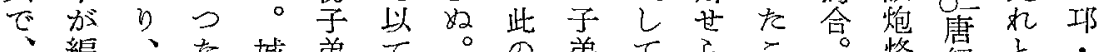

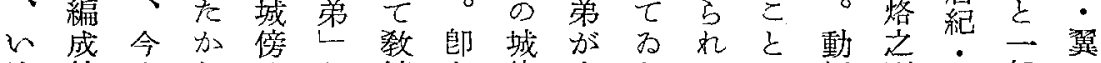

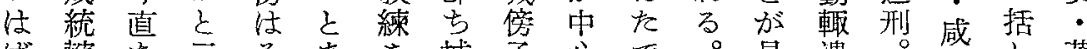

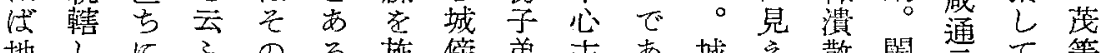

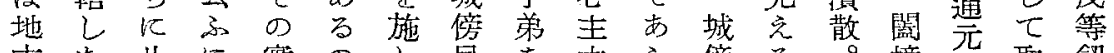

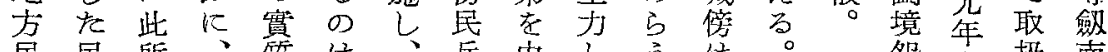
民民所、䝷は、兵中主は怨九报南

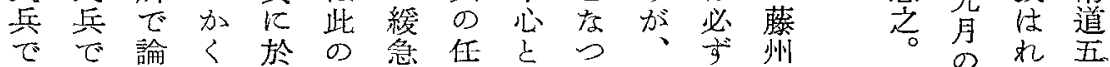

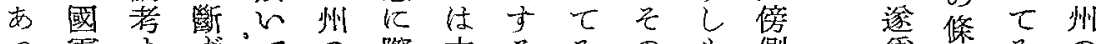

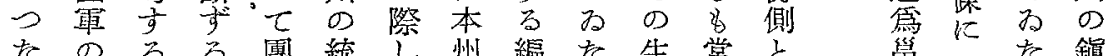
たのるる團統し州編た生常々 兽に灰

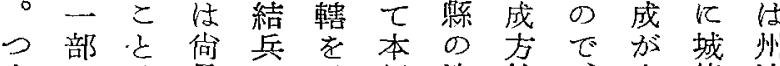
まを禹示州治針、先傍治 り应困であす縣城が長亏゙の傍 そし難苛つ名のを持く城子側 のてでるたの治防續此傍弟の 內るあ。とと城政せのにの意 容老方兩斷云を学名初み味 はのが者じへ防当れを机にで 同に、のてる衙にた保つ限亦 じ對一關差。せ在のつ在らる

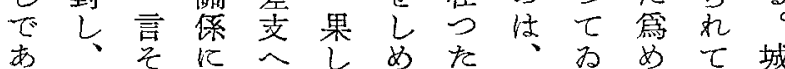
つ城の就なてたの的市傍 た傍大々い然城でのの此たと がは要て。傍あ活でのわは 州をは然ばはる。用あ名的 國 0 述更占城、。目方名でち 家刺心にば傍賞本的う学は州 的史る唐城在然州が。附吉縣

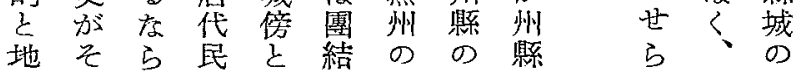
州 こ防 電皇團 声枈結 遂方 の 奔藤索 州記

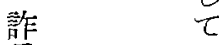
密 \% 整茟告 


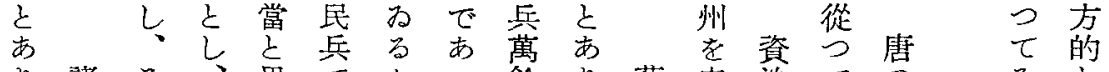

り諸そ、思でかつ餘り、蔡守治ての市

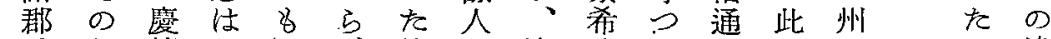
特兵部緒 れ地、筈を洛德て 鑑所住違

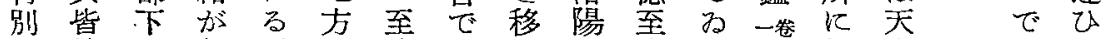

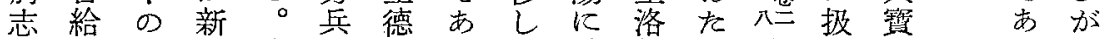
願糧兵規次た江隨陽史唐方元公市

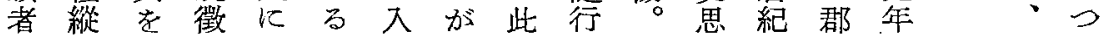
以遣處兵同城つ、水し安明 - 兵三 份た

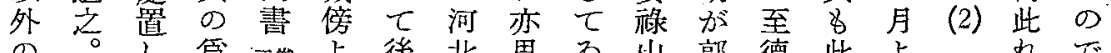

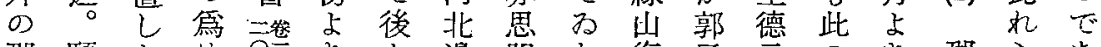

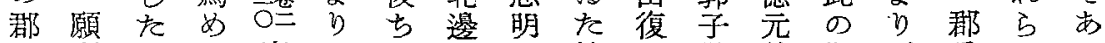

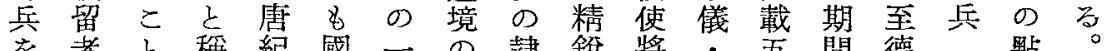

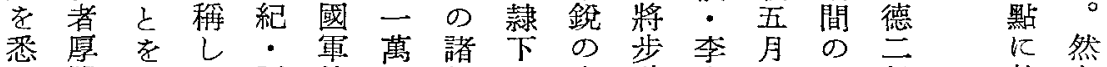

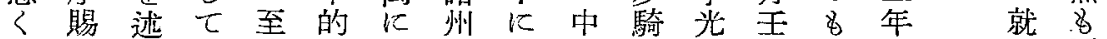

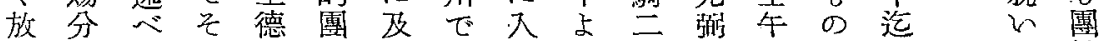

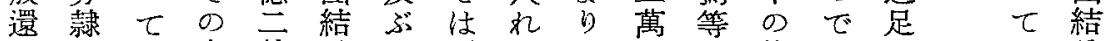
し諸實 載 兵郡 團た 二人民條あ加住兵 た營住条に兵結々萬。破にるけ後は 之。史 $の$ 下庄兵云を北方、文城

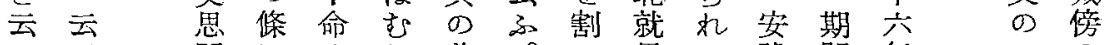

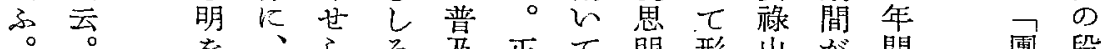
此圖安 れ 團 が兵北勢出短に閏結階 の 5 璴 郡緒の 兵覺征せ使く市を゙た 兵 め の が亡

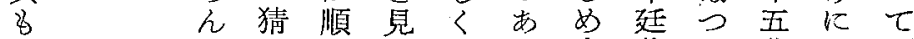

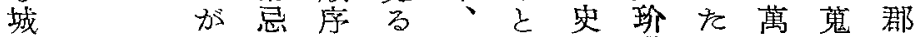

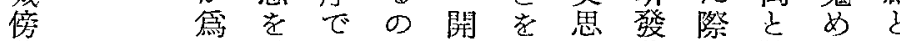

若

L

は

專

結

兵

㲾

民

兵

L

て

卧

兮

め受あが元承明范の號得改

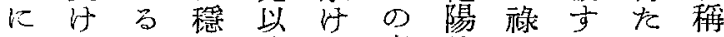
遣た か 當 後て麼等山无せ し史らで年州下郡の精のら た思、あを軍に兵處銳用れ 阿明やら降を入萬鱼を例 史がはうる衛犯餘を率々刺

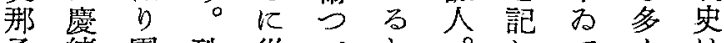

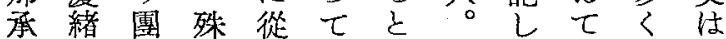
磨に結につわ共助七洛は太 - 叛兵他てた思陽な守

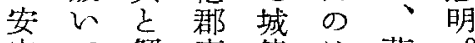
守七解 應傍は范 忠唐卞援に城榎 等 朝 る の 取 傍 をにの出つ证 逆投が兵ては に降上代團等 抑せり同つ結 留九適して兵郡

化 $w$ 進○改 期少 L $\quad$ b

發 展 そ 段机 階 加 ○ 5 條犯 出 論 た 双 8 क 9 るで 豫

定 發 で 展 あ史 る 的 深 留机 留疗 $\infty$ to

幽 々 閣 俰 を 


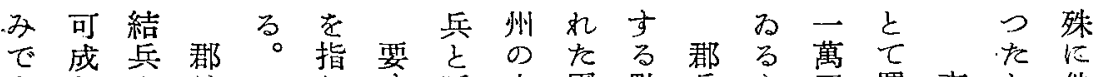

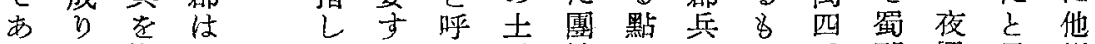
る盛指天死呑民結でをの千郡蜀思州

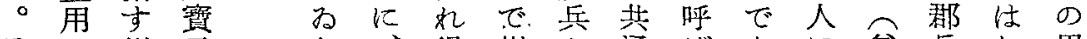

兵せ州元を、得州占通ばあに益兵れ 用

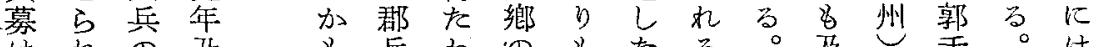

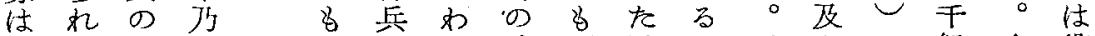

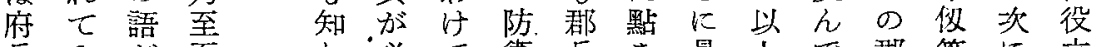

兵わ放必で衞兵を・最上で郡等・に立

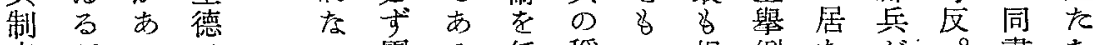

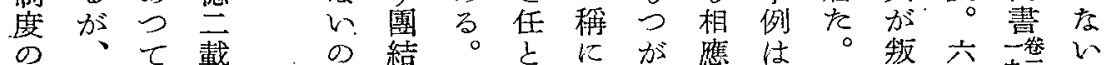

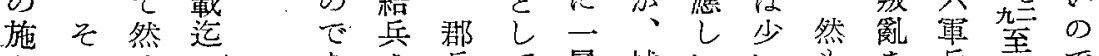

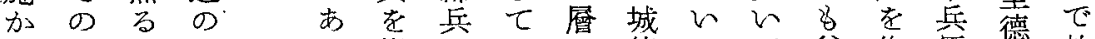

狄內 可州指 が る

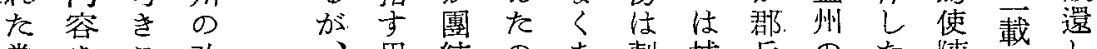

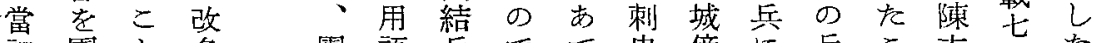

初團と名團語兵でて史傍に兵こ立月月た

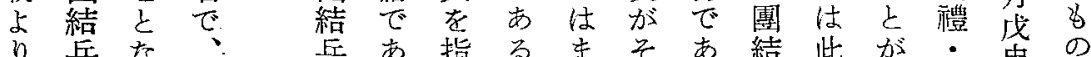

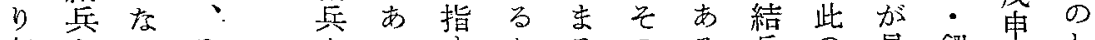

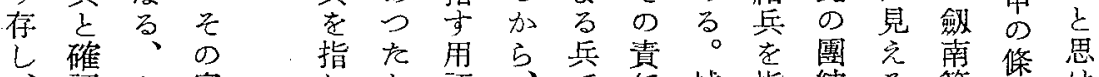

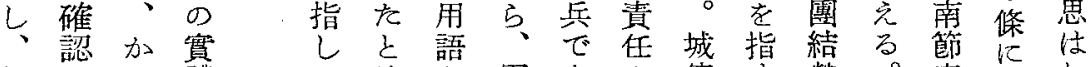

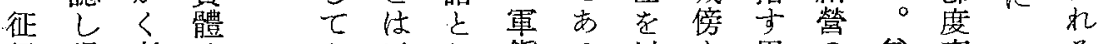

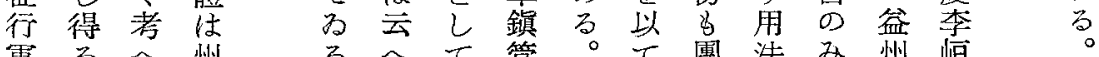

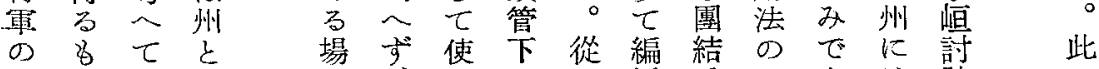

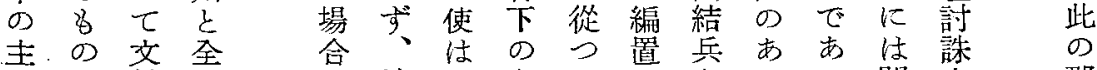

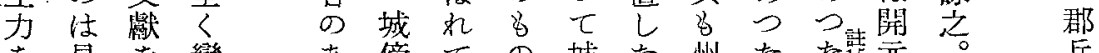

を見を變 あ傍て の城艺州たた元。兵

構出漁 り 兵

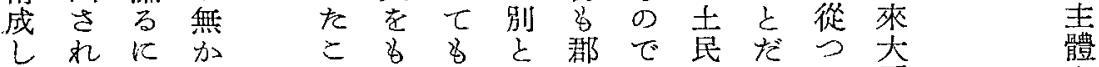

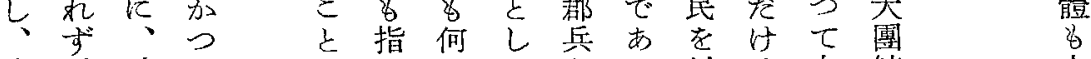

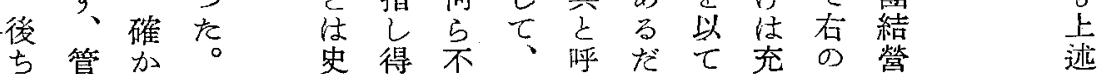

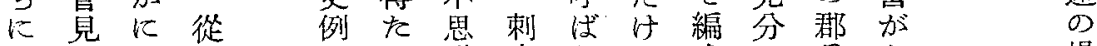

はの州つ之議史如に成に兵捛場

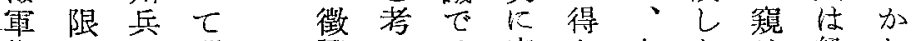

鎮り の 郡 證へは率た中就れ、

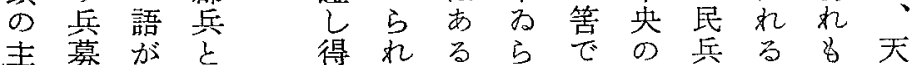

主募 が と 存 同 る 得れ る

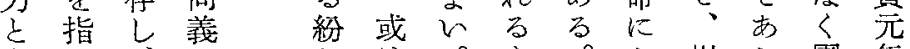

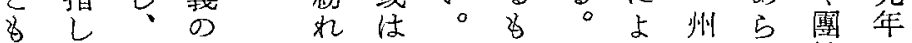

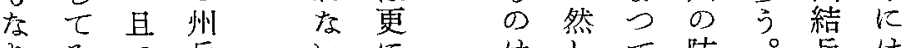

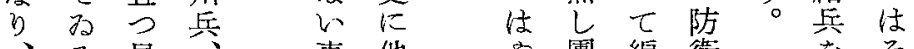

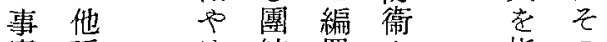

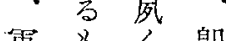

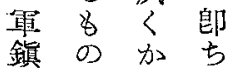

の $の$ 嘈

實 種

は結置を指の

あ

合

局

理

由

ts

嫥

結

大

あ 


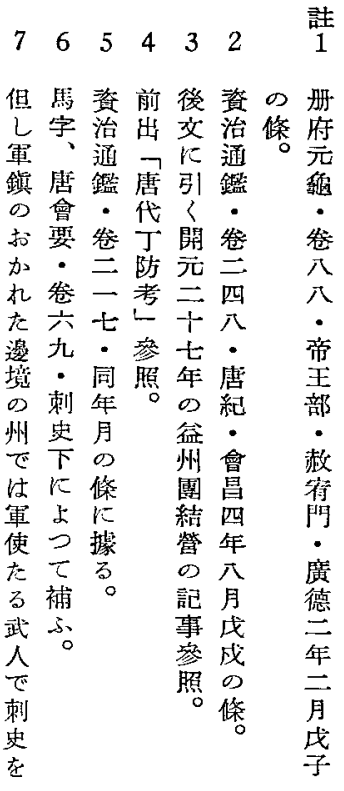

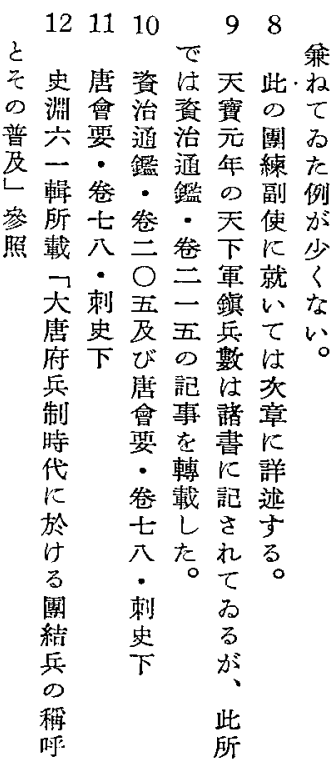

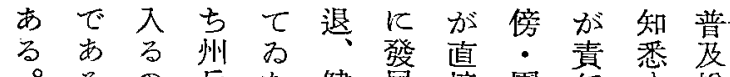

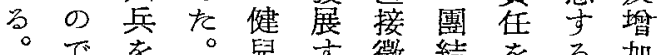
でを兒す徴結をる加 但あ以從のる募兵負をと しるて $っ$ 發としのつ得共 州分團 $\tau$ 展共、發七机

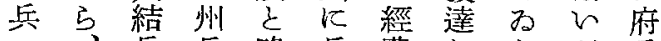
$\therefore$ 兵兵略兵費 した が兵

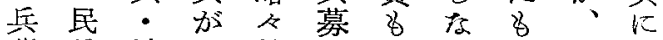
募兵城兵並飞中心代 - 傍募行代央以の央D

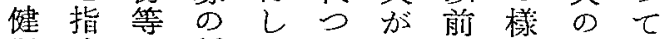
兒军の稱てて負にで割櫋

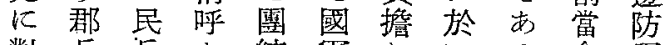
對兵兵加結 電しいる命軍 吉 $の$ を 兵 $の \tau \tau$ 令 る 使指城の 主る州さに花 如用稱傍發力兵基形 上かし・展と兵がしいと の 5 得團孞なを兵たてな 所、結 あつ健募意州つ 見州期兵り、た兒を味㤎て 兵間に、。指で强柿 未移兵兵云稱兵制た。

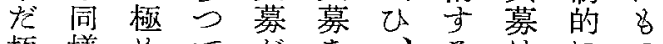

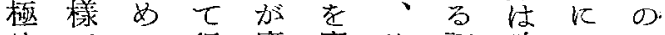
めでて 行䉀廢此語確丁で てあ短つせ步れと男あ

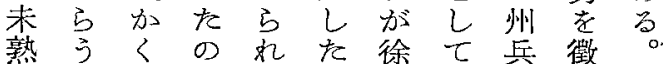

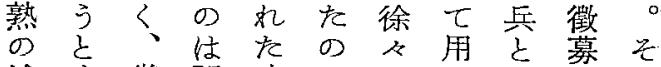

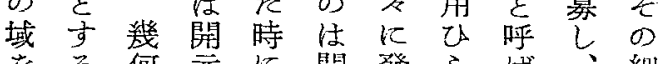
をる何元に開發ら壮、細 出推8 8 は 元達れ视々加 で 測な本團二した得のな ず、はく年 結十て の可裝內 殆し頃兵五長はきき㣁容 詳んてのは年充賞要・蛙 確ご州こ健でへ然素給末 な許がと兒あ征と與芘 究さ郡でにるし云有や究 明れ亡あ次。健入了家明 は去改つ注兒る。兵族せ

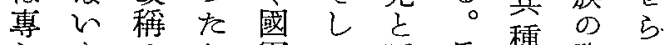
ら者軍七呼兵種凟好 今 $の$ 思 $の$ 此募で助て 後之机 は要 $の$ れ の見衣如素兵る外つ至店 課る天ると募職にたる心 題可寶。なの業中迄の できに毁つ蒸兵央城州で 


\begin{tabular}{|c|c|c|c|c|c|c|c|c|c|c|c|c|c|c|c|}
\hline 回 & 州 & 置 & 關 & & & $w$ & の & の & 從 & & 程 & 己 & & & \\
\hline 州 & 閣闻 & 加 & 內 & 團 & & $\Phi$ & 爾 & 發 & $?$ & 團 & 等 & れ & 團 & & 1413 \\
\hline & 多 & $\frac{\pi}{\tau}$ & 河 & $\begin{array}{l}\text { 結 } \\
\text { 兵 }\end{array}$ & & で & $\begin{array}{l}\text { 者 } \\
\text { を }\end{array}$ & $\begin{array}{l}\text { 過 } \\
\text { }\end{array}$ & 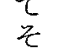 & $\begin{array}{l}\text { 結 } \\
\text { 兵 }\end{array}$ & $\stackrel{\text { D }}{\equiv}$ & $\begin{array}{l}\tau \\
\text { d }\end{array}$ & $\begin{array}{l}\text { 結 } \\
\text { 兵 }\end{array}$ & & 資資 \\
\hline 併 & $\infty$ & ๖ & 東 & は & & 敢 & - & 程 & D & क & 點 & 5 & $\widehat{\omega}$ & & 治 治 \\
\hline & 會 & t & - & 先 & & $\tau$ & 括 & $\sigma$ & 普 & 名 & 力 & 徐 & 制 & & 鑑 \\
\hline$\tau$ & 州 & 州 & 劍 & 5 & & 制 & $\frac{1}{9}$ & 問 & 及 & が & 5 & 4 & 度 & & \\
\hline & & $\varepsilon$ & 南 & 河 & & 度 & る & 題 & 增 & 交 & 考 & $k$ & は & $\Xi$ & 卷䆔 \\
\hline & 矲 & 2 & 諸 & 北 & I & の & の & $\varepsilon$ & 加 & 獻 & 說 & 生 & 唐 & & $=$ \\
\hline & 石 & $\tau$ & 道 & - & & 發 & が & L & $\infty$ & $k$ & 9 & 成 & 初 & 團 & $\overrightarrow{0}$ \\
\hline 州 & $\infty$ & そ & $\infty$ & 河 & 地 & 達 & 最 & $\tau$ & 跡 & 始 & る & 發 & $k$ & 結 & 四 九 \\
\hline & 部 & 0 & 邊 & 南 & 減 & を & 3 & 扱 & 考 & 見 & & 達 & は & 兵 & \\
\hline & $\therefore$ & 名 & 境 & 道 & 的 & 些 & 使 & $\delta_{x}$ & 训 & 9 & & L & 存 & $\infty$ & \\
\hline & 厚了' & t & 諸 & $k$ & 晋 & 所 & 相 & 格 & 得 & 3 & & 7 & $w_{0}$ & 發 & + \\
\hline$v$ & 洮 & 獻 & 及 & 最 & & - & あ & $w$ & 3 & は & & D & 大 & 達 & $\overrightarrow{\text { 月 }}$ \\
\hline ts & . & $k$ & び & L & 概 & 括 & る & $\circ$ & $\omega$ & & & で & 唐 & & $\sigma$ \\
\hline & 凉 & 確 & 宗 & & 要 & L & が & 起 & 8 & 從 & & あ & 0 & & 條 \\
\hline 此 & $\therefore$ & 認 & 兆 & 次 & & $\tau$ & 然 & 原 & 些 & 來 & & る。 & 世 & & $\begin{array}{l}k \\
\downarrow\end{array}$ \\
\hline & 舟 & 得 & 同 & T & & 更 & 然 & 閭 & 年 & $k$ & & 此 & 制 & & る \\
\hline & 沙 & 3 & • & 河 & & 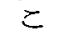 & 團 & 題 & 以 & 指 & & 0 & 霸 & & \\
\hline & 西 & の & 華 & 南 & & $\varepsilon$ & 結 & $\frac{z}{c}$ & 後 & 摘 & & 團 & $k$ & & \\
\hline & 西 & は & $\dot{y}$ & 道 & & k & 兵 & 制 & 作 & एँ & & 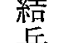 & 瀿 & & \\
\hline & F & 河 & 等 & 裁 & & t & 發 & 皦 & 禁 & $\frac{b}{\not k}$ & & 紊 & is & & \\
\hline & 州 & 北 & 首 & 減 & & & 逵 & 犎 & $\tau$ & $\tau$ & & 生 & び & & \\
\hline & & 0 & 都 & せ & & 起 & を & $の$ & で & わ & & 成 & が & & \\
\hline & 器 & 恒 & 附 & $\zeta$ & & 原 & 論 & 問 & あ & 壳 & & 發 & 入 & & 15 \\
\hline & 商 & 定 & $\frac{\text { 近 }}{\sigma}$ & れ & & $\begin{array}{l}\infty \\
\text { 問 }\end{array}$ & $\frac{9}{3}$ & 題 & 2 & 如 & & $\frac{\text { 泘 }}{z}$ & ? & & \\
\hline & क & N & 四 & 河 & & 題 & $k$ & は & 此 & $\checkmark$ & & $\xi$ & 北 & & \\
\hline & 益 & 易 & 府 & 北 & & は & 當 & 互 & 9 & 則 & & $\infty$ & 方 & & $y$ \\
\hline & & & 州 & 道 & & 章 & $?$ & $k$ & 年 & 天 & & 普 & 民 & & $\mathrm{B}$ \\
\hline & 翼 & 莫 & k & 0 & & を & $\tau$ & 密 & 以 & 武 & & 及 & 族 & & \\
\hline & • & $\therefore$ & 晋 & 邊 & & 更 & 制 & 接 & 前 & 后 & & & D & & 章 \\
\hline & 茂 & 滄 & 及 & 境 & & め & 度 & な & 0 & の & & 兵 & 反 & & $k$ \\
\hline & $\therefore$ & - & L & $k$ & & $\tau$ & 上 & 閭 & 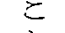 & 萬 & & 數 & 蒰 & & \\
\hline & 黎 & 瀛。 & $\cdot t_{0}$ & 集 & & 引! & $\infty$ & 係 & $\frac{k}{d}$ & 歲 & & $\infty$ & $k$ & & 逃 \\
\hline & 雅 & $\dot{4}$ & 閏 & + & & 簤 & 蔆 & 有 & 就 & $\frac{\text { 迪 }}{天}$ & & 形 & 遭 & & \\
\hline & $a_{12}$ & 等 & $\bar{\pi}$ & $\xi$ & & 專 & を & 5 & 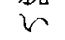 & 元 & & & $\tau$ & & \\
\hline & Iㄱ & 七 & $\cdot$ & dz & & 考 & 取 & & $\tau$ & 年 & & 及 & 受 & & \\
\hline & 等 & 州 & F & & & $\frac{1}{9}$ & 除 & 取 & は & 2 & & び & 身 & & \\
\hline & 空 & 河 & $\begin{array}{l}\text { 翼 } \\
\end{array}$ & 開 & & 方 & $\stackrel{\leq}{\leq}$ & 敃 & $\begin{array}{l}c \\
\infty \\
\infty\end{array}$ & 空 & & $\begin{array}{l}\text { 製 } \\
\text { 度 }\end{array}$ & $\begin{array}{l}0 \\
\text { 罌 }\end{array}$ & & \\
\hline & & 南 & 代 & 以 & & $\begin{array}{l}\text { 祭 } \\
\text { 定 }\end{array}$ & $\bar{c}$ & $\infty$ & 起 & 亲 & & a & 防 & & \\
\hline & 首 & $\infty$ & $k$ & 後 & & で & 8 & 上 & 原 & $\smile$ & & 生 & 政 & & \\
\hline & 都 & 登 & 畓 & & & あ & 穩 & か & 及 & で & & 盛 & 寽 & & \\
\hline & 阥 & $\dot{0}$ & 結 & 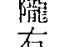 & & b & 富 & 5 & 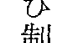 & $\begin{array}{l}\text { क } \\
b\end{array}$ & & 鍳 & 立 & & \\
\hline & の & $\stackrel{\text { 承 }}{=}$ & 兵 & 名 & & & な & 此 & 度 & & & 過 & $\bar{k}$ & & \\
\hline
\end{tabular}




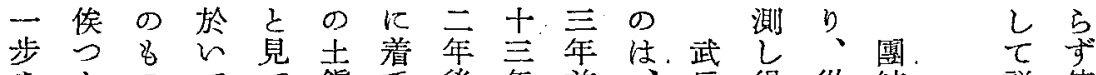

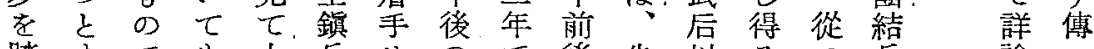
踏卞でる大兵せので後先以るつ兵論令

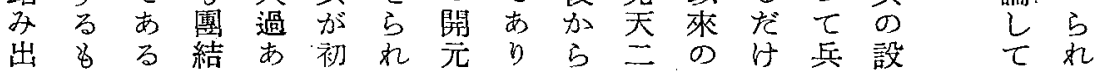

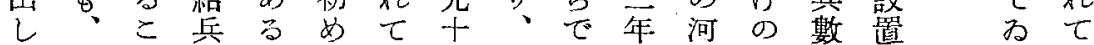
たととのまて河七開市北史の地るる

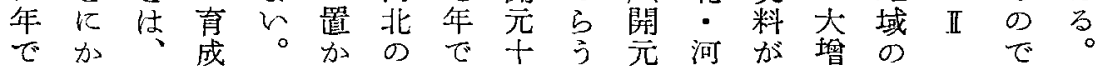

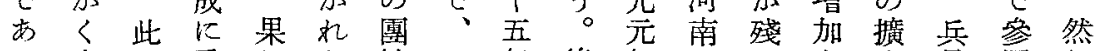
つ交れ乘した結加年後年のさ它大員照し

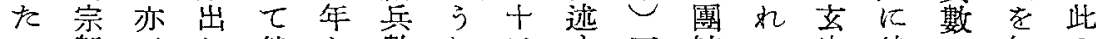
$乙$ 即三し然と數し二す正結 $て$ 宗件

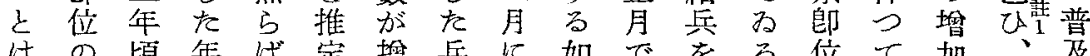

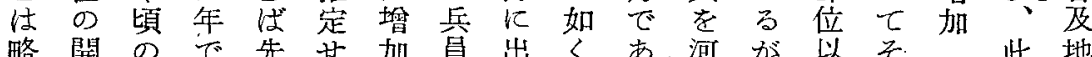

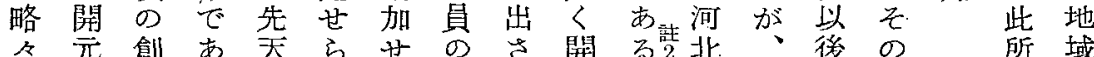

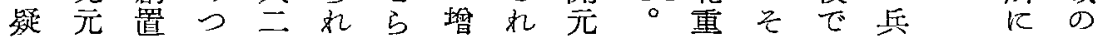
ひ年でた年るれ募た十此點れ南貝は詳 あがあこ市の初撗河一の主以つ數—細

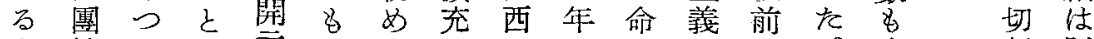

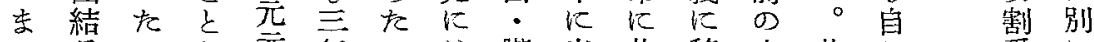
、兵のな元年のは.隴出基移十此 5 愛に

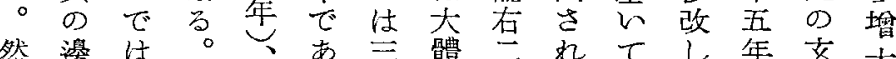

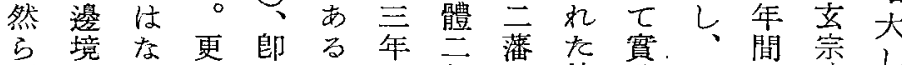

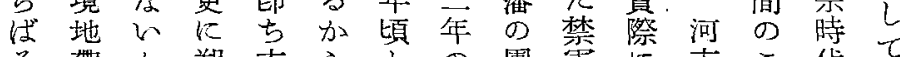

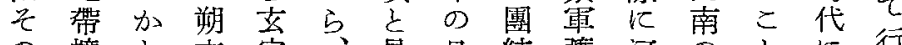
の擴と方宗見日結磺河のとに行

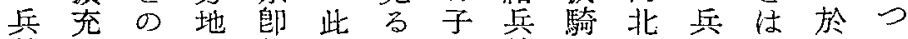

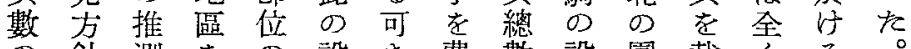
の 針 測をの設き費 數 設 團载くるる。

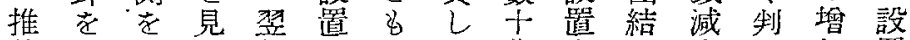
移決抱る年命のて萬命兵主 $匚$ 加置

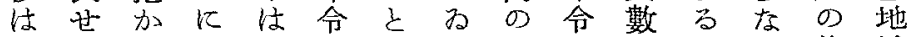

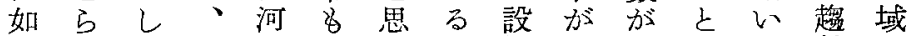
何れめそ北三注置具垣共。勢 をるの年和方命現加に控 年。唯み前る 、令华世河之持

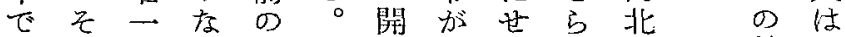
あののら先所元具方れ諸員玄 り賞團ず兵で元現れ始州數宗 、否結 $\therefore$ 三河年化机めの 翌は兵河年西の せ

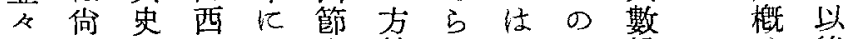
三今料・出度針れ主は增注後 年後が隴さ使轉初年恐加或に がの 開右れ管換め後らををる顯 實補元方た帛がたのく命程著 現考七面る 沙實の開開じ度で 第に年にの州行多元元た推あ 


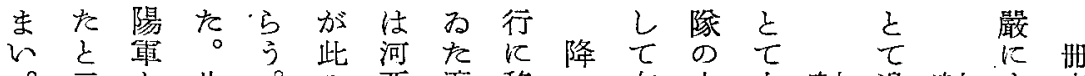

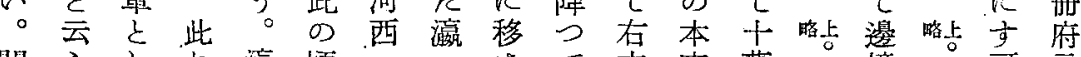

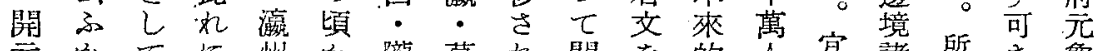

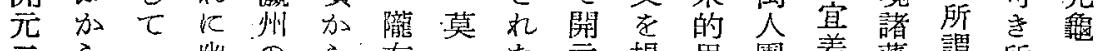
云 5 萬

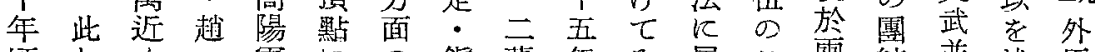

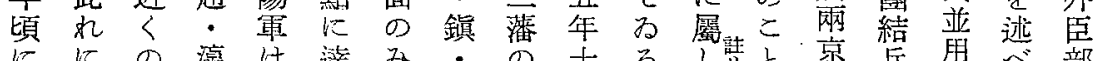

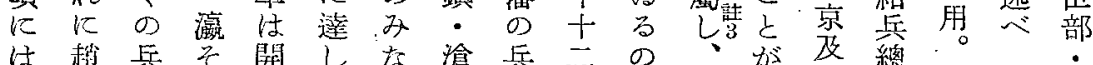

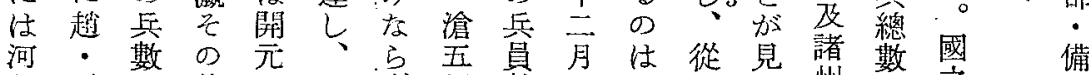

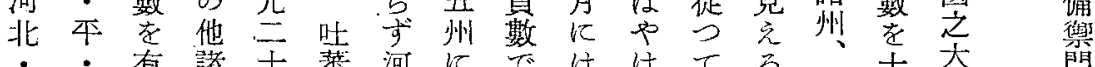

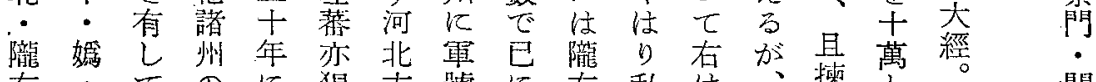

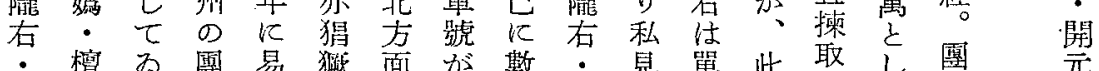

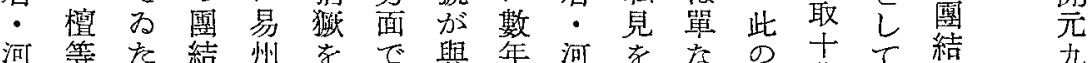

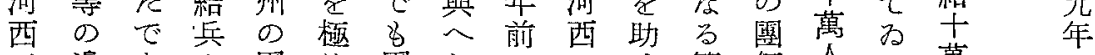

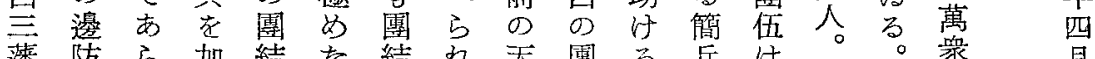

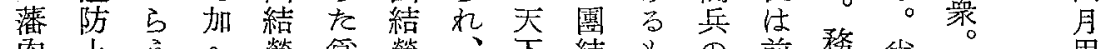

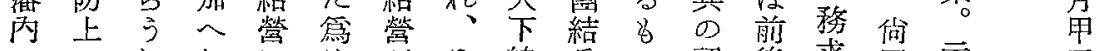
の

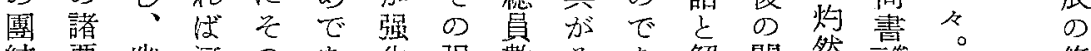

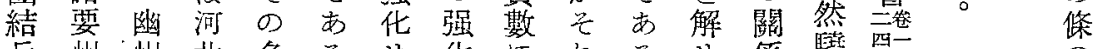

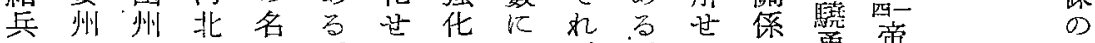
の 0 で, の を 敃霜 總移河犯力敵犯 で結 安數名東 たがし 六 已兵串学机。時注て萬 にをの恐、朔代がわと

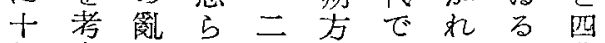
年虑にく干市市。萬

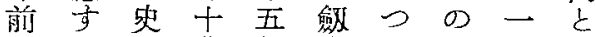
のれ思萬年南たは方に 十ば明をの等と開河墦 萬 $\infty$ 前兵穴云北貝 に十配後力名公十皇 豆萬下华恐古四於命 倍のに七各ら年いぜ

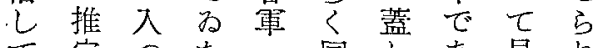

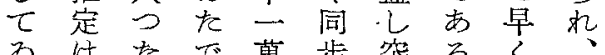

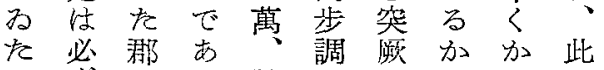

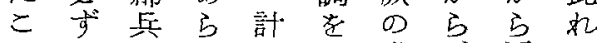

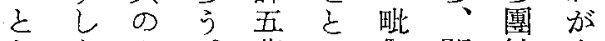

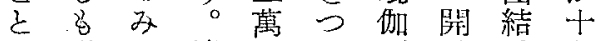
な過で涴をて可元兵七 る大約州掖 乃汗十学

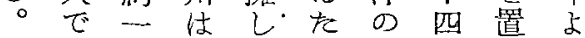
此あ蕮舊てで活五いる のる居罱居あ動年て 實

詔

ic

检

南

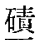

西

譬

队

躍

河

東

㑸

北

檤

の

兵

防 


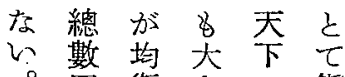

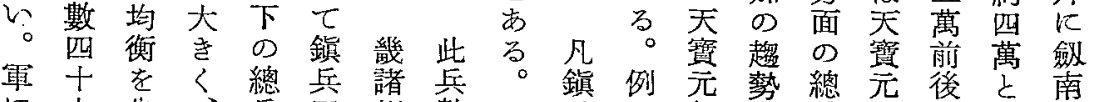

飞杂失、兵四州數そ兵年年體年になる 萬高殊數十喥。乙四資の辿的飞及る推

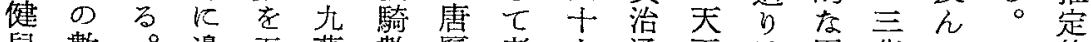
兒嘍。邊五萬數糜考旮通下續團萬で此約 字加兵十は忌所異萬鑑軍㺭結五居れ外にく莎健耳載に人に鎮儿兵百たに萬

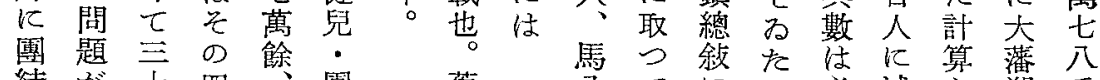

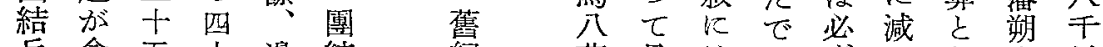

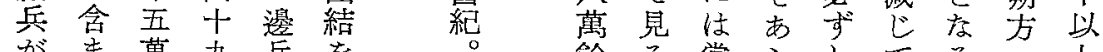

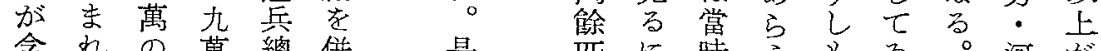
含れ の 萬總併是远飞時方名わ。河が

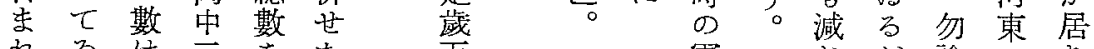

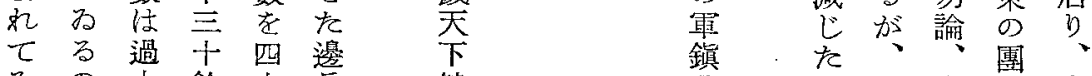
わ大餘十兵健分此大結京 るでな萬杂の十兒度れざ兵畿

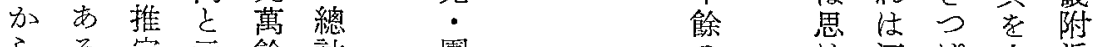

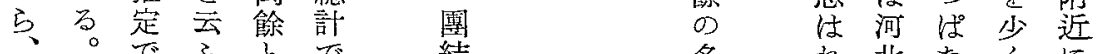

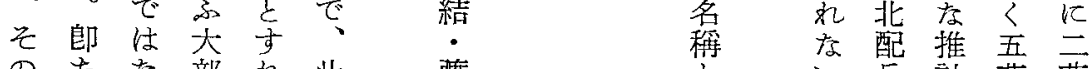

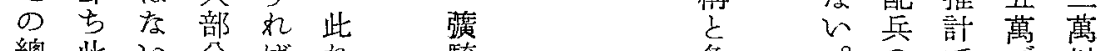

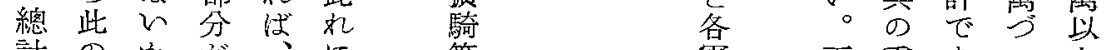

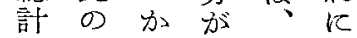
た四子國此禁 る十の結 れ電 四兄危兵にの 十萬惧忩對 演 九はがあす騎

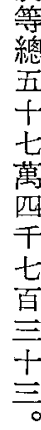
萬八抱つるを の十加支 團 加 中 餘 れこ。結 算

化算当兵岳 は鎳がなのれ

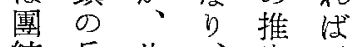
結 兵此、定五 兵力れ明總十

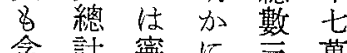

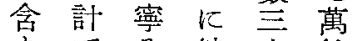
王で弓健十筷 れ、團兒五它 全結。萬南

为邀数囷前口 了防志結後た 出兵方兵任と

力多飳声彼

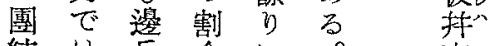
結は兵合比。京 天重西口上

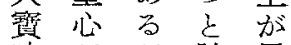
時が加踏居 代更觉赏 入極. 兽的河 四数分阌尔傮南

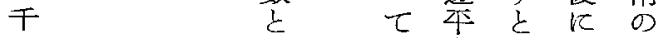
旨茢虚踓土登

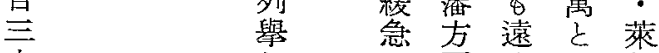
ᄂ. の面くな州 最差推要? 合

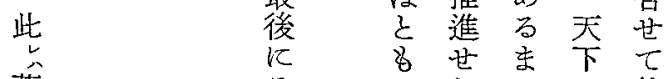
蓋

訾

管

晸 名占心の 約

$<$ 员。署 飞た河結 $\overline{7}$ ᄂ第北兵㤎 七五楾居 やで・軍數て は・の注通 增河吾要言大 
の三傳の怙人䥊略る五三亲元合總に兵 で割芓約、に等確霜手守年先十が數はに

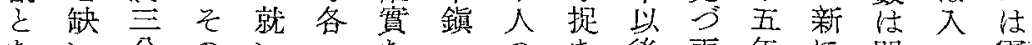

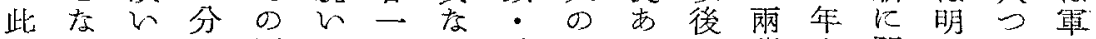
のる 率。にが結表存は方置、設の二題でるに に沿す灀兵を在七仵そ置天月となな屬

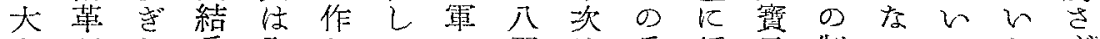

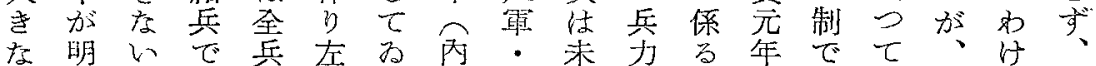

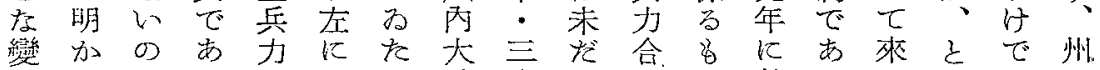

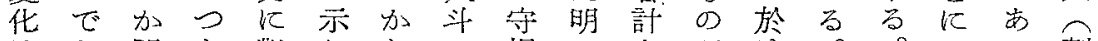

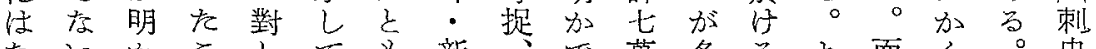
な

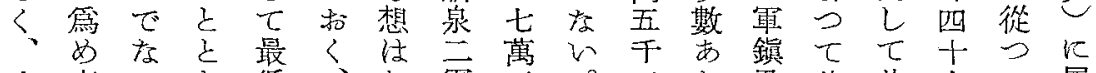

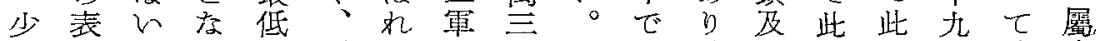

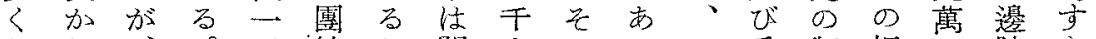
とら、。五結 が開人こると兵制振を防 8

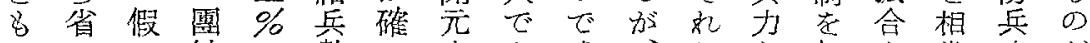

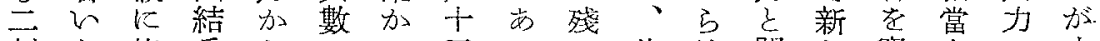

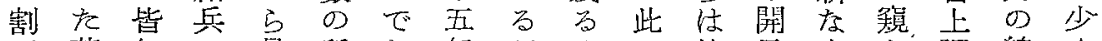

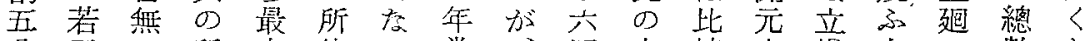

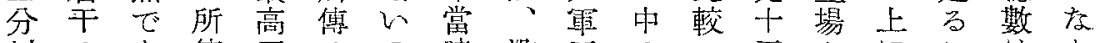
以のあ傳五のの時治五の五少にこはか

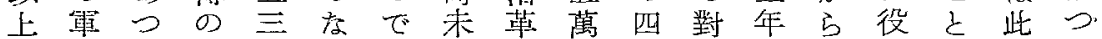

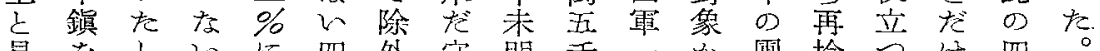

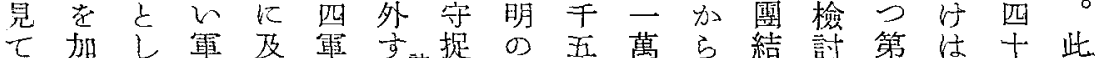

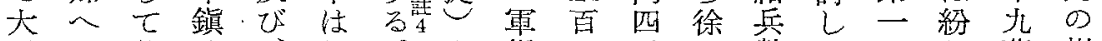

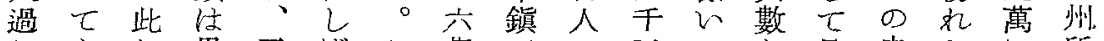

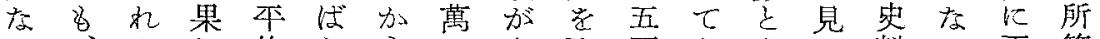

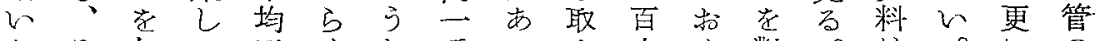

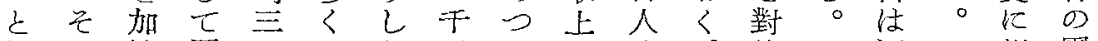

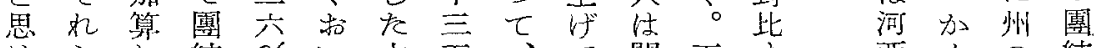

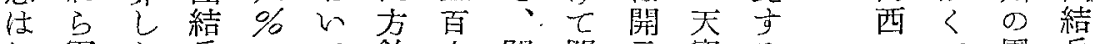

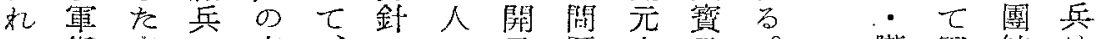

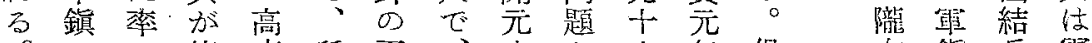
の皆率所下立六年但右鎮兵電

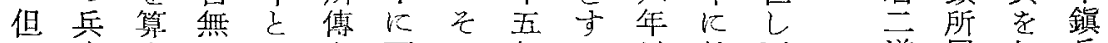
乙力出で索あ兩 D年名以於天道屬加兵

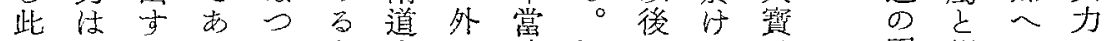

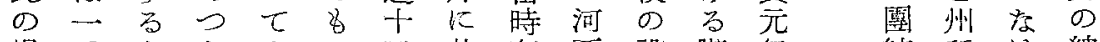

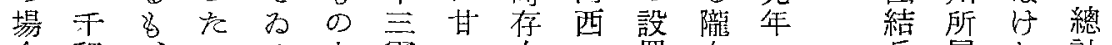

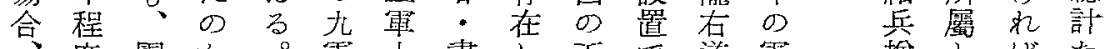

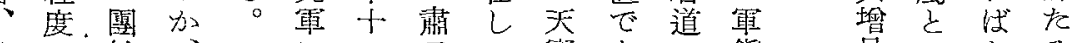
各の結、つに一元七乵支の鎮員の存る

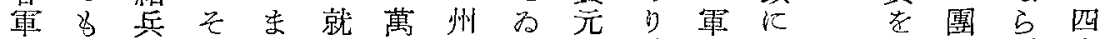

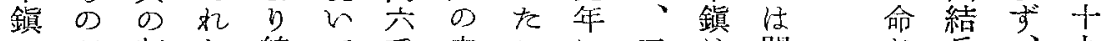
のが割と總てテ守こに三は開兵、元

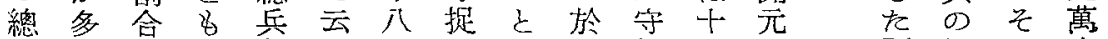
兵い住所數 


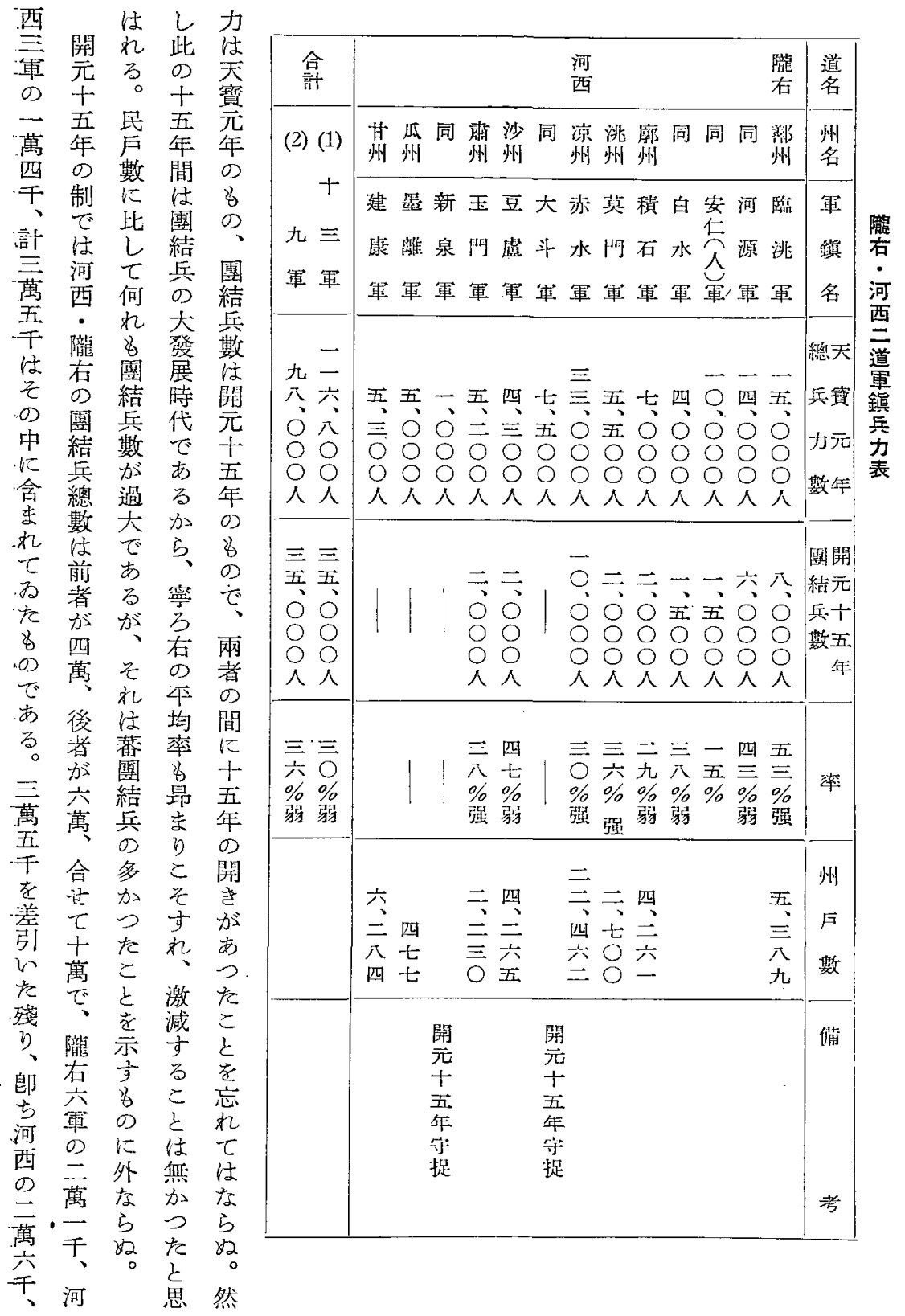




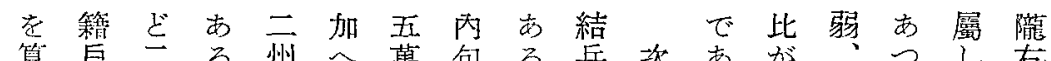

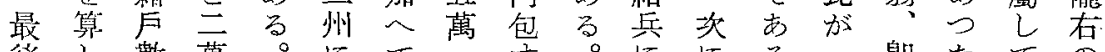

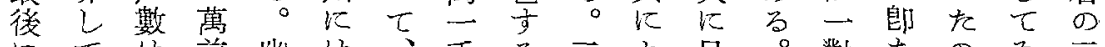

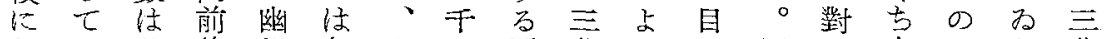

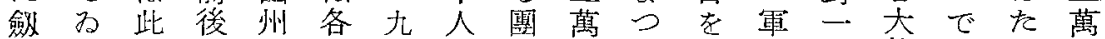

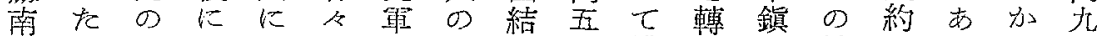

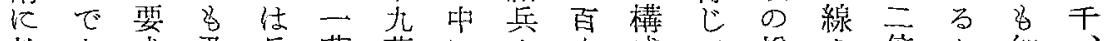
就あ求及兵萬萬にを人成元增壳倍加知、

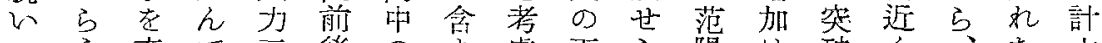
てう充で三後の类虑天゙陽は破く、な六

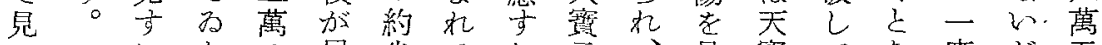

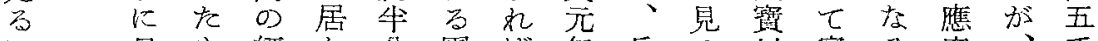

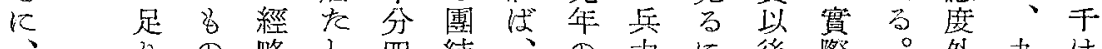

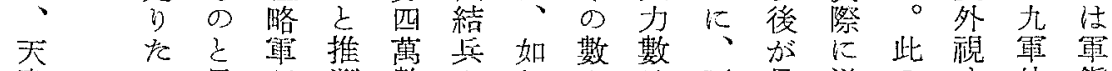

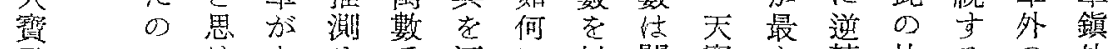

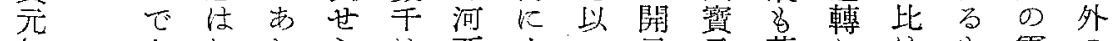

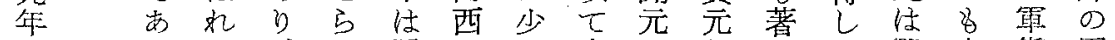

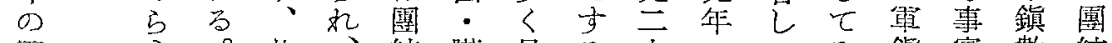

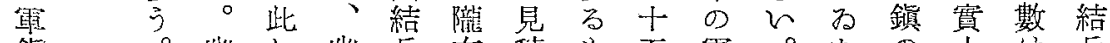

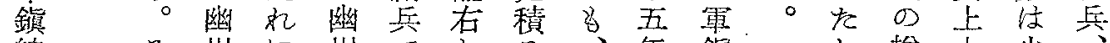
總そ州に州で当、年鎮

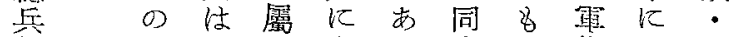

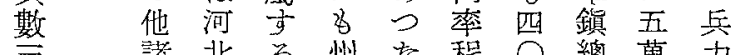

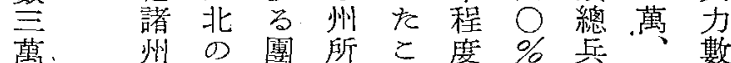

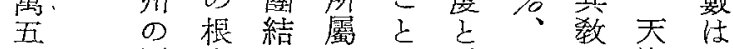

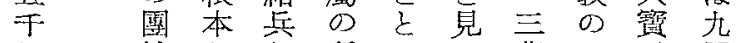
餘結 と文所な如葛三元雷 二 兵して州謂 る

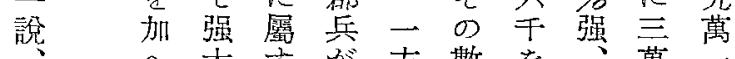

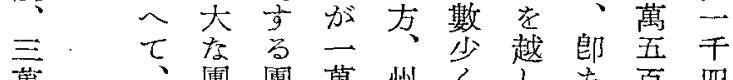

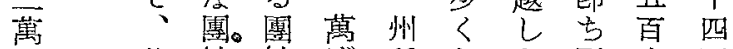
三此結 結 ば 所々考人西

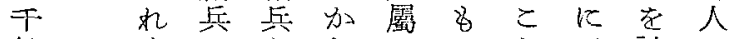
餘亦をりの一と三部て

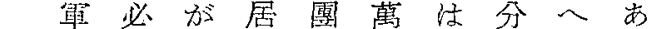
飞鎮要居た結敭絕一たる

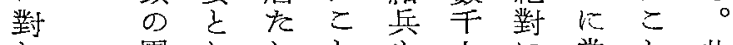

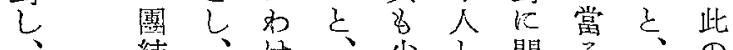

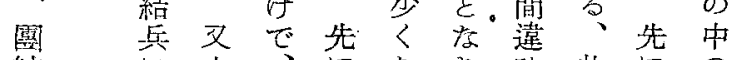
結に六、になる。此にの 兵匹萬彼論少、疗考五 た 敵 七是述つ此いに說軍

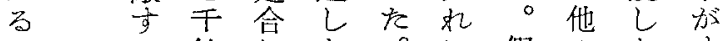

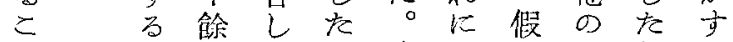

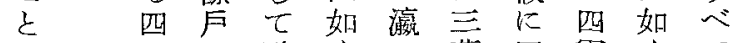
の 五 0 殆く $<$ 萬四军 $<\tau$ 明萬載んで越をを電が。で.䨋

は㴰大少設 想之具方 は 共談つ州 机茩そ所 夌逆はの屬 以索兵

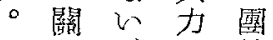
此俰、注結 のに雷何兵 十 㬍 鑥 れて 五 ずの \& あ 年可国殆 つ 間き結んた ○性 兵 ご。 霜質 と一或 鉷 0 州二住 の 8 0 千 此 增 の 踾程 加で結度中 はあ 兵の $の$ そると小若 加 の 規早 程、對 模は 想然比な 九 ししは名電 <天一の外 店揑、ばの 初八公霜 年六り鎬 らの倍でに 


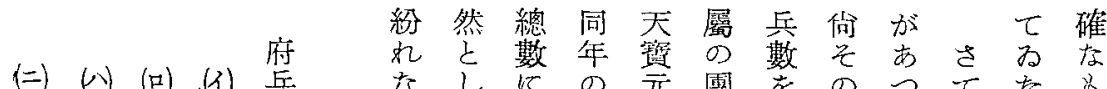

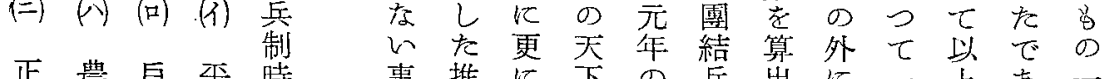
正農 替

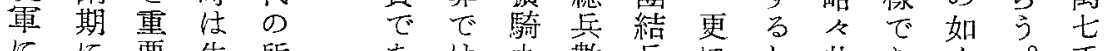
にに要生所市は數兵にと此なく。千

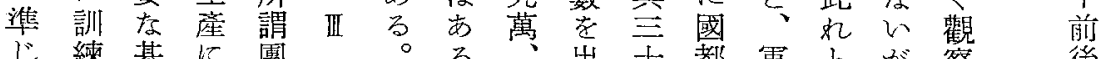

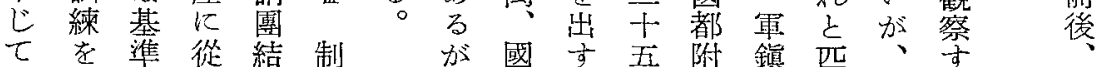

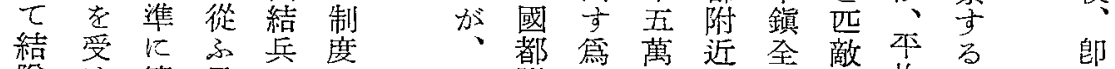

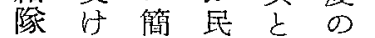
組、點 丁应發 織有入籍で展 $\begin{array}{llll}\text { せ 事 籍 } & \text { 段 } \\ \text { 己 } & \text { 階 }\end{array}$ 四附 $\phi$ 前 十近江後團 數る 全本 九 任結 四數兵軍約

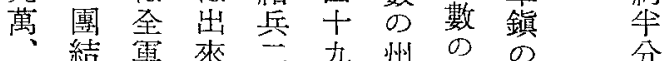
五兵鎮る萬萬所三中们 $+三 \omega$ 文餘焉四に后 七萬兵控を 約團割は

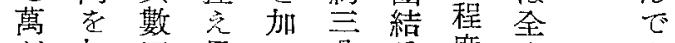
が加四自へ分兵度く

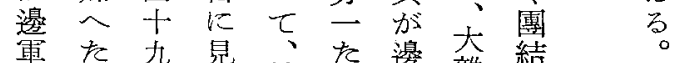
國約萬 た 總る 境 雜 兵結州

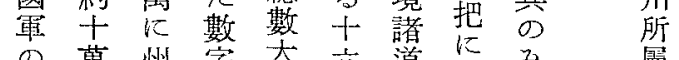
の葛州字大六道見み

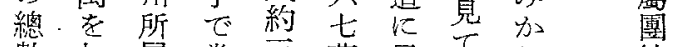

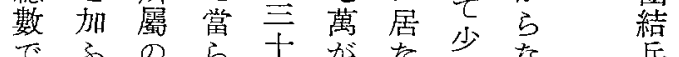

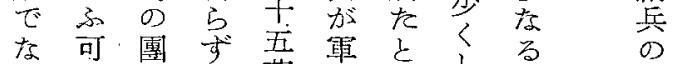

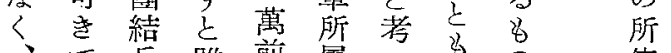
で兵雖前屬へ兰の傳

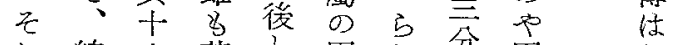
礼悤基豆團吅分團店

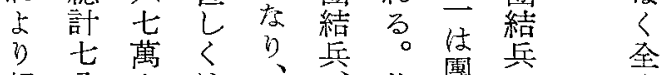

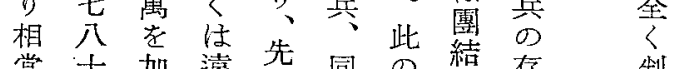
葍十加遠先同少結存制

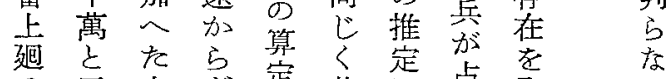
る 云大 ざ定此走占全的 數 ふ 約 る でこ 六推 略に

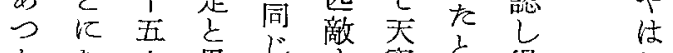

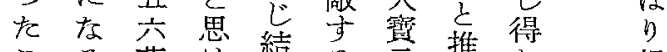
こる萬は愁る元推应相 之。 だ 頗邊 る

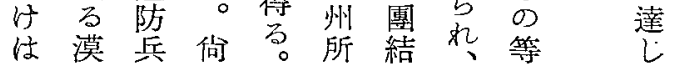


喘りを机しる

團ののた被

の 武 地自少鄉 國

規才方衞る士心

模に染。防歴

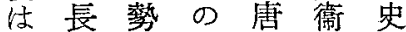

概け 力 河奕 $の$ を

社をを北大自通

數 者有諸混衞觀

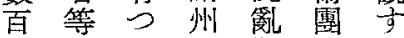

をを豪に期分る

り隊民於に結に

數長で讨於成

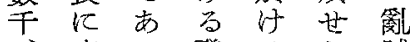

充つ發る ら賊

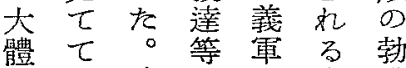

人る等內 呼合

程己住外等苦暴

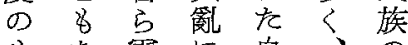

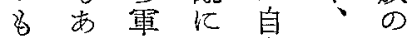

のるの對䒯更侵

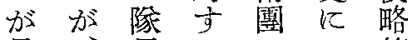

最、唇る の 加等

8 何 上自普分是

くにて 嘈發俈生

、乙先發達險の

時七陣達、狀 安

に多にの五態全

萬自立著代茫落

を衞つ例宋繼官

單團こで初續憲

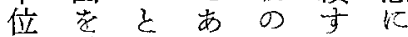

之動 8 る 契る

方加 あ 升主?

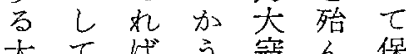

大て医う趈ん保

きょ、し掠 ど障

をた 孝た時例せ

のは徫に存れ

8 豪遊需於 ᄂ 難

あ民伙 の矤に以

つで或指方自事

をあ仕盙鄉衞態

がつ文者兵團 が

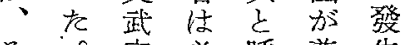

そ葛必㭔普生

和自上导依最主
な點保调迄所

以に凟落にの

。見助? は準(手（下）(村

所出 $の$ 枯必官

方さ制滅ず兵鄉武征電

此如度 0 户的保器賦鎮

のる。段生民の武免或

質 開階長兵非具除は

的施元を發で團その州

發行十辿展あ結の外に

（1）展地五つのつ兵他注屬

を域年て 戠た在の在し

鄉指 の 以推段。費營て

土摘幛 後移階 但少用中鄉

乙大 0 主分し方を者士

諰・河方を此資多身の

明兵西の經好助く糧電

純し數・がてはせ自を鋇

民の躘 制み團方辩官・

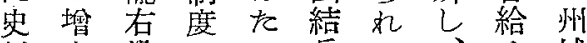

料大沿のと兵て、世域

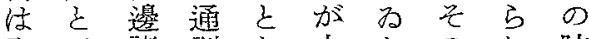

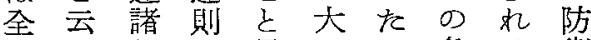

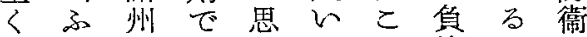

見量であはにと擔にに

出的壮名れ普々肪止當

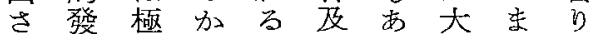

礼展度 ら。塯る沓つ

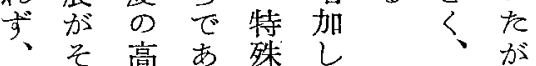

間の率る存衣市

接 質 點。制 開向

的的 兵變 度元 临

な發に 僄は・め

方展占の 别 天

法とつ一と頭

で無て 例し 時

推阆事はて 代

測 係 實、学

乙で 上武般中

七不后船心

行 D可時的

$<た$ 能代代し

外应に湈て

な在牀傳算見

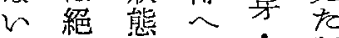

D對汇 ら立制

でに陷机生度

あ考兄文で

るへて る る れる 同花秃 


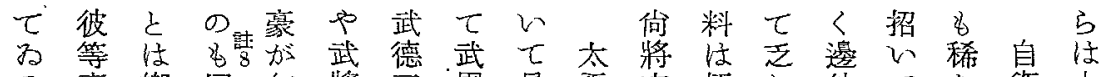

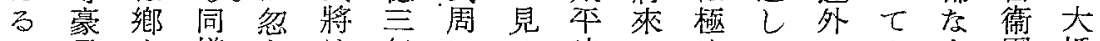

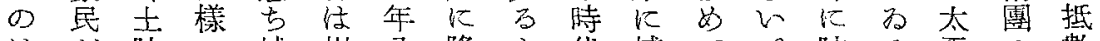

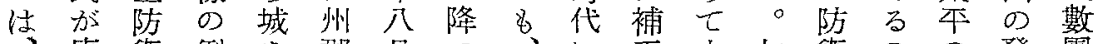

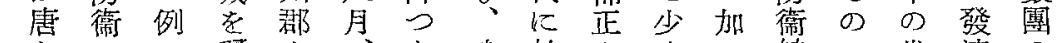

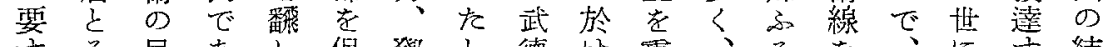

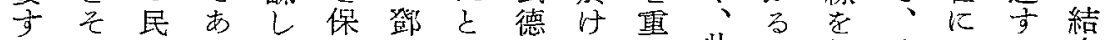

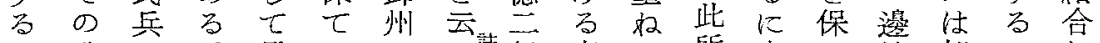

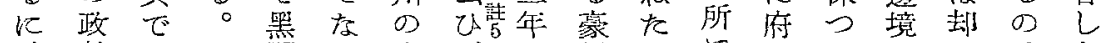

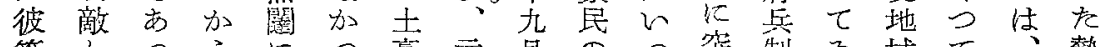

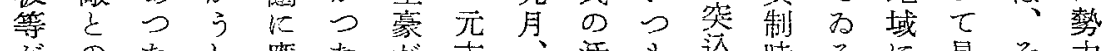

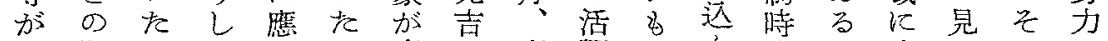

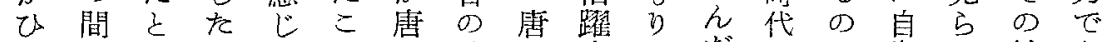

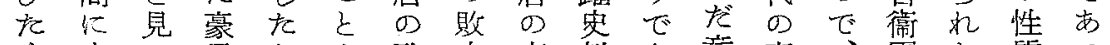

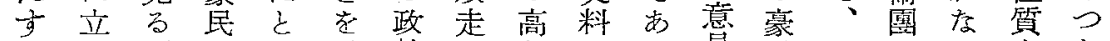

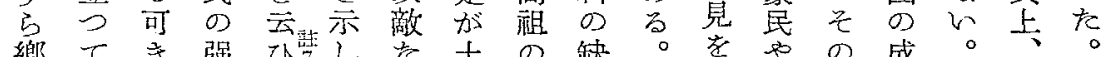
鄉てて き

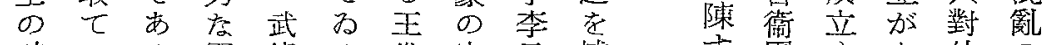

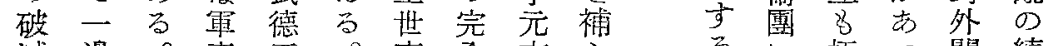

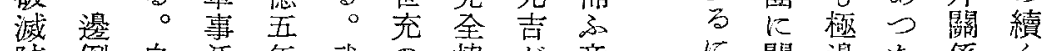
防倒自活年武 止的橖動 五德任力劉味 のな导肪月四命を武で

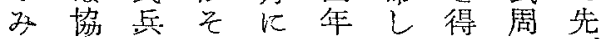
艺力㾁 念を㯖萃州二刺及 攻䧎

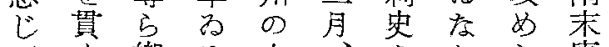

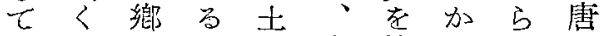
わこ士手蒙李揄つ如初 た $の$ 兵王世人たた 第应安に幹潵てこ太混

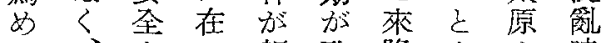
飞、を る 频政降をを時 外兩念 $を$ 将敵 $L-$ 逃代 忍者覑こ賀の在因げの らのとと拔 劉と出輩

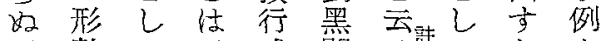

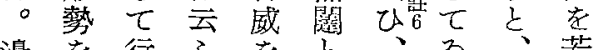

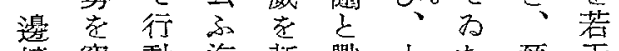

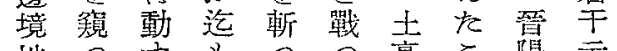

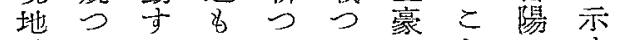

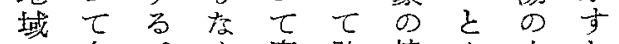

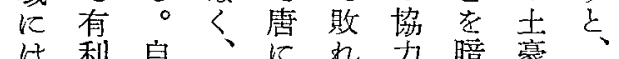

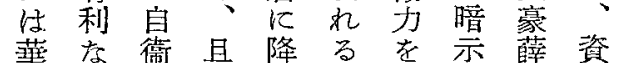
英側面つつゃ得し深治 のにをそを洛なてが通 間轉 率のと州々括城鑑 に附わ手あの官りをに 跨しる兵る土更、以就

るるに推於代 少篦止測

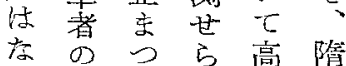
心研て次宗集 が究みるの噟 とはたが甈初

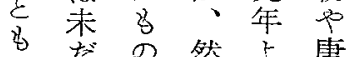
か だ の 今指放估受、吾 日 8 品身代 迄着さ地を深な

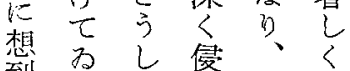
到な在势武 乙息后底 わ望受 以兵 るで關代後制

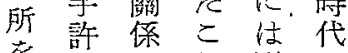
をに文形心 敢在史 勎如 七当科稀 のく 披蒐虂芯惡前 露 霜極、化後 ᄂ史めよをに 


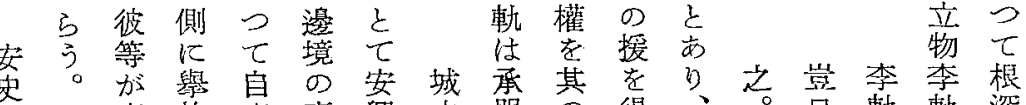

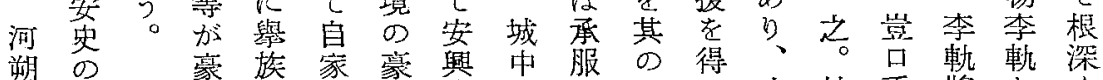

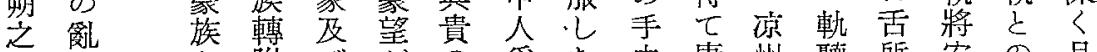

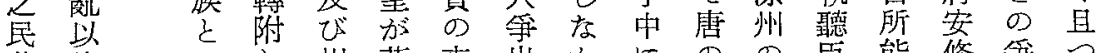
苦後 $-し$ 州曅來出加飞のの臣能修爭つ 战名體、鄉夷征就つ握李安固下仁を强

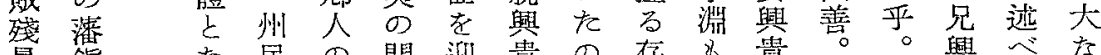

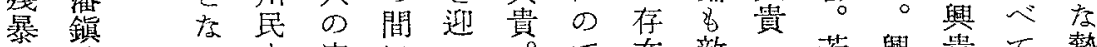

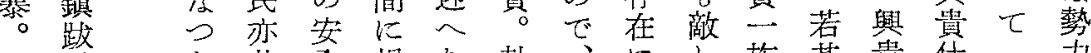

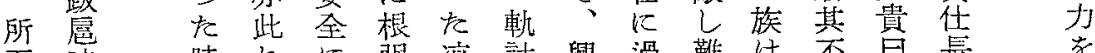
至時時れに强凉計興過難は不冒長を

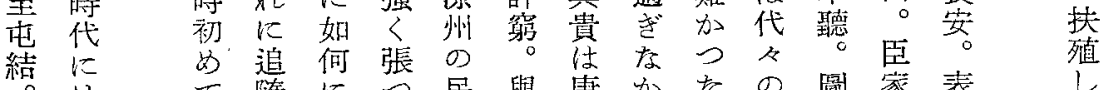

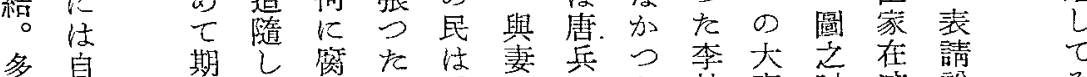

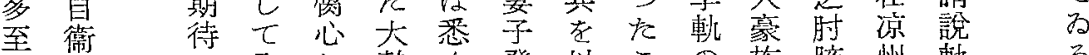

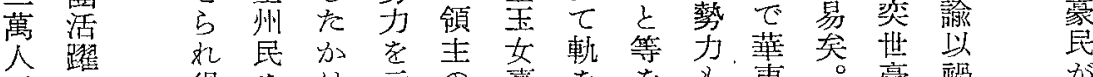
$\circ 0$ 少例 者住 萬 極 今

各多 煘战 疽 拒 治 賳通

鑑

僬

磨

至

德生現形立任票

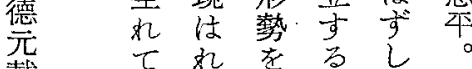

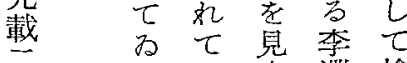

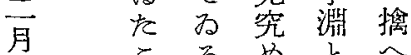

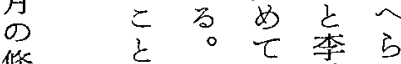

保

k

等鄉各䖝杂

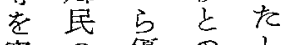

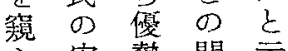

察安勢間云

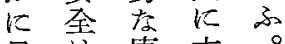

足住唐立 


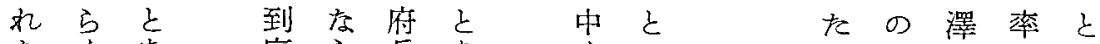

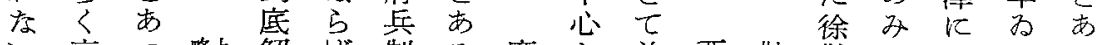

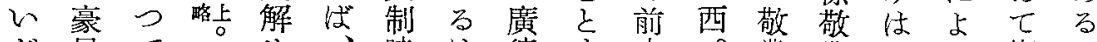

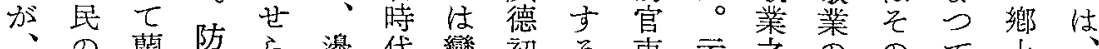

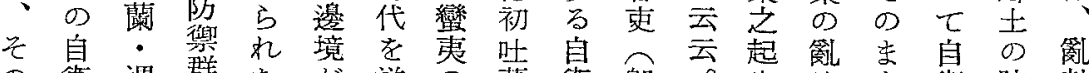

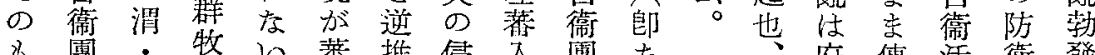

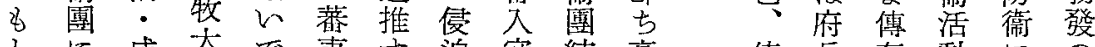

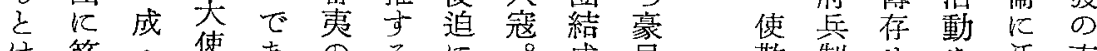

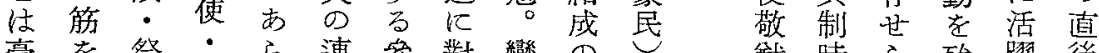

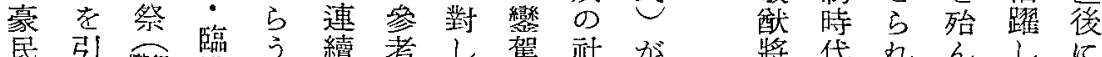

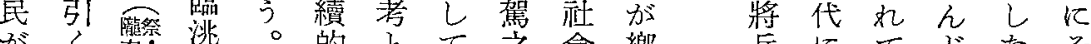

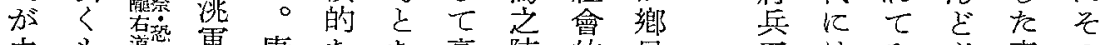

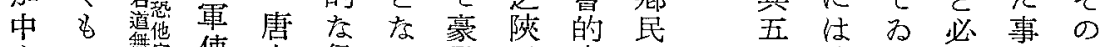

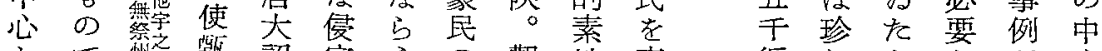

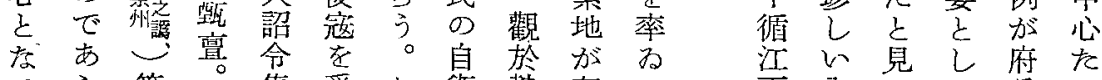

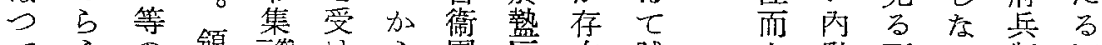

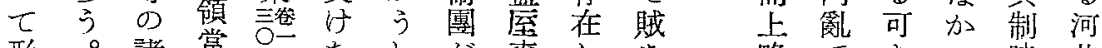

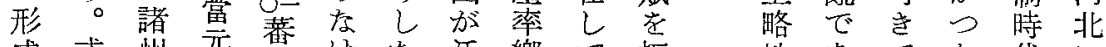
成或州元莫け邦活鄉て拒地あでた代に

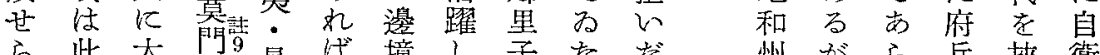

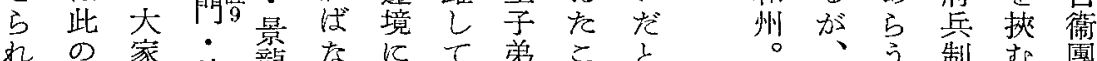
如 の 家 積 龍 な

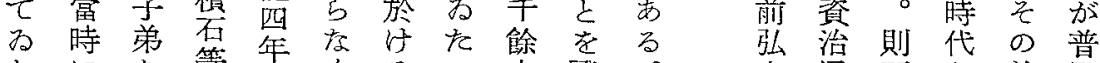

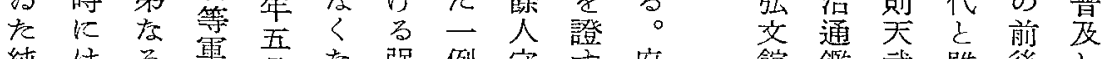
純はる 軍吾索强例守豆府 館鑑武雖後し

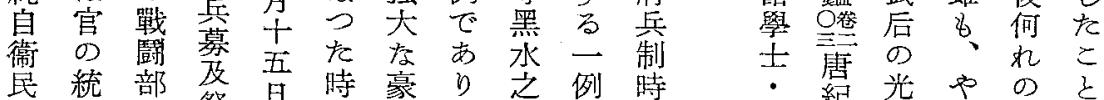

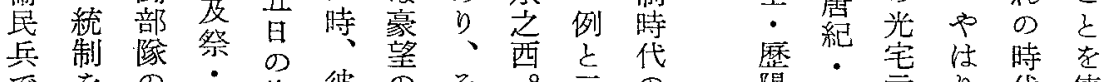

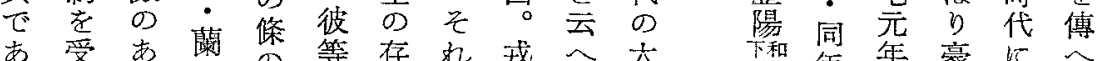

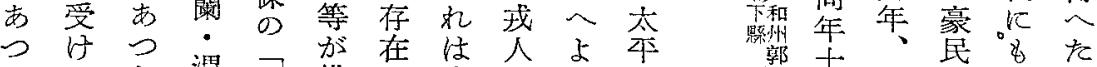

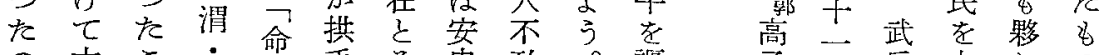

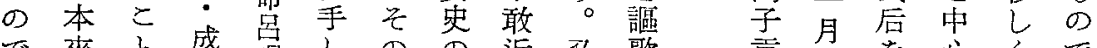
で來

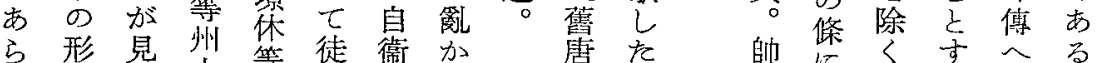

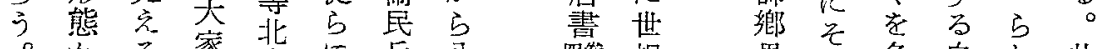
加る 家伐に兵八四泡相 里の名自れ此

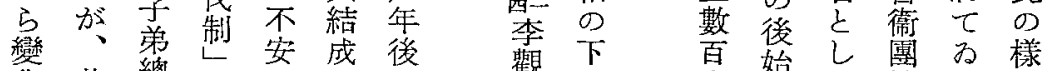

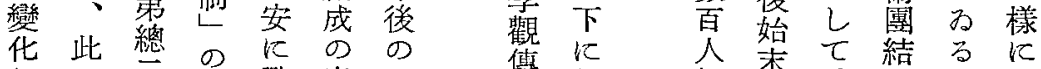

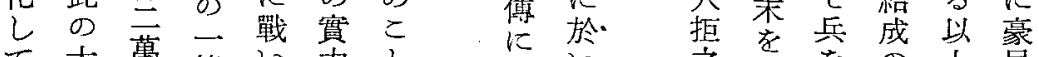

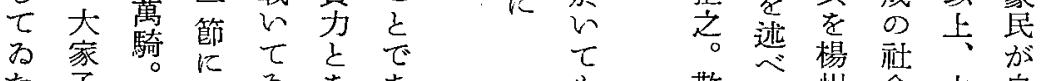
を子。なをあ が弟孛る 知恐立令が 8 敬 $九$ 州會太自 豪鄭飞的平衛 民不 擧素 の䚈 を能げ地惠を 
加家立はつそ干。

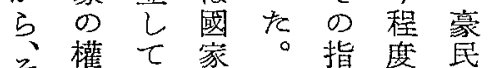

そ威るが唐導のを

統がる權梁者各中

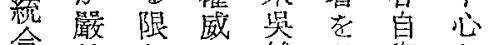

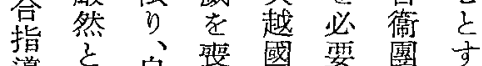

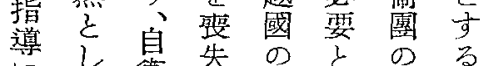

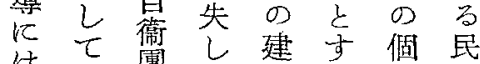

はる團艺國る别間

國た統。的自

家時統る索指防得

機代合場方菩衛團

閣にて合錢渚力は

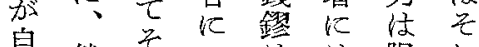

自然穴の度限れ

乘名指み前彼界 が

出佝揮㗝者等 が普

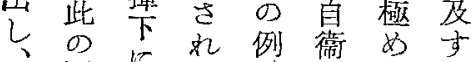

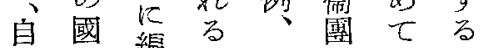

衙家編所易長低に

橉を全での中く連

名壓

亦迫方國國最士七

此专は家者適保聯

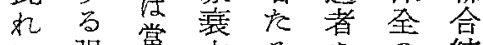

飞强賞亡る基学結

協大然期王推目成

同圭國の建戴的 の

产外家混注吉を方。

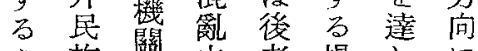

を族眮中者場しに

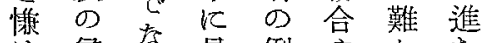

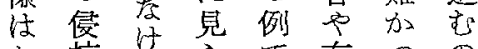

店掠方で有つの

加飞机市力たが

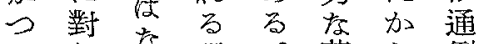

在儿索現。英方例

筈て 方像然雄でで

营結访でしをああ

あ成唐古分迎当。

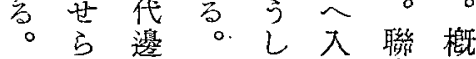

然れ境國をれ合奴

多たの芜指る。數

菭\&自心導場場百

此の雟權者合合乃

ので團威の等 至

統あは撨が當二

合る國確戴西然二
し衛討澚を有のた

そ團伐冦临度發。唐 の普に掠め世展大初 萠芨當は、つは宗の 芽のつ殆行口年. 優

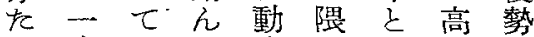

る史所占年な共宗な 役料謂年徑<時對 割を大中 $の$ 電著代外 を解家行大鍀乙の關 （2）果京子事き 乙可弟化在網、敵は 城をき軍し騎を唐必吐 傍名でがて馬張は隇菜 のの㐫蘭行民り强のの

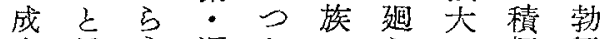
立思引溜たの索極與 は。: 侵重軍的安 れか成々掠乙鎮邊突 るう・如はをを防閊 。し祭はさ逐は心 左䓨引事次高復 豪? 然し坥要宗 興 民已淁た在地的 中 等 境問 不飞榎上 心 0 州隚可增年つ の諸民を能置頃て 純州の縫でしょ遙

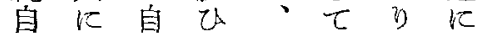
衛方衞虚軍此高惡 民た活を事れ畄化 兵つ動衝的飞想し のてをい要對潞 普動促厄地抗の契 及員し繰へし消开 こ苩返のを極が そ 5 衛 $人$ 重 が的跳

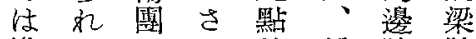
準てをれ的長防咙 官わ普、配大へ屈 兵る及高置なとす 的の地宗に境移る 民は乙の制界行に 兵邊め晚限線乙及 た境た年せ占た兄 る諸筈以ざ代。で 團州灾來る相彼一 結们市、當等層 兵於る彼得の遊重 下等な縱牧大 先る昍の分深勢化 行自萃侵つを另し 


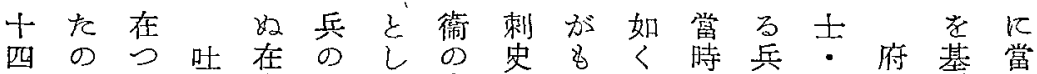
初載でた 萫 鄉侵て 責のつつで州が防兵礎つ

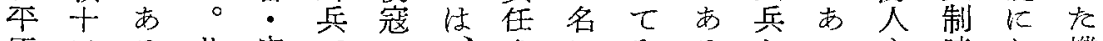

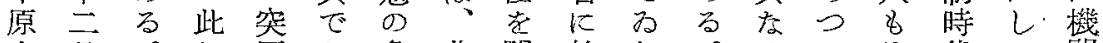

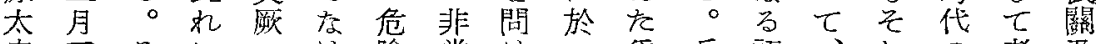

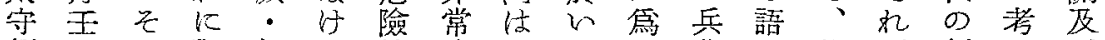

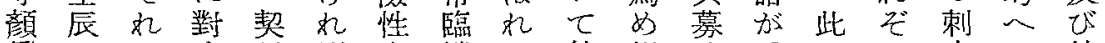

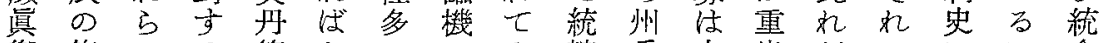

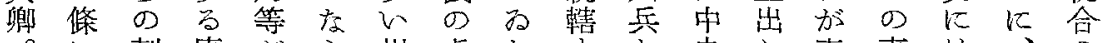
知に刺鹰方

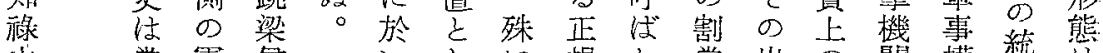

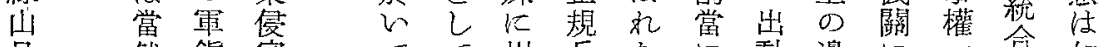

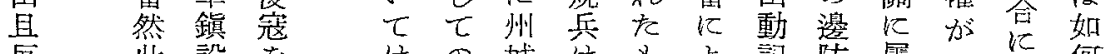

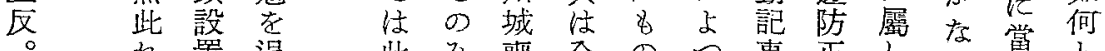

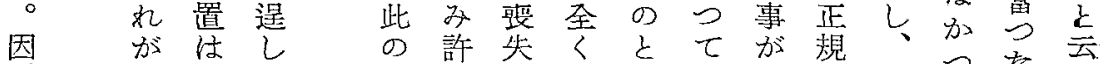

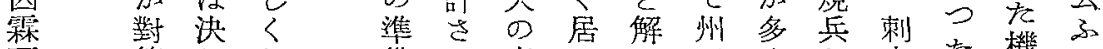

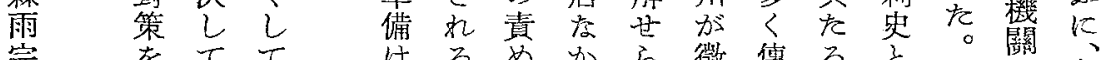
完 城 怀

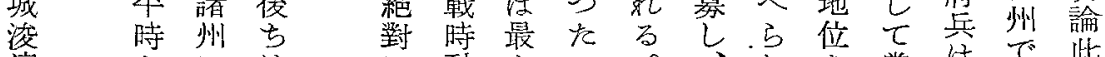

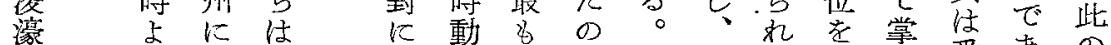

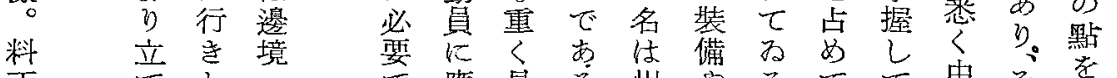

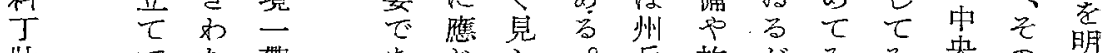

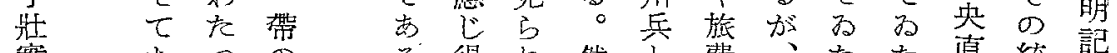

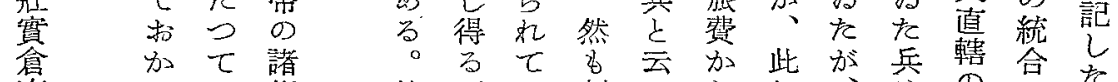
虔底わ州 けた柱 云 如 क 何 ばけ時 なで它 らなの 索く銃

加、鋒

$P$ 密 范

た方受

筫加方

治れ か

通て 制

鑑み ら

䉥存好

庥 州安

紀が京

- 多 狀

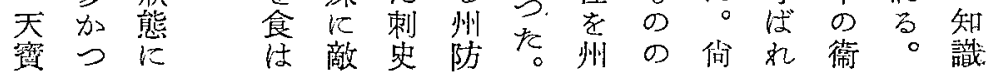
。当古云少此 が兵 然丁わ刺方 $ら$ 犯、在 然壯老史名留壮何全國最史 軍老の住、先的然電初料

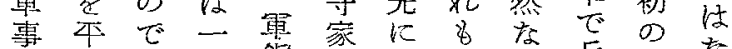

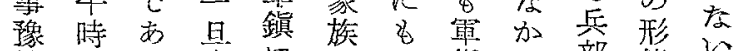

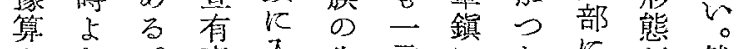

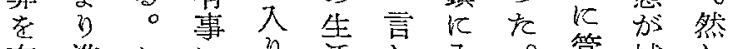
有準办にり活し入管城し た備引祭刺凟た可府轄倿此

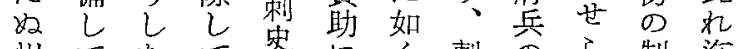

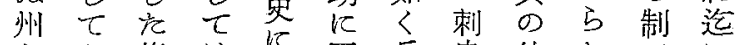

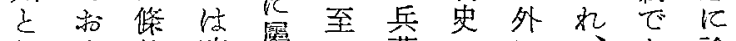

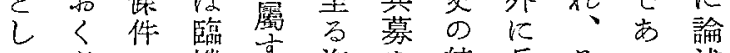

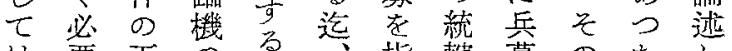
は要下 0 兵、指轄募のたし

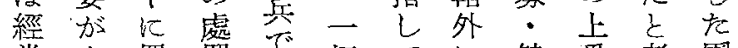
常あ置置で切てに健番考團

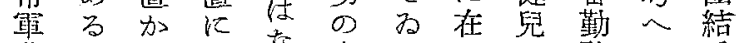

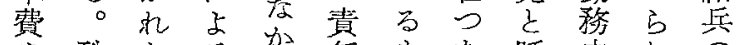

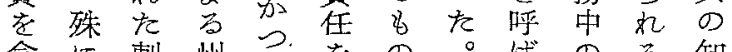


想て 刺はしう當二普を收あっあかてと

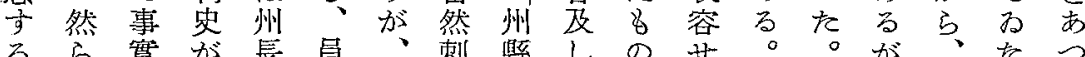

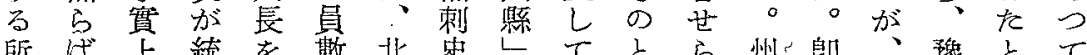

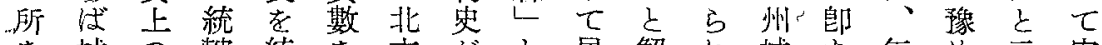
を城の轄 統を方がと居解れ城方每め云安

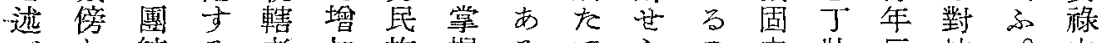
ベ亡結る者加族握るでら守壯 反抗。山

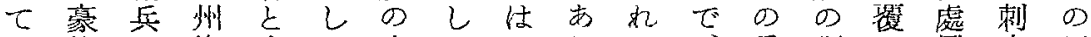

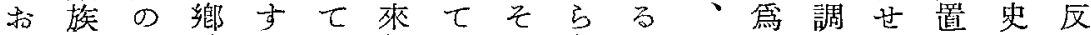

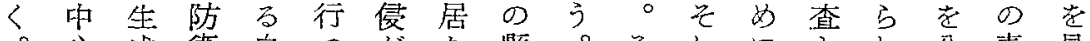

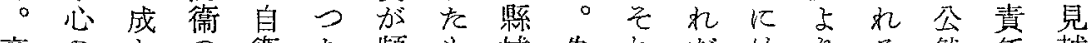
豪の

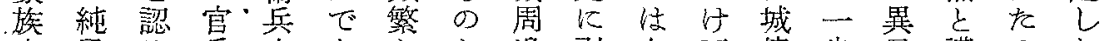

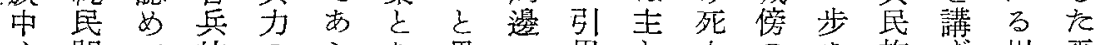

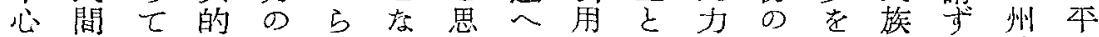
の自差民統引りはのししを丁進の方城原

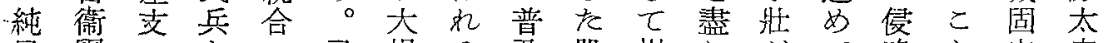

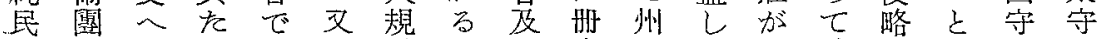

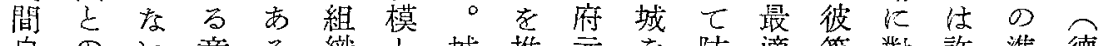
自のい意 る 織 と 城推 元を防 適等 對許沎 德

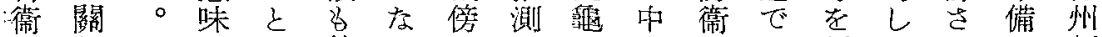

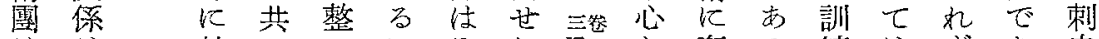

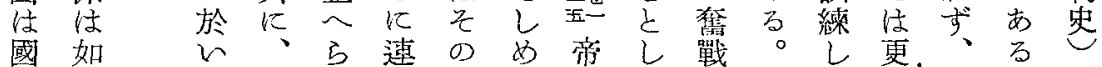

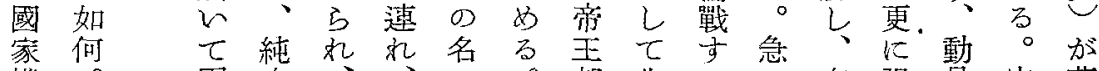

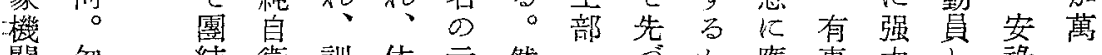

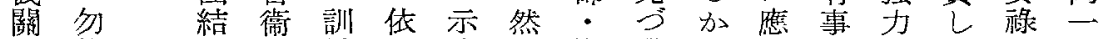

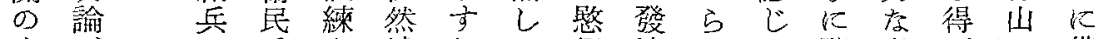

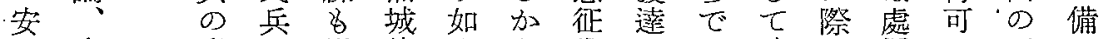

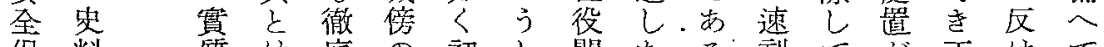

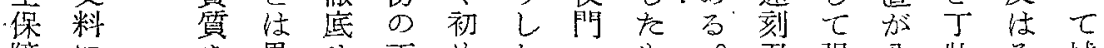

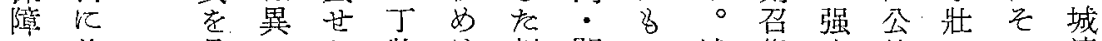

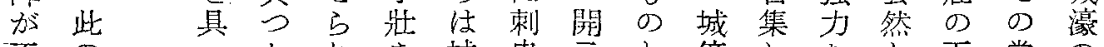
不 へた学城史元々傍し存と下當の

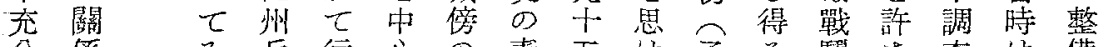

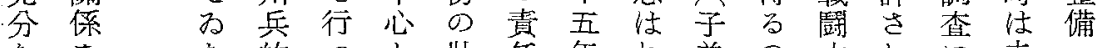

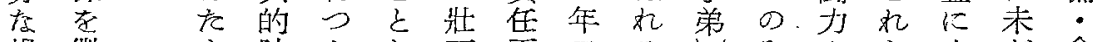

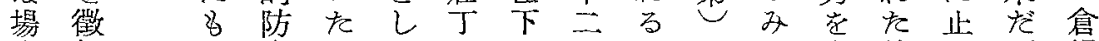

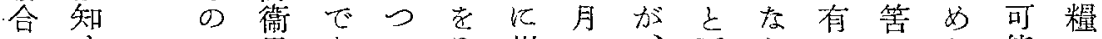

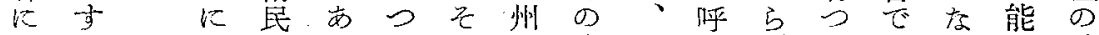

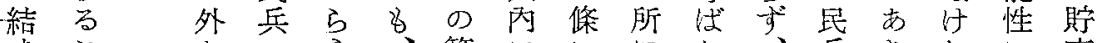

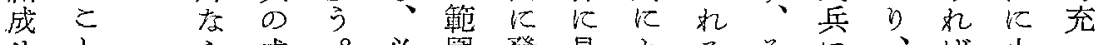

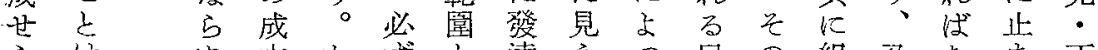

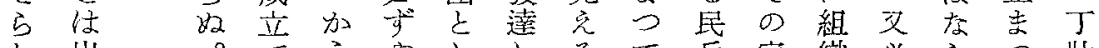

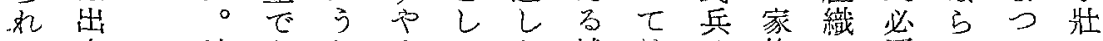

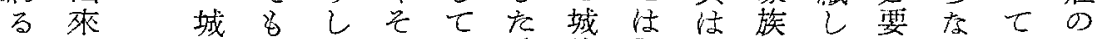

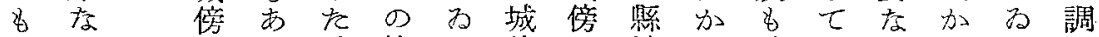

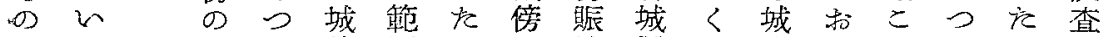

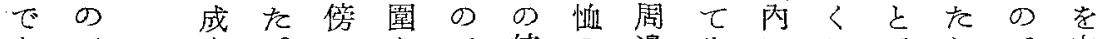
あで 立。

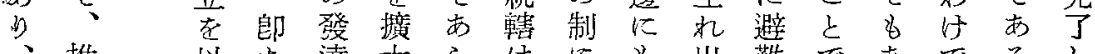




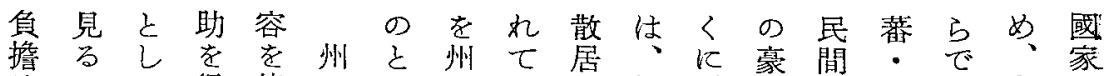
はのて 行傳の云のなし極從族自契あ豪も 殆 が斷ふへ統へ統る、邊し中衞冊る族亦

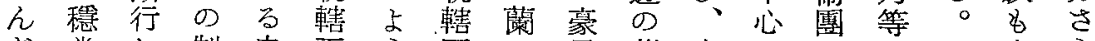
ぞ當し制史下う卡包菜豪のでのこ亦う

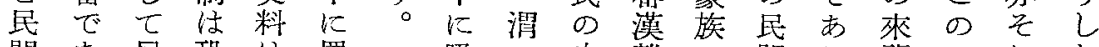

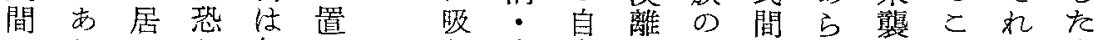

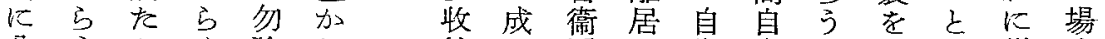
分引务人論机統。團の衞衞。受は從合

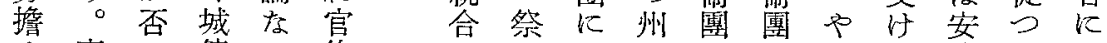
世豪分傍公僚 乙族疑 時、的 的問代只㣂 $\tau$ 自でに秋營 わ䒯 出出集を た團る來春受 のは。て散け が一寧わをを 最切 5 知城 初㤎城 \& の民傍ののは 行間のでみそ き自負あでの 方身据ら あ發 でのにうる展 あ角對。热等

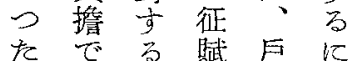
をあ酬要を件 解 つ報除基れ 亦をは準て 可點 同應 $\varepsilon$ 制 寻加保召乙度 8 資中 $\tau$ \& の推助 $\infty$ 點 $L$ の 0 身兵 $\tau$ 樣 $y$ 法睢 ᄂ 8 に、 $飞$ 給、整 思之上與百要 はのつ质五 机統七果十行 る合民尼た 的 間 $几$ 十 䇢 意飞刺五で 義韩史 丁 を榢㤎のる 有 乙 城 如 が 城光傍异そ 傍た遇保の ○之法資內

し○よのははが初㼛ての

$\tau ?$ 了 如消次七め山兵み 威外く隇第强たのを此

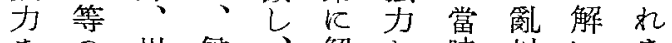
をの州侵、解店時以认を 强諸晸掠特體唐、後 $\tau$ 容 化州官の殊世米宋認

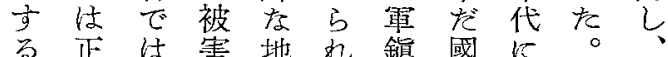
子 $下$ 到永域て が家至國又 共这底特に行置州方家は Kう安にのつ加府亂機時 、乙全甚みたれ文構に

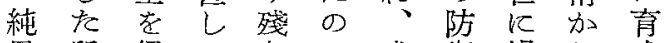
民所保认存で或衛繰 兵で障にずあは對返離を あし \& る 州る得拘に引傍㤎したる 兵。店 5 至。整見人が 的つ以す城充は受民 民ま椂、在傍貫疗仔の自 兵りな州のがせいら武ら 化結 地域で州ら間方装 し果で廣古縣れにるは全

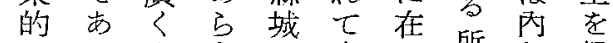
州にる人引安安所部保 を見。稀。周全てで秩障 介芥大穴特邊全先市序し 乙、家、殊加强亏゙ $\tau$ 城子州地 方化生。面る 國傍弟縣域次確れ上加に 家は治上第保出つ的“至 の民るをしにせをて好れ 統間者遠て鄉らの思ま快 制 の $の \zeta$ 考村れ㤎ふし此 下豪活離令にる豪飞くれ 飞民躍れる浸に族、志を 置的方元透從中突少解 心自傳漠れて去心劂つ體

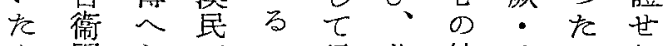
\& 團 $ら$ がの行此純吐かし 
のるのの兵新同時

の先國民で城な民代史

み天結 兵历傍問くに上

で二兵でつは題す 入に

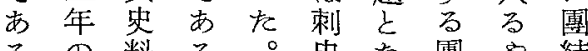

る。料る。史疗團や結

換 北る $る$ 典之一兵之

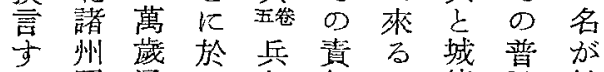

礼眭通い部任。傍及始

ば䋱天てにに勿と增見

州兵元は於論肪加索

政馬年城諸々同の省

的增 $の$ 傍 州て 此 時 實 の

見加山主城結の代際は

地等東變傍成區に老

加武名別丽反后

ら開騎無弟を索映の

刺元團加。州說相乙萬

史以設つ亦墽明並七歳

に前置た常防しん透通

上の品令衛たでに天

○初第、呚の史用多元

$\tau$ 期三不習民料ひく年

置國の的兵注ら店の

分結史はをで店就了武

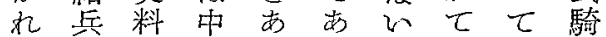

た史た央るり。るわ團

城料る の店、る る 設

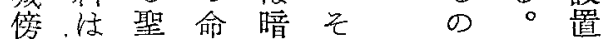

に嵊曆令にので然命

對々元 $k$ 此 統

亿中年基 $の$ 轄

、央 $\sigma 心 こ$ 權

畻㤎河 $\tau$ 之 8

結々南州を刺

兵 の・軍 示 史

度命河がしに

明を北結 て 在

加以武成子的

にて騎しるた

國諸團た。。所

家州設 8 霣 0

的に䈯 の 結、

見編第で兵い

地置第 あ 多

汃せ亦将

らし $匚$ た 州地

州め史。藏方

電在料始防 的

飞\&見衙民
あ 8 令

方市

此倸 る

に城爾

於 傍 後

以 o \&

$\tau$ 名 串

城 芯書

傍 見に

之学 散

㕑、見

結そし

乙實 開

斦 元

區內 •

别 容 天
る 두

がを 落
ば而でに實

（3）城 L古城城に豪

傍七る傍傍 諸 族

團上最芯がの 州的

結磨を 何設が自

兵結 後此時け方龦 $\infty$ 兵出 0 頃 53 鮞

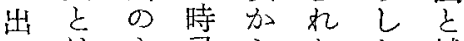
現は名已方をた城 發 $に$ 出所關傍 展は邊現を 係を 段開防しあをの 階 元上をつ辿關 的二の加た $っ$ 倸 に十量杜でたに 如五要 全あ 之對 何年要々 度素制引方苛 る る 閣亲發梞で上 係典展いは は をのし。应推 有記七私則

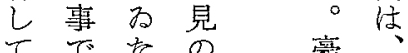

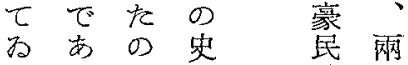
たるで科的者 で。㐫は自が あ此る僅衞其 ら の 分 か 團に 期 5 《 00 存 加間、發在 。起個生乞 次正原它证 に应場 此闻更更合 の結にの 州に 問兵ず最で就 題 $つ 8$ 然 江飛古古的 就囉溯い刺の 心的 $ら$ 史發 七發甘は の展 考展七 朔段 祭 時考方 到階 产代方方的 るで可面 思な あき るで景少 察 然る 西龍 盅 ら。年先現 


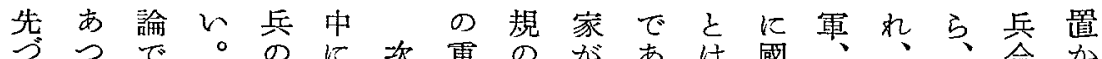

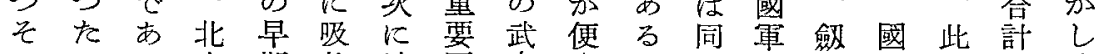
ののる。方期收城要官宜。じ的南軍の十女

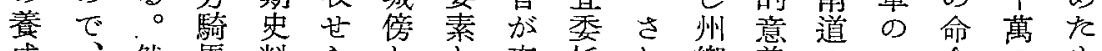

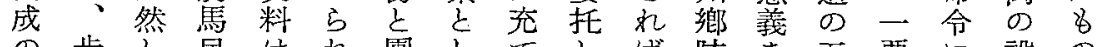
の步し民は礼團してしば防を五要江設の

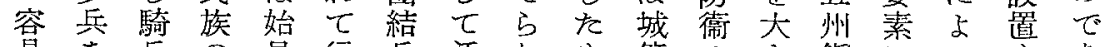

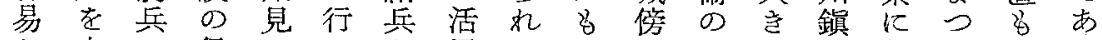
な大侵のつを角てのは民く防加て亦る

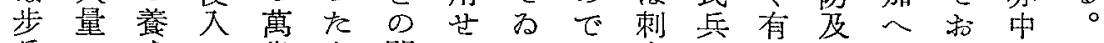

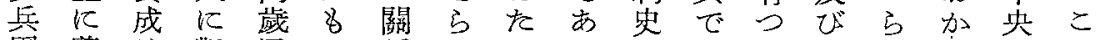

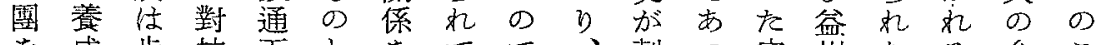
を成步抗天ををで、刺つ官州たる命こ 設し兵言元解發る あ從史た兵橉官團に上 置てのる年せ展たるつと的結兵結よ住

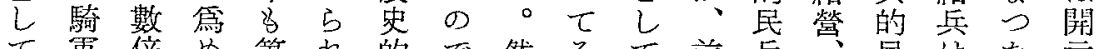

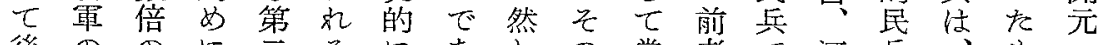
後の の に 与不經はの。考るか統然は、南でたの天 武足費騎聖此察汃引轄的州明道あるで䁲

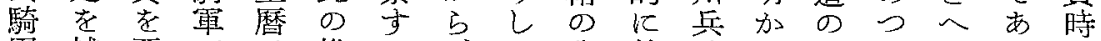
團補要が元推る、資統的に登た州る代 につし必年測にそ區格轄民中之立军。に

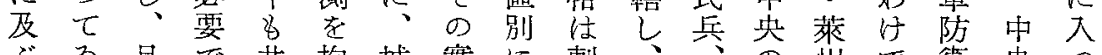
ぶる 且で共抱城實に刺、徫先つ

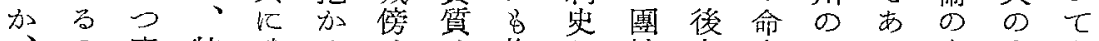

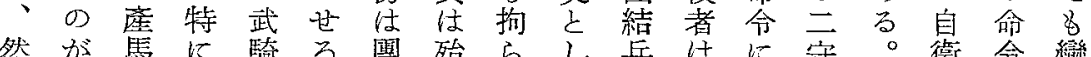
然加馬に騎号團殆

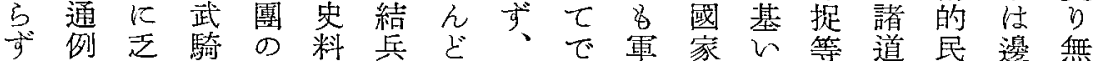
とでし围設はの 園景な鎮的ての兵防い すあいの置團母結龍く外民編如軍での。 るる中設記結胎兵四團の兵成く鉸支大河 8 國置事兵を年練的市世獨につ局西 同加でをでに去變の使のる方自編た的・

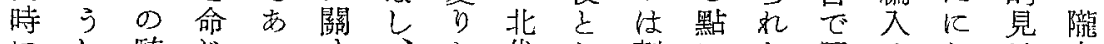

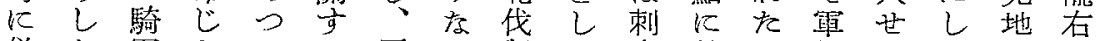

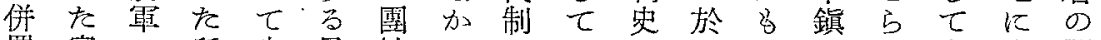

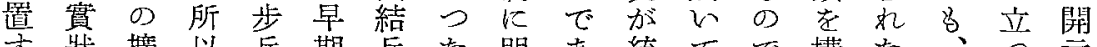

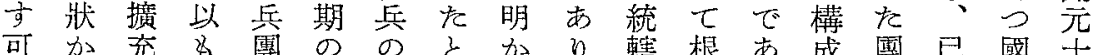

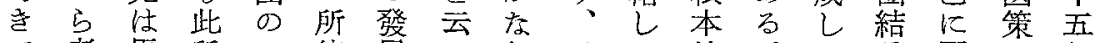
で诺臨所こ傅展へ如又て 的。兵國に年

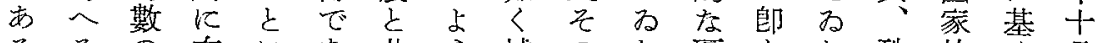
るるの在にあ共う城のた區与た殊的く用

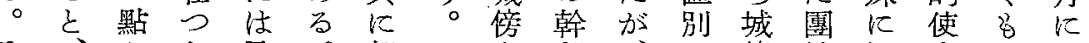
そ、汃友却部、傍結河命の於

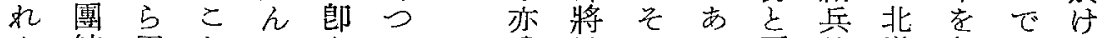
を結困とでちて邀校れつ国等道負ある

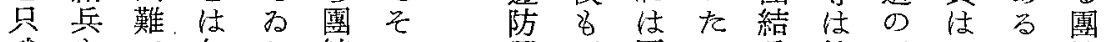
武当で茐存結の 電正國の兵特五さ方結 
史で傳に當難し成兵度國て方たた騎こ騎

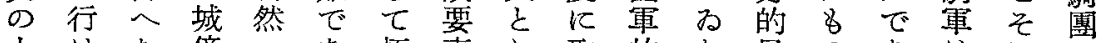

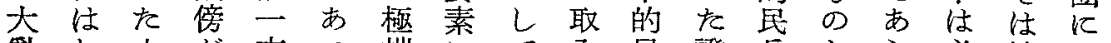
销六六方つ端にて 入民證兵とら必城の

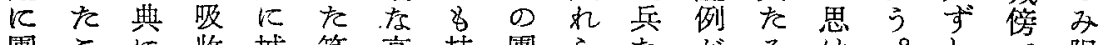
團こに收城筈高持團らた战るは。で限

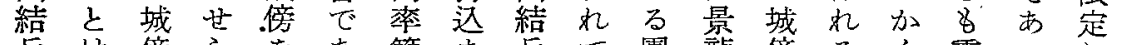
兵は傍らをあ簡ま兵て 團龍傍るく重つし

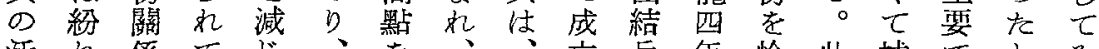
活㞦係てじ、を立兵年恰此城でをる

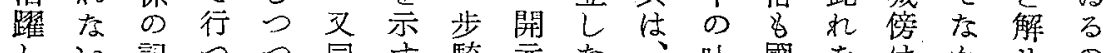

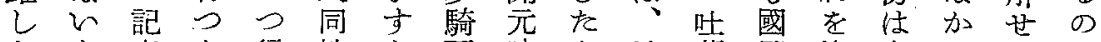

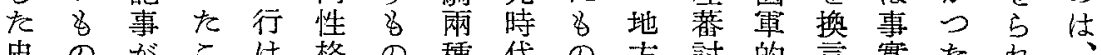

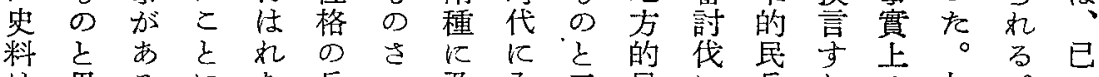
思るにた兵へ及入云民兵的少加。に

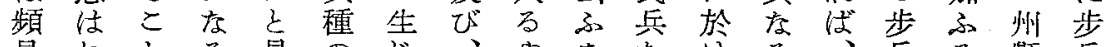

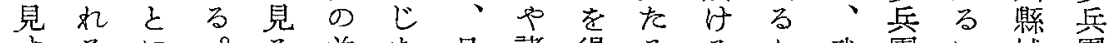

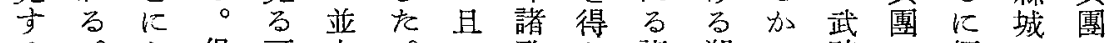
る。よ但可立。る 政よ諸朔の騎で經の が が六つしき的高そ刷う州方如䁏あ費防事

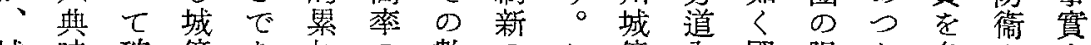
城 時確傍 あ 加の 數の加傍㐫國限た多を步 傍代め驾る は步 8 玄く城家定第々第存 活上 5 長。不騎激宗七國傍㤎的め要一在

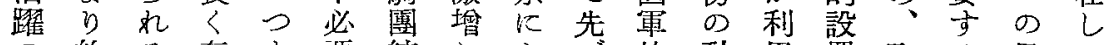
の約る存ま要結 $し$ 吉的動用置取る 目七

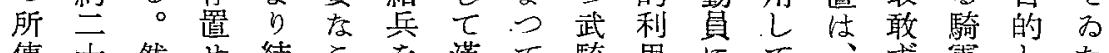

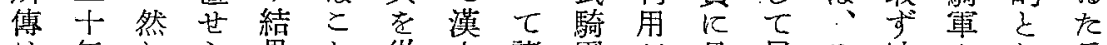
は年しら果と從人諸團孞見居と缺をし零

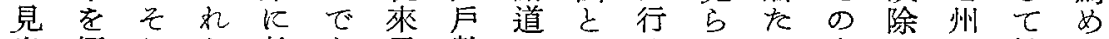

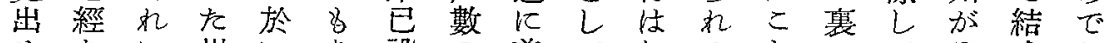

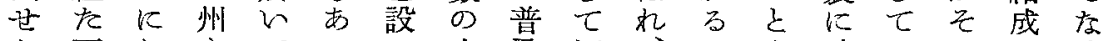

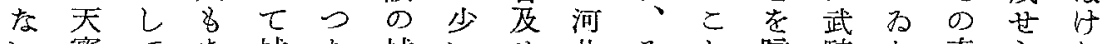

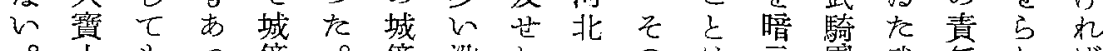

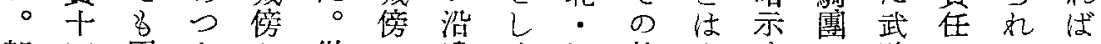

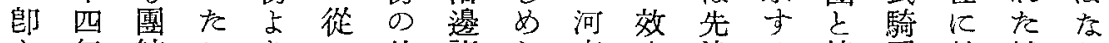
方年結こりつ外諸 $ら$ 南力述る協團於城

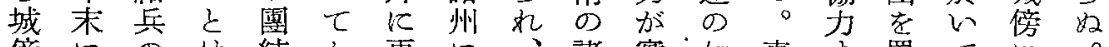
傍に

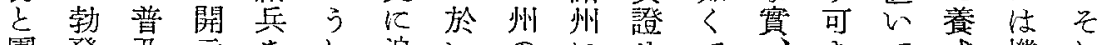
團 發 及

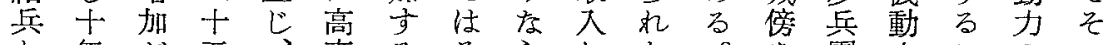

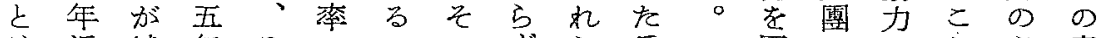

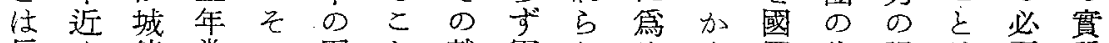

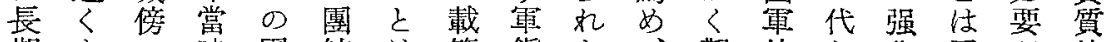

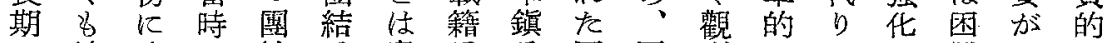

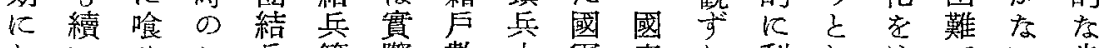
わいひこ兵簡 蔡數力軍家れ利しはでい步 たた込との點上にの的的ば用てかかか兵

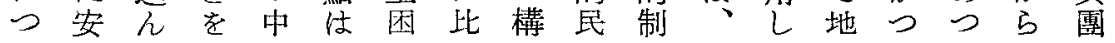




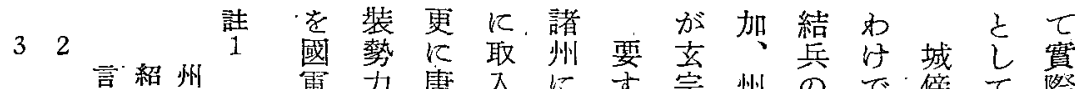
罒註し介・央電力唐入にす宗州ので傍て 際 の(1)て世天洲のを 朝犯於る郎市推あはのに

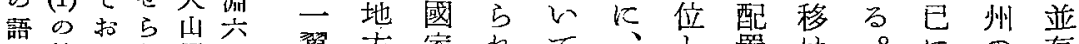

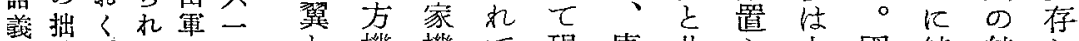

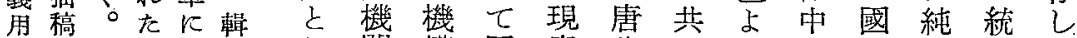

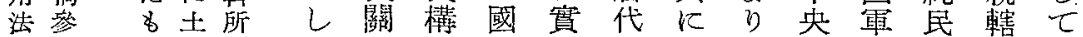

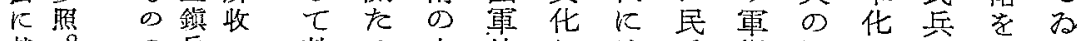

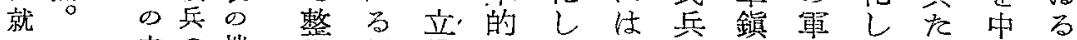

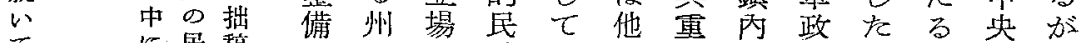

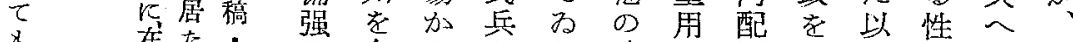

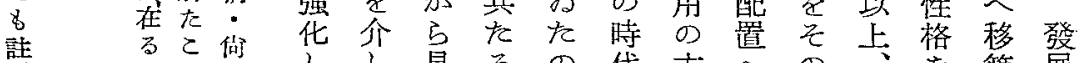

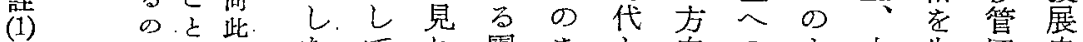

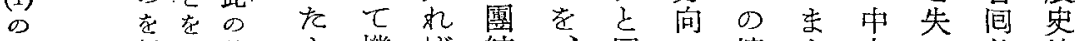

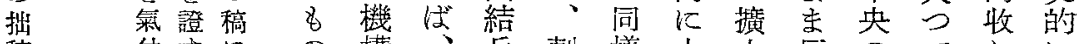

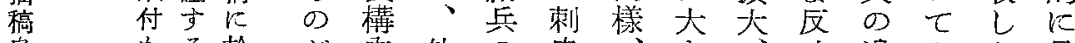

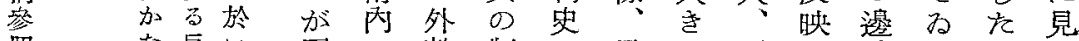

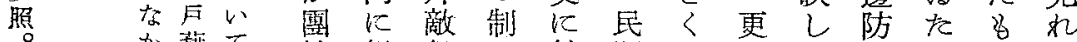
か藉て 結 絽侵を統間進にて政がの代

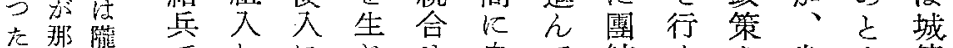

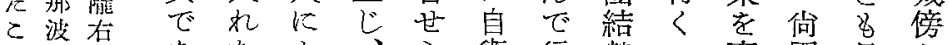
之博道あたる、ら衛行營こ直國見よ

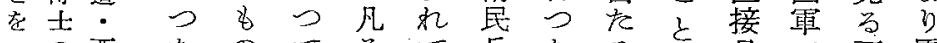
一の西たのてをて兵たるるる 且で可国

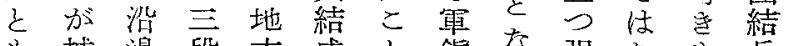

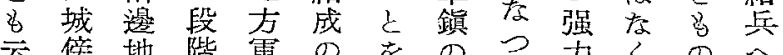

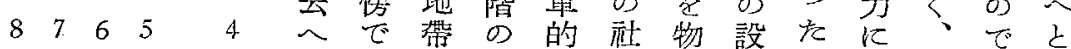

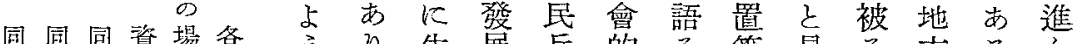

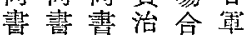

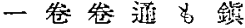
九一一鑑今 $\omega$

○八公卷後舆 九公一の激 公詳沿 七考茈 儿党 俟 邆 t 一 权究 ば明 な 斿 53 婂 2 $\varepsilon$

引口生展兵的る等見る方るん

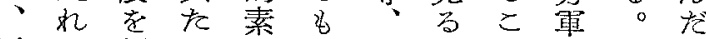

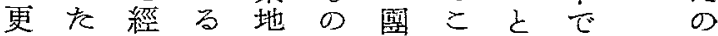
に壕て 城がと結と市市 此民わ傍遍云兵方なる

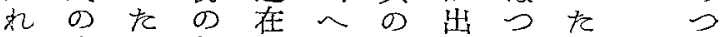
を自名制々

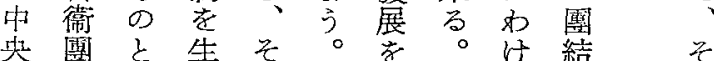

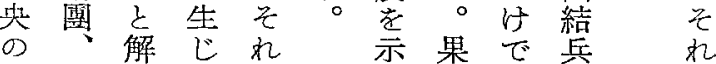

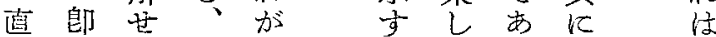

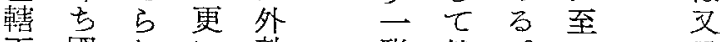
下 國我聯然。敵全居 に家る 此 $\sigma \quad \omega$ 此 $\tau$ 兵 四の の 收統で城䞚政、葍ををめ對

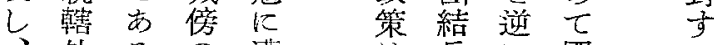
外る $る$ 漕仕兵飞國方 且に。制 尔の云审地 立此をた学些化方

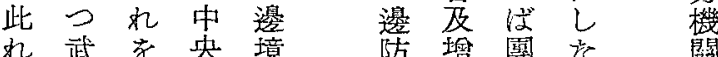




$$
\text { あに五と、云、の期よ原時 }
$$

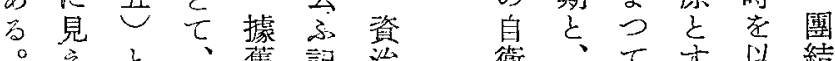

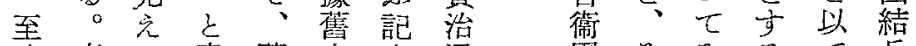

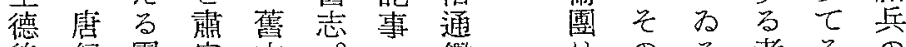

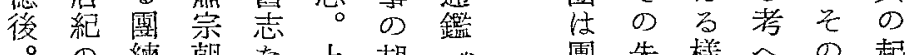

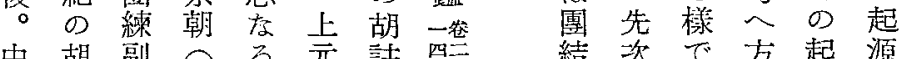

中胡副 $る$ る 元註四結次で方起源

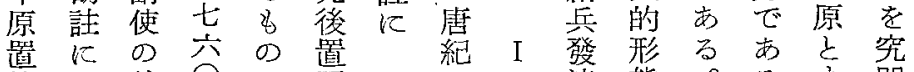

篩云註: $\bigcirc$ 国

度交文! 據練

使舊し六り使

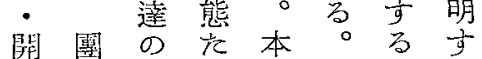

元結素る稿中考る

文度之團

郡抵 2 涉使

晸舊衤前後

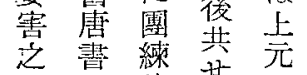

地

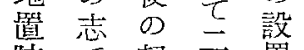

防无起司置

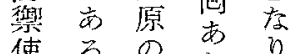

使亏 の

治そ元兄言

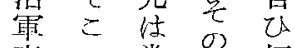

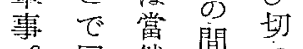

。同然間

副畫開約て

箫職西公公

忘官前前主。

不志篎年 庥

賜防高㫜に

旗徭宗開は

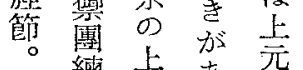

上練志充充

元使元尚年

後項变開 號

改見应元高

二兵地 地で國 $へ$ に

千兵方

七即之電此のだつ

年置 乙 的 の云あて

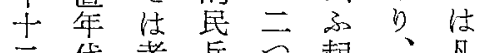

月代考 兵 号起、 凡

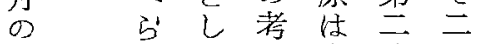

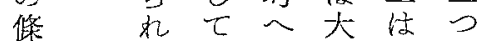

のるの方體完の

が城を 前備 場

劍、㜔共者し合

南起のにのた㤎

節 原出取栐、圖拷

度现入現入結

使問時犯考兵

張題期、へのれ

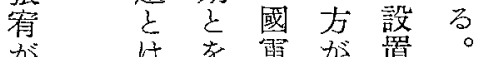

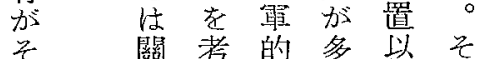

笔究民永前

军市兵がに第

政少当、溯一

字 のこし今りは

團てとて日名

練言と名一の筫

副及字筫般萠共

使 乙名共に芽に

意瓜长云形完

仇 官完ふ態備

䌽 $\circ$ 兵成起 0

椱的し原出を

に 性た现. 現團

委格 国 後し 結

任を結者た兵

乙 有 兵 $の$ 時 が

焦鹿年 六

練罚市西

守等无!

$\tau$

子

たの教を置

た

c

始

豪設方 $\tau$ 如 民時に起を 


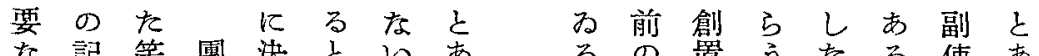

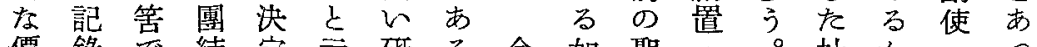

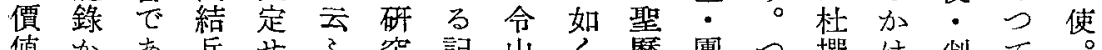
值少兵世京究記山く厤團つ撰は制て

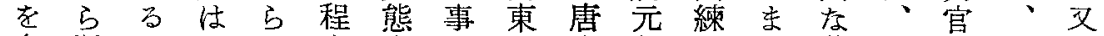
有漏かとる度度と近會年使り舊開が安與

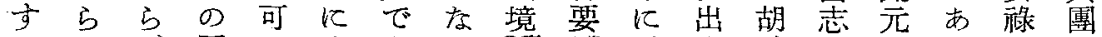
るさ、國き止ある。望忞已現註に云つ山練

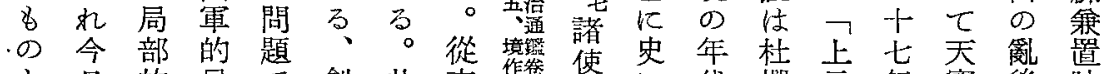

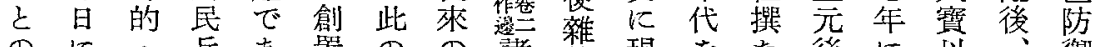

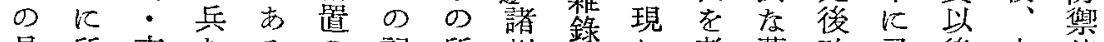

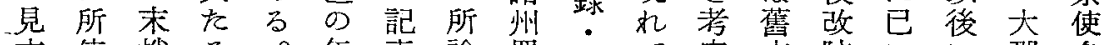
方傳梢る。年事論置萬究志防に郡名 が索的 の そ 問性 應し 迭題格

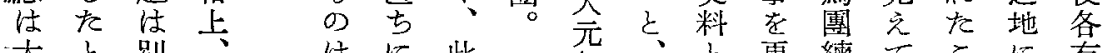
大と别、代此年、を更練てこに有

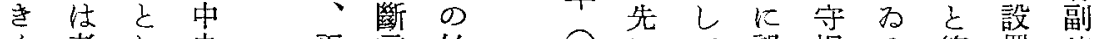

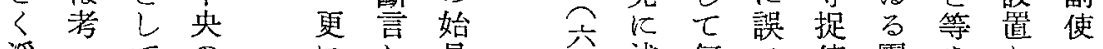

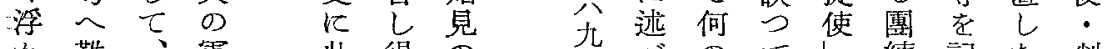
難、電此得 びく唐事れる年 上、代政占こ文 与從軍策方女以 $\tau \supset$ 政 $に$

來て 史直草往只直 。歳の謷 溯々に 然通劃 り ら 0 團 己天期を せ 由 結 絕元的有它來兵 對年事吉教学 にの件、少置 所始店必得 $<$ 少 傳見るずると年 漏史乞中加安症 れ料 0 央否萬り がを 創の か⿰ 歳と 無 創置方 $の$ 通 斷 分置驾針 考炅定 年 輕に 祭 元 在代々基省年 とをしい別迄は 注く㻌確方 断究报動貝法 言严依加に的 出るれさ溯に 來上 $\tau$ れ $\zeta$ 容 なに中て後せ芑 致重央方得如

六心゙のてし練記た物 公價解と副し防官 九如值㘁 あ 使て 徛

月く8 をるをる 使皆 のて有しに年るるを学 條あたた據寶。上珼 にるな子每職元後

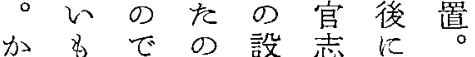
くのあが置の 雷 $\tau$ で 胡 露を、註しの守 結る然のて記捉 兵。名口わ事使 の團々據るがに 始練 の舀一如 改 見使上志事何內 史は元。ににを

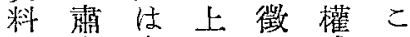
從 宗 需元し 後し 威と 來上. 朝㯰明应防 已元 の 團少い罡 にを上練で出使 指 溯元使市 觶 摘るでடる目團 せ六、の齐疗練 ら十團句、名使 れ狳結でさのに て年兵あうでは 


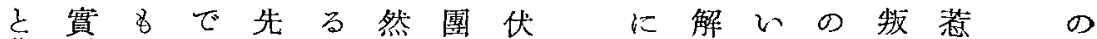

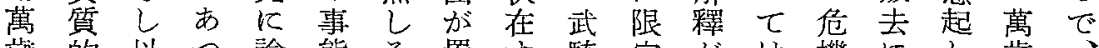

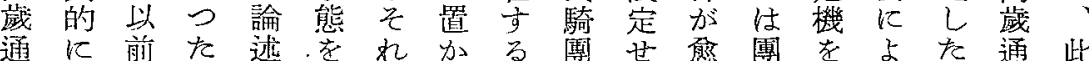

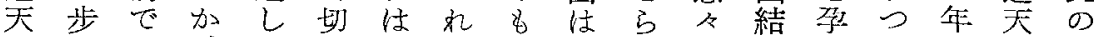

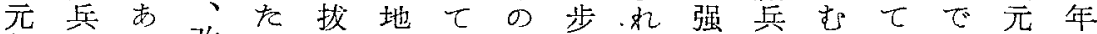

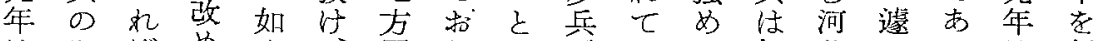

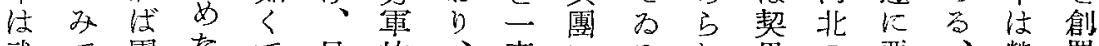

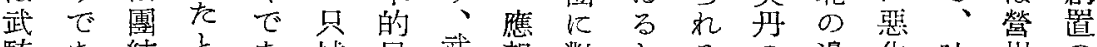

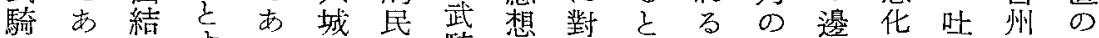

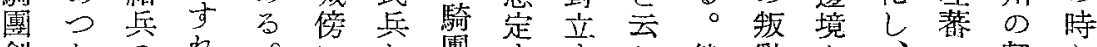

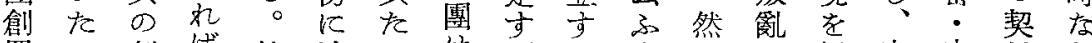

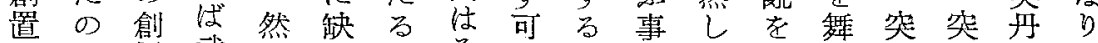
ので置 武しけ城々 き

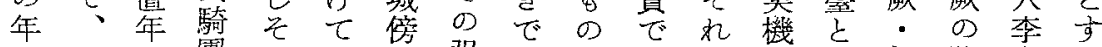

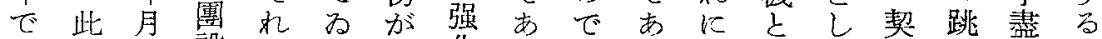

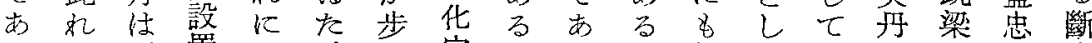
るを更置し騎宣完。る。拘て 始のに等，定

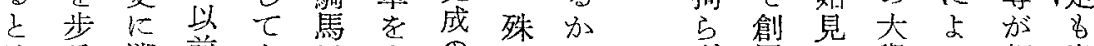

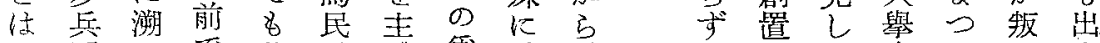

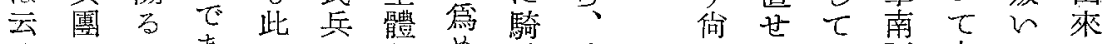

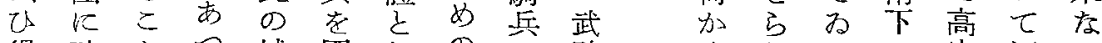

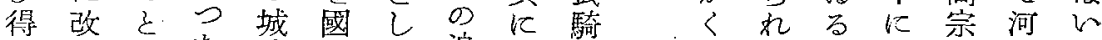

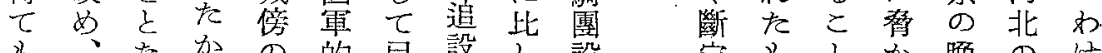

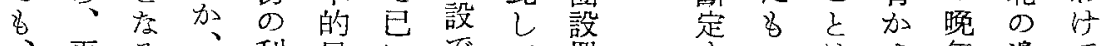
国更当々利民にでて 犆 結 $k$ 加用兵發は轰

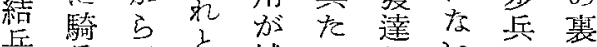

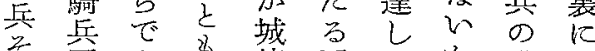

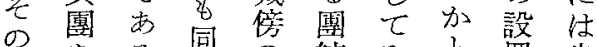
๖をる同の結わ䈯步

も追。時ま兵た の幛兵

の設つ度交命考流團

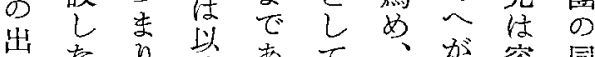

現たり後あて的答同

のの城栠つ追そ抱易時

年か傍あ゙た設れ市で侻

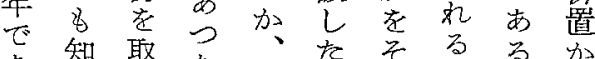

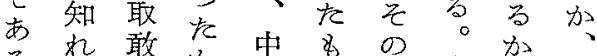

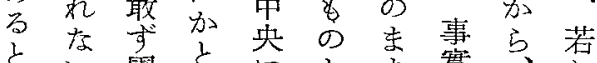

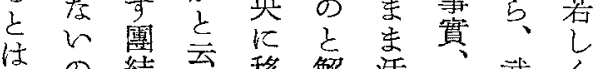

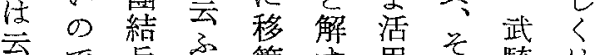

云で兵尔管市用如㚡は

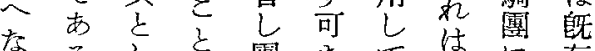

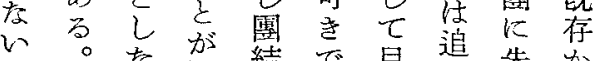

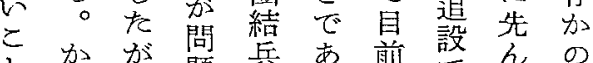
之かが䟎兵あ 前設ん゙た

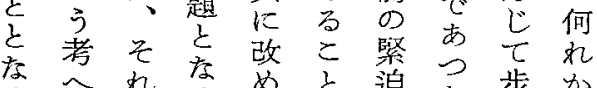
る。机る る

すのは年櫋で

るで、れ以境市 に少る來をる

は萬れこ辛冦

一歳が 々 $心$ 掠

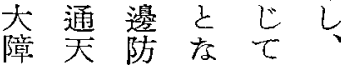
䅞 元のつ邊々 が年新た防 の 存の桀。を 餘 在始危新支黨 主機孛への る史 人兵つ蟲 ○料 の 制つ動 そは對た あを 如師策 万つ加 はちちで團たへ 此 創 あ 結 唐 の置つ兵 の 敬 始史たの態年 見料こ史勢に 史なと料はわ 料らをが此を がん示此のる 武とし。契 大 騎す、年丹麀 團る姃そ心を 


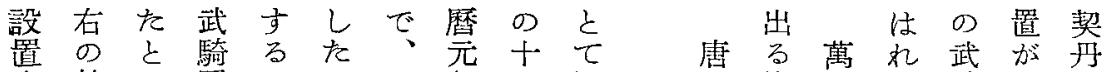
萮幹云團ののそ年一河河會迄歲る騎武の 合部ふのはでの臘月北南要に通。㯖騎版

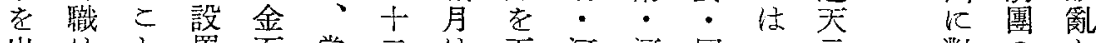
出は 乙そで命粹時月實月南北卷年年應設云

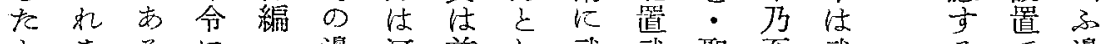
子 卞押。先五情北年、騎騎曆至騎步市防

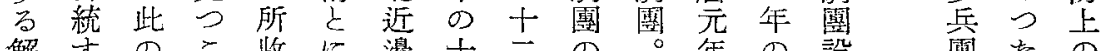
解与 のこ收に邊十二の。年の設國たの

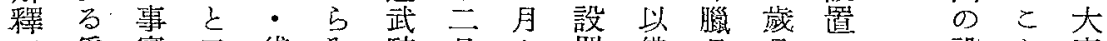

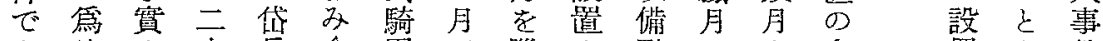
あめをさ岳 合國で臘を默示を命置を件

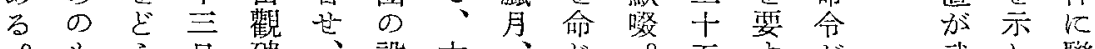

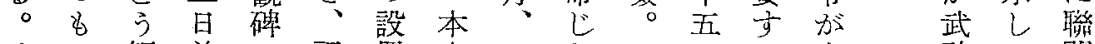
然の解前の更置來々た云日方出騎七關

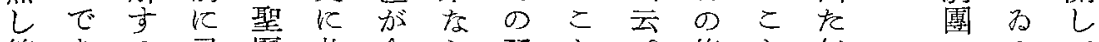

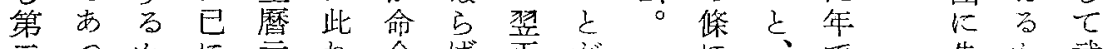

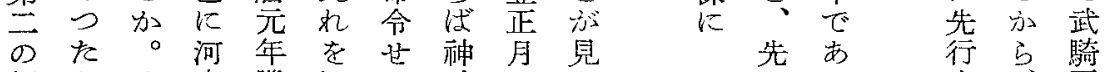
解々先南臘河方功を文

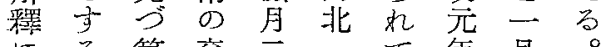

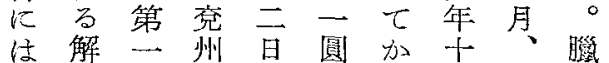

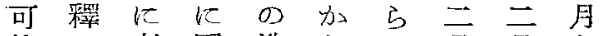
能で考團造ら有不 性㐫分練像河年々焦

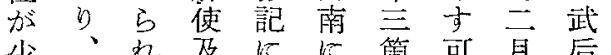
少、机瓜筬可月后

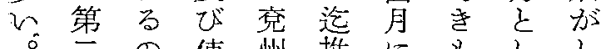

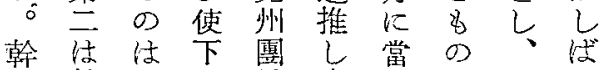

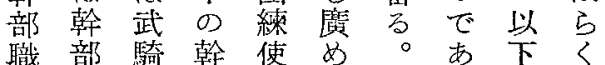
の 職 團部押を恐る此制 任を設職牙の方。定 命任置が・でく桐にし 壮命命任同市河功順乙 纪 $L$ 令 命都 方北 元つ に手の论磨引近年たた 設筈前 置をに晶の所の萬の二 の 整已活職で武藏で笝 一几に躍名此騎通あ月 部て步をが所團天る制 行分兵開見飞設元。度

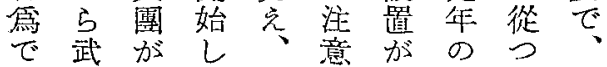
两騎居七河を實翌乙通 る雪て 南要現年聖常

にる

他。

地 既

區

K 述

於 倍

it

如

後々

の

例 3

加 L

占

考 命

說 令

し が

た實

如

<結

でん

あで

る 現

實

團

兵

公

生

れ
行守、騎

万武

分 騎 名

否團 が

かは始

《此見

๖ の -

つ時 る

て $の こ$

團 創

結置

制あ此

の $\supset$

創た大

始上事

年皃件

代 $\tau$ に

が琶 遭

突 5 湑

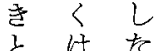

め大磨

万過 の

机市英

万る 斷

\& ま 的

の心な

子。新

想此措 
天しれりに溯河軍にに傳部結ては前の

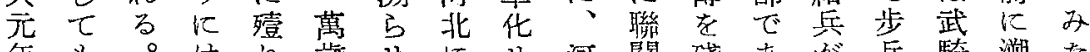

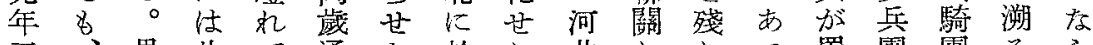
五、果此七通瓜於し北してつ置團團るら

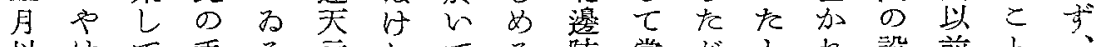

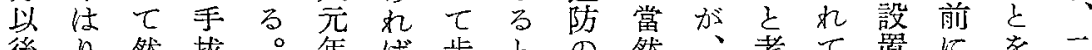

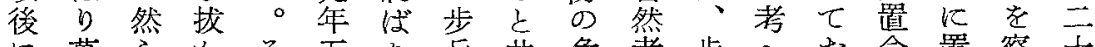

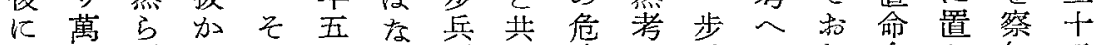

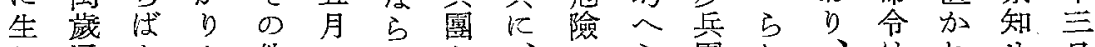

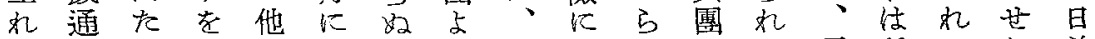

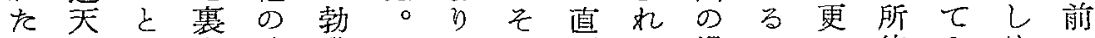
\&元へ書邊發生の面る場にK傳るめ心 の年 步 裳 境 L で五兵市諸 た 月疄了州契 此以名民手 の 後武の 中 $の$ 年で騎が央 叛

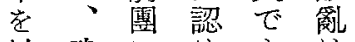
以武に少\& 8 て 騎 先 ら此 そ 團團々れ执の 結にじるを直 兵先七。豫接 制 行 置 諸見 の のす分對 し 監 出るれ策七督 現こて在對官 乙上み主策 た四たべをる 年䇫 0 講營 々月で亂し州 見以はのて都 て下存起わ督 殆でいつたを んあかて者へ ぞると後は事 譟。の 5 無 前 從推遽妿に 無つ想加つ察 认て㤎にた自 \& 團 そ取で 立 の結の上市 之兵まげら能

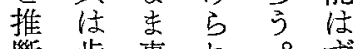
斷步事れ。竞

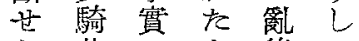
共で\& 後て 礼市ののた 当萬つを狼の 。歳た想狽禺 通々在振䟾

誕缺し面合名此漏衣、碑 乙除た兵应拘 せ 唐團殆 5 年 2 兵部は 次る朝\&んずは橉の已 い武は確に゙、隴つの任に で騎取に殘そ存て 幹命彼 萬團敢括さの・わ部と等 蔵をすか应設關るな武幹

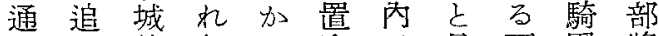
天設傍乍つ命三見可團將 元しを索命道なし設校

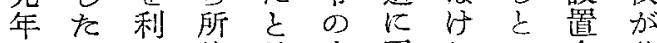
九の用傅見史團れ命此 月ですをざ料結ば推令の のはる殘るは兵店测々時 武古とさを見制らがの相 騎る共存得出肪奴生時當 團まに方存甘取。間の

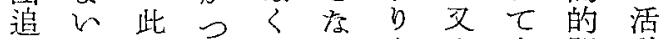

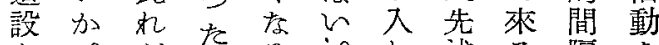
を。がをる。礼述る陵を

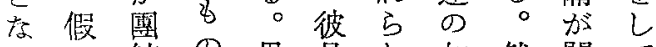
长結 の果是就如然開七 をさ兵とし合、くしきわ こう人のて沙步主た そでの推”然考州噇兵ぎこ をあ 切測 $ら$ 人。右團七 なつ換がばる設道設るを

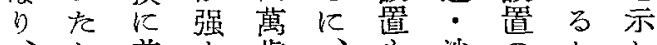

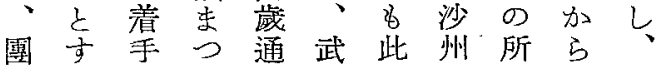
結机して炅騎のに傳でそ 兵代、來元團三は史あの 制、步る年の道開料る任 出團兵。の設沿元は。命 現結 團因武置邊三なが の兵々つ騎 は普年 年在して團上置加。龙

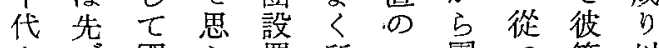
を國灾置所一團了等以 
河年上の會三在見見道皇せて鬼城 東月ので州年河し順年行城突ばわ集傍 を大性で西て次次電傍き少る史の

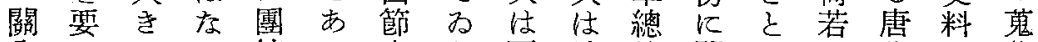
內しない結つ度た兩城管關め午代の集 $\therefore$ 支か兵た使を者傍管するをるの少史

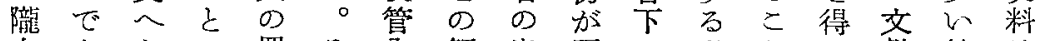

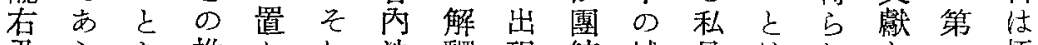
乃らな推かれ沙釋現結 城見はれと一極

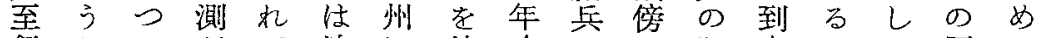

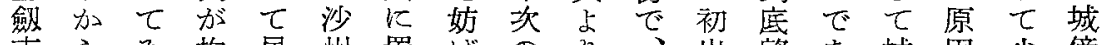
南らぬ抱居州置げのり、出望あ城因少浐 の、たかた出かは先十團史壳ら傍でく、の 邊そのれこ土れし後四結料可引にあ

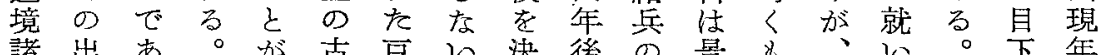

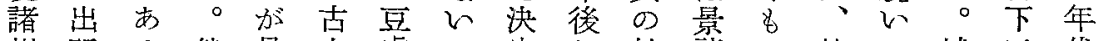

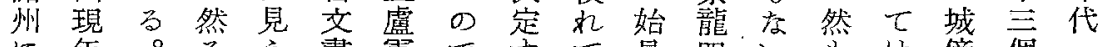

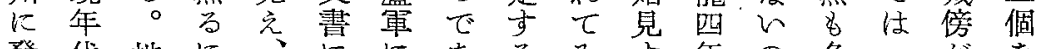

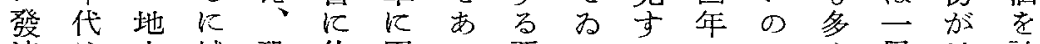
達は方城恐依霜る要るるるでく啳地計

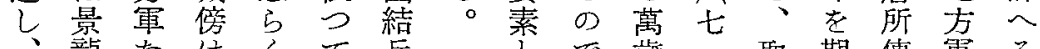
龍たはくてて兵方で歲 河をるそ閣初が衫あ通 ○敢待を的に

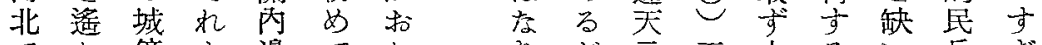
でか傍よ邊てか、りが元五大るい兵ぎ はにのり境知れ得、年月體こででな

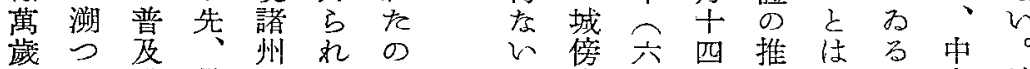

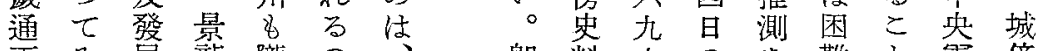

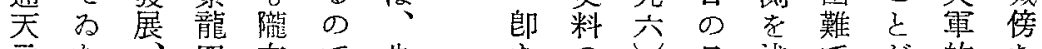
元た、四右で先占のさ而述で㤎的な 年に殊年道あに萬鬼に附心゙あ第民る

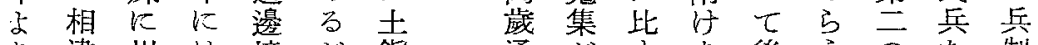
り違州は境が鎮通がすす後引のた制 團声鄉 朔 諸、兵極れる日。原るの 結る防方州別の元めば吐の方因團存

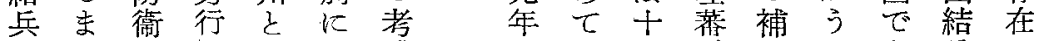
へ々上軍同元說的不四討正しあ兵に の。り總栐和飞團充年伐を方關氣 發思討管開郡聯結分のの侯立。係附

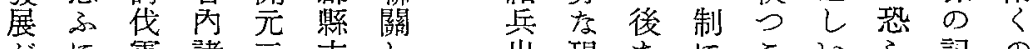

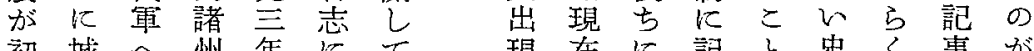

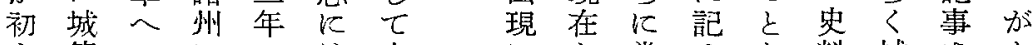

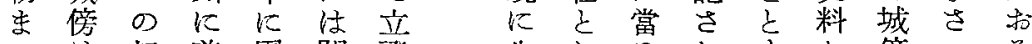

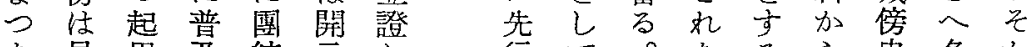
を早用及結元し 行て。方文央多加 兮く迄し兵七老此郎金。城料くつ

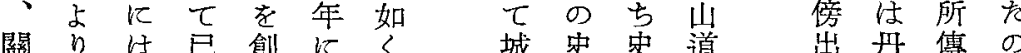
關りは已城史史道出乎傳の 內 河相 $k$ 置關、傍料料・現念を加 $\therefore$ 北罍邊し內開㤎の前のに失此 隴. の防た道元存始始方年搜しの 


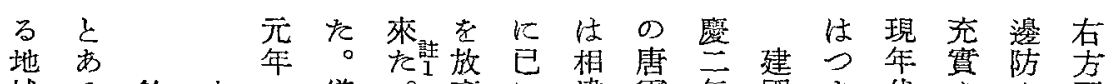
域方餘吐 儀。象に違雷年國を代をを面

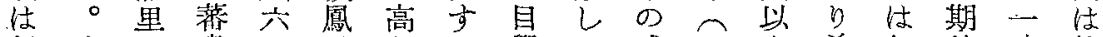

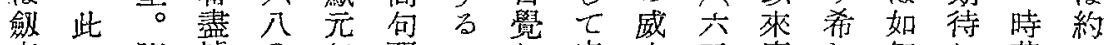

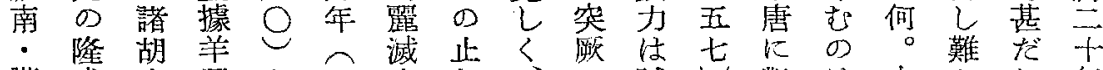

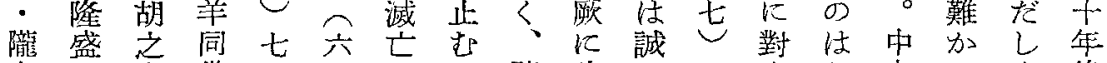
右は盛黨月十市症龍代に立初央つく後

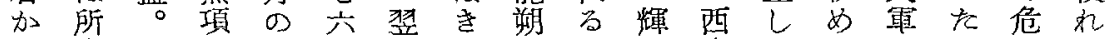

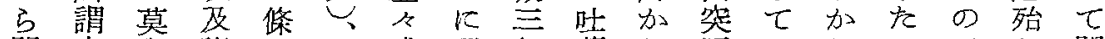

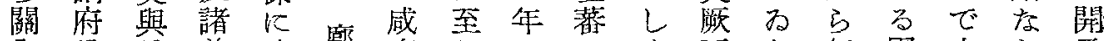

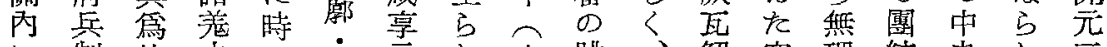

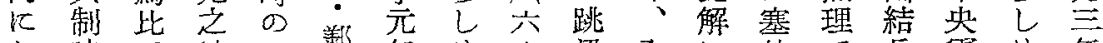
わ時。地洔等年め六梁全に多で兵電め年

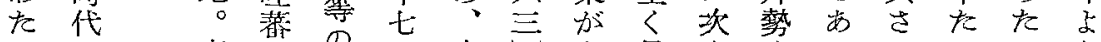

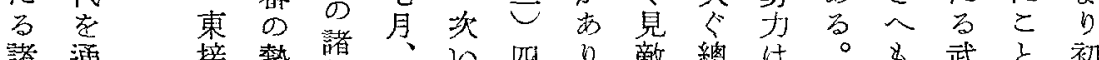

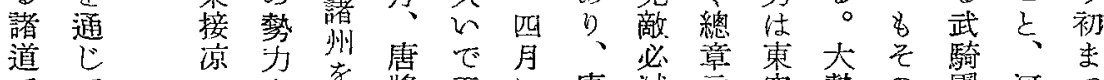
でて 妾獎五に唐隇元突勢の國河つ

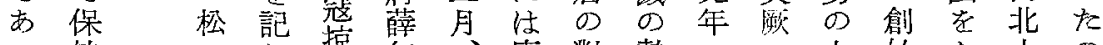
つ持 - ᄂ 掠仁、唐對勢 $・$ 上始和大の をせ茂七貴長の外它六薛汃年加本て

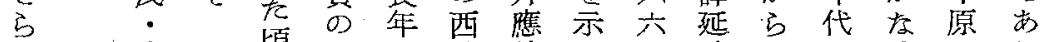

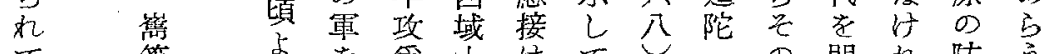

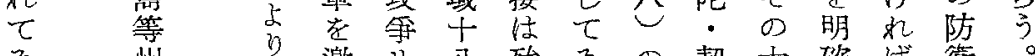

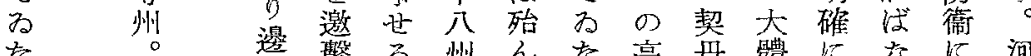

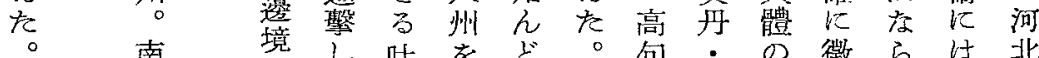

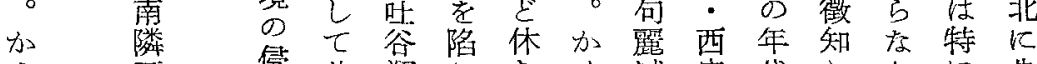

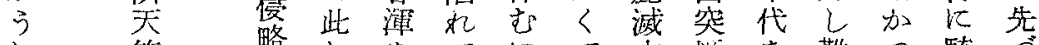

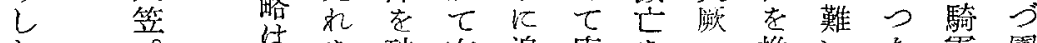

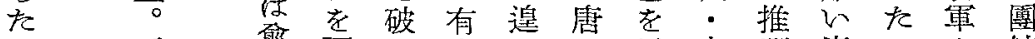

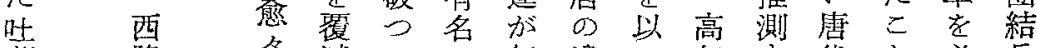

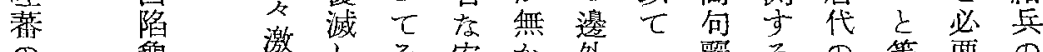

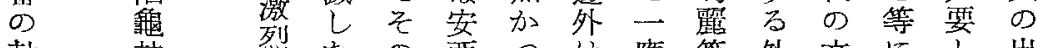

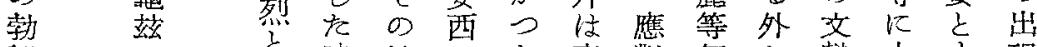

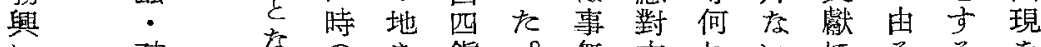

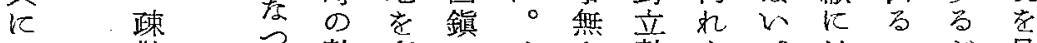

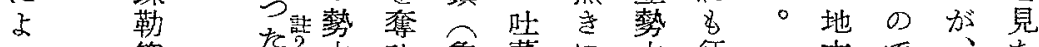
等 た2力田我蕃に方征方で、た て 四资は、茲の至の服電古地の

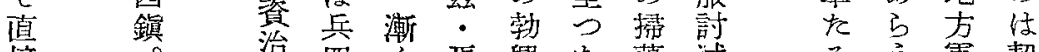
接治四々琵興た蕩滅方方電契

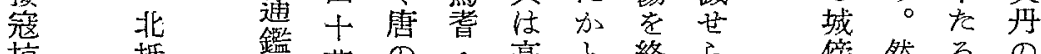

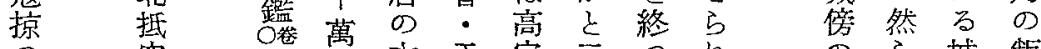

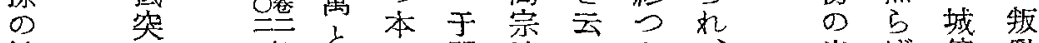

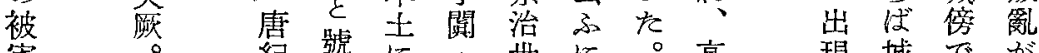
害。紀唬に・世地。高現城でが 地老草疏の宗年傍は市

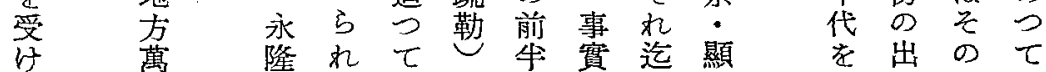




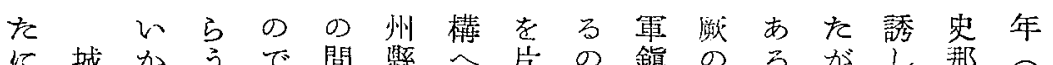

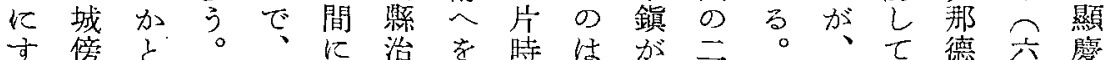

ぎ

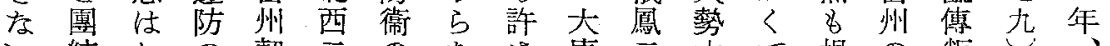

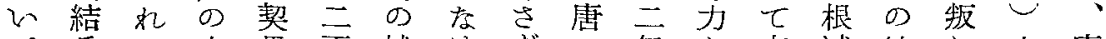
。兵る大开面城け ずの年々 高隇地し 六磨

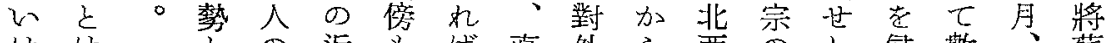

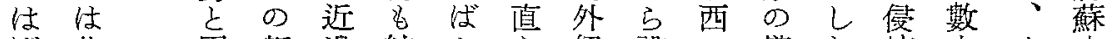

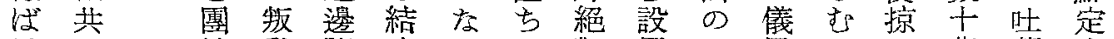

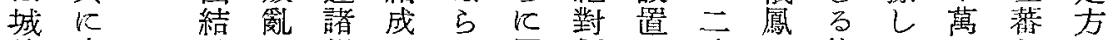

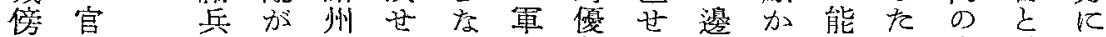
性兵創作に方分を勢 $ら$ に

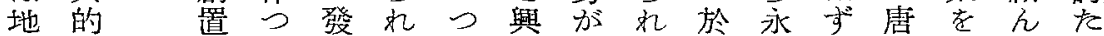

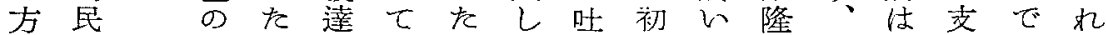

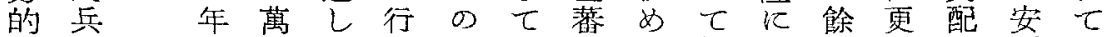

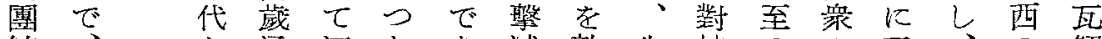
結々通河を市隇敵先㭙る心

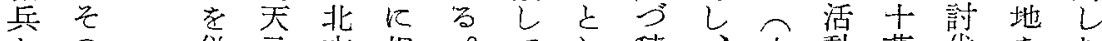
○ 併元方相。元し積、六動萬伐をを 茪制年面違汃居七石溜七佾のに優突

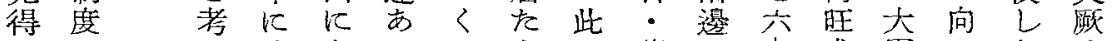

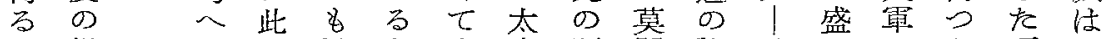

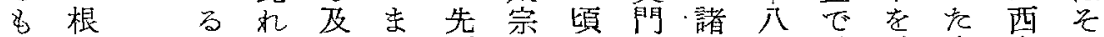

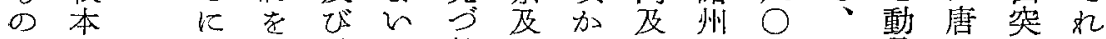

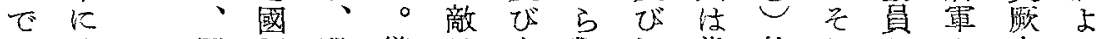
あは電軍恐儀地高對河常約れ乙去十り

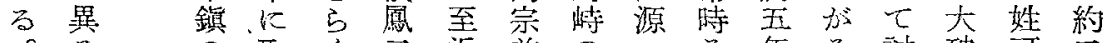

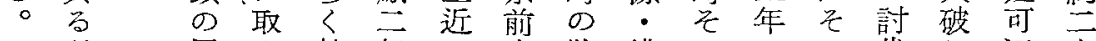
所置入敵 年

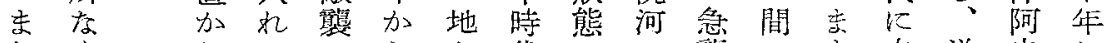

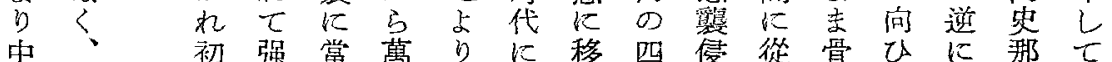

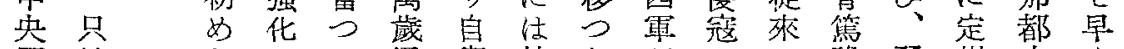

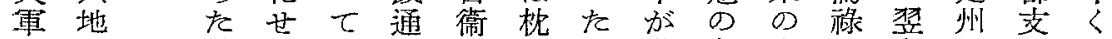

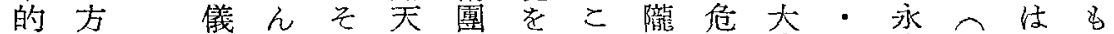

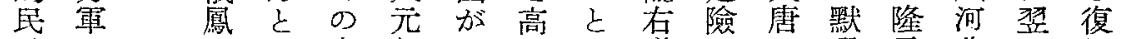

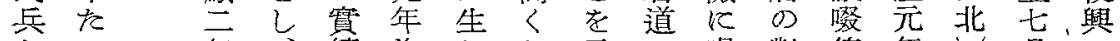
たる年、續迄光し示

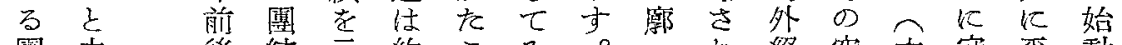
圊中後結示約

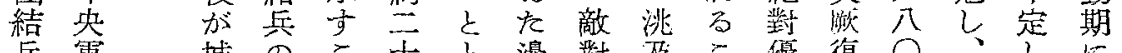

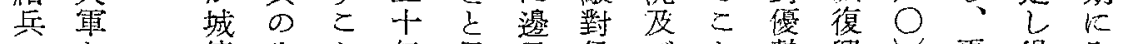
のた傍生と年思民侵びと等興し更得入

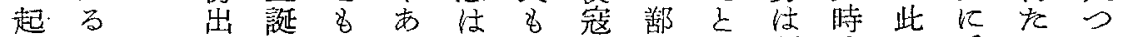

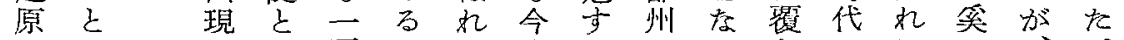

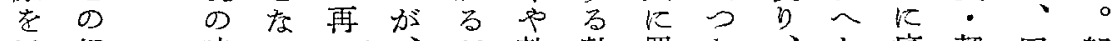
云相時つで、、が敵樊置た匀痛契同師

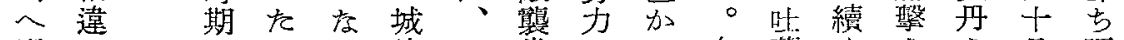
ばがでのか傍同常のれ有䈞くををを調 萬あ度でつ时至存七名: 0 加名、露 歳つ店あた此住の在な店突でへ焻阿元 
大整府兵制特代の䇥結兵に就いて

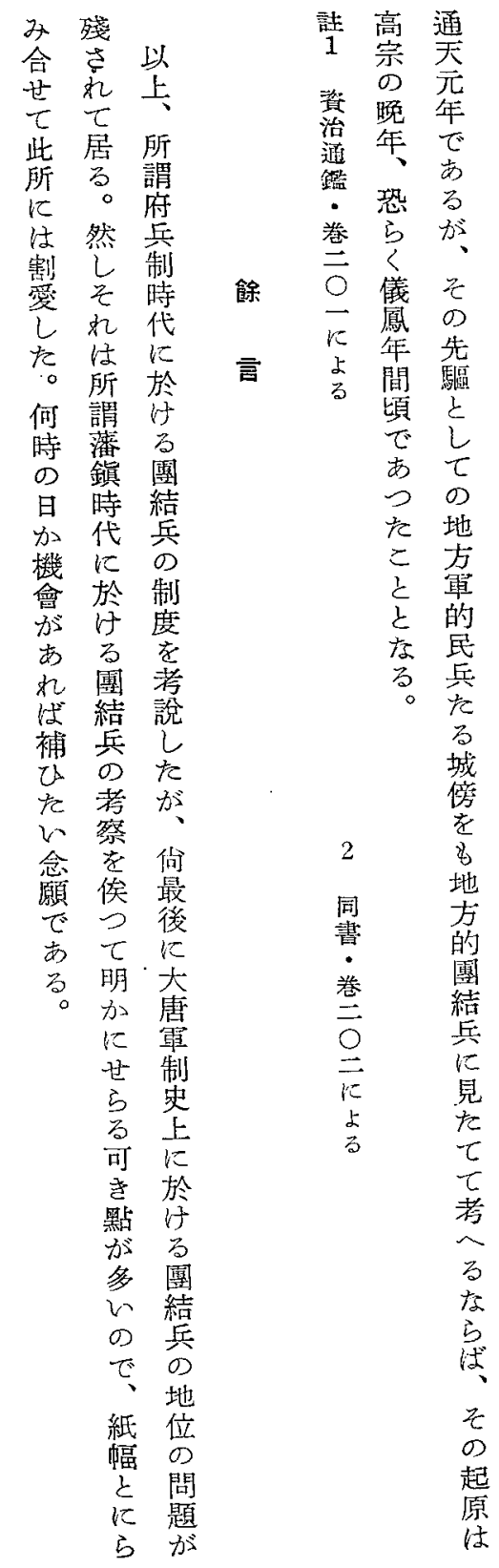




\title{
T'uan-chieh-ping \\ under the Fu-ping System of T'ang Dynasty
}

\author{
By Kaisaburo Hino
}

The T'ang Dynasty's military superiority to the northern barbarians was gradually undermined from around $680 \mathrm{~A}$. D. Northern races, such as T'u Chüeh, Ch'i-tan and T'u Fan, invaded the T'ang territory year after year. For self-defense, the inhabitants in the border regions organized a militia called Ta-chia-tzu-ti (大家子弟) (young men from the great families). Following this, provincial governors organized another militia for defense. This militia, called Ch'eng-pang-tzu-ti (城傍子弟) (young men beside the wal1), absorbed some Ta-chia-tza-ti in the neighborhood. To cope with the $\mathrm{Ch}^{\prime} \mathrm{i}-\tan$ rebellion in $696 \mathrm{~A}$. D., the central government expanded the militia in border regions into T'uan-chieh-ping (団結兵) (united soldiers). Ch'eng-pang-tzu-ti was also absorbed into this new organization. These "united soldiers" were enlisted as members of the regular army. They continued their argricultural work but received military training during the leisure season. In an emergency, they fought as part of the regular army and defended their native provinces. When they were in service, they were paid by the government. This system was adopted aiso in the border districts of Hopei, Shansi, Shensi and Szechwan provinces. As the military conscription system, known as "Fu-ping (府兵) system," gradually, disintegrated, the mercenary soldiers and the "united soldiers" formed the mainstays of the army. Around $740 \mathrm{~A}$. D.; about half of the 700,000 or 800,000 men in the army were "united soldiers." For a long period since then, in China, militia played its role as the troops auxiliary to hired troops, the latter being the regular army. The origin of the military system as such will be found in the "united soldiers," which made up the T'ang army together with Fu-ping. 